Rev. 1

Grand Junction Projects Office

Mixed-Waste Treatment Program

Packed-Bed Reactor/Silent-Discharge

Plasma Design Data Report

Revision 1

May 1996
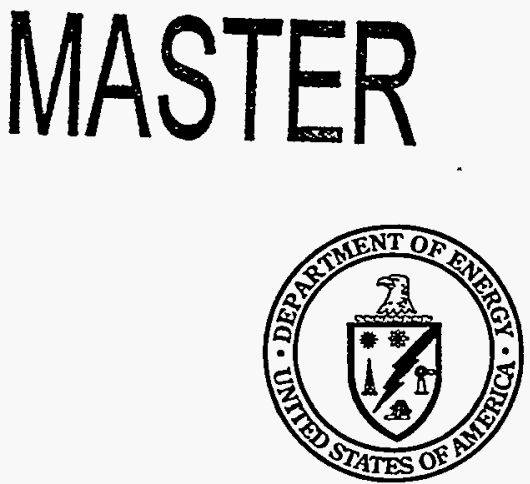

U.S. Department of Energy Grand Junction Projects Office

DISTAIBITION OF THIS DOCUMENT IS UNLMITED 



\title{
Packed-Bed Reactor/Silent-Discharge Plasma Design Data Report
}

Revised

May 1996

Prepared for

U.S. Department of Energy

Albuquerque Operations Office

Grand Junction Projects Office

\author{
Prepared by \\ Rust Geotech \\ Grand Junction, Colorado
}

Engineering Project Number ENG-430-0007-02-000

Engineering Document Number E0345401

Work Performed Under DOE Contract No. DE-AC04-94AL96907 
This page intentionally blank 


\section{DISCLAIMER}

Portions of this document may be illegible in electronic image products. Images are produced from the best available original document. 



\section{Signature Page}

Prepared by

Reviewed by $\frac{\text { Telm Many/h }}{\text { Ralph J. Mancik, P.E. }}$

Project Engineer

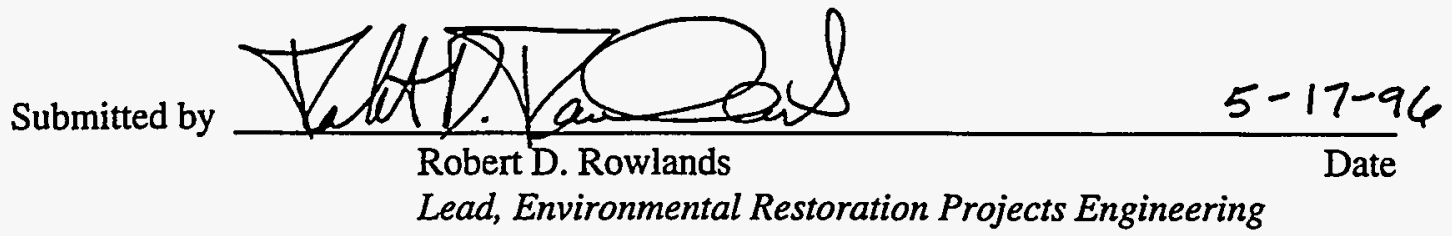

Approved by

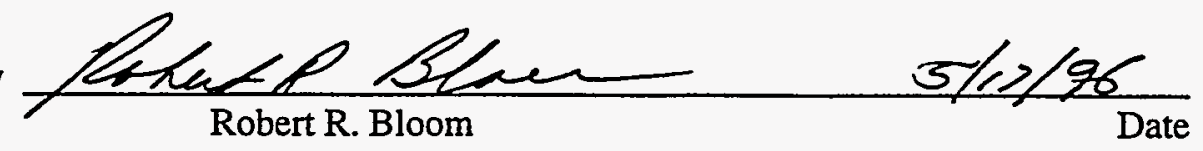

Project Manager

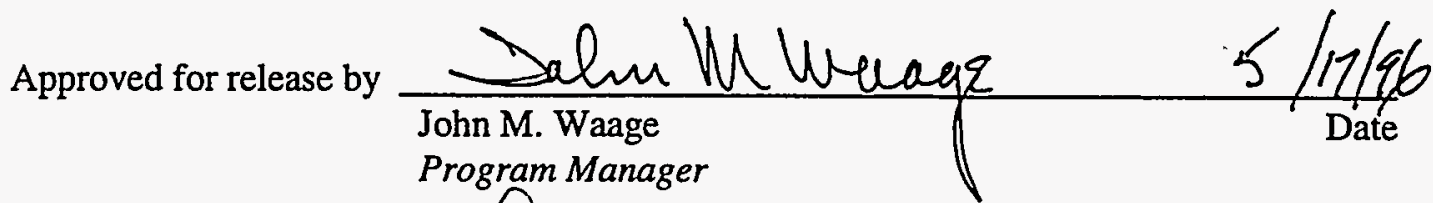

Approved for release by
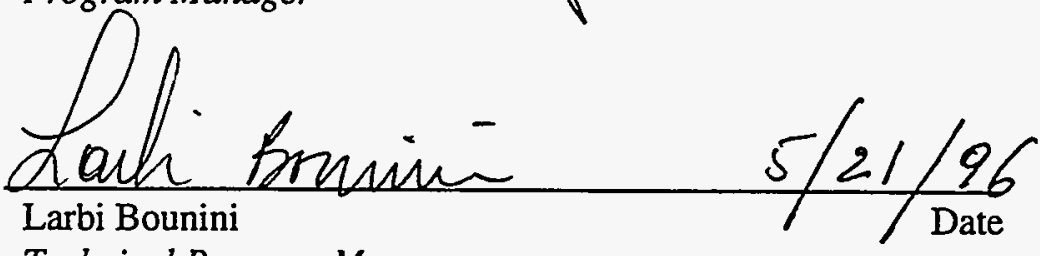

Larbi Bounini

Technical Program Manager 
This page intentionally blank 


\section{Contents}

Page

Abbreviations, Acronyms, and Initialisms $\ldots \ldots \ldots \ldots \ldots \ldots \ldots \ldots \ldots \ldots \ldots \ldots \ldots \ldots \ldots \ldots \ldots \ldots$

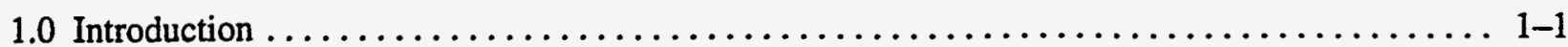

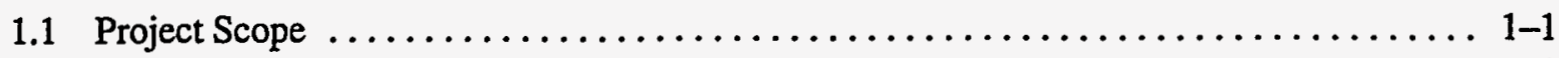

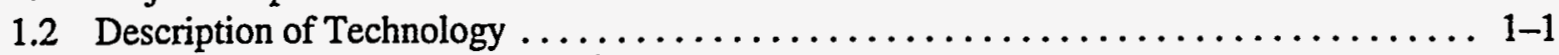

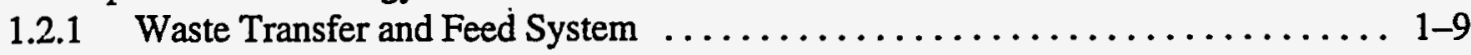

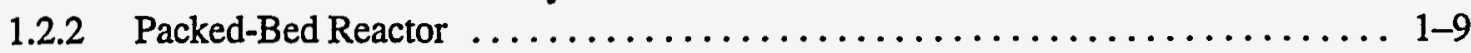

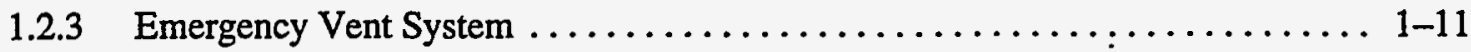

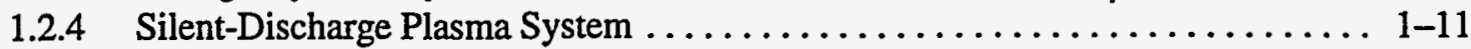

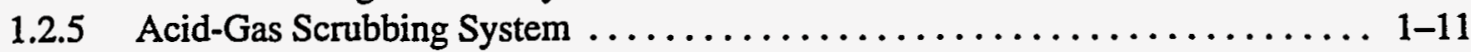

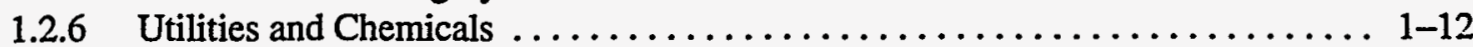

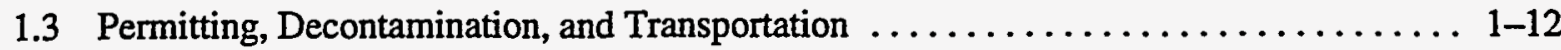

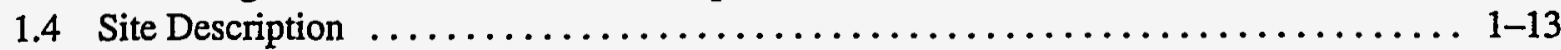

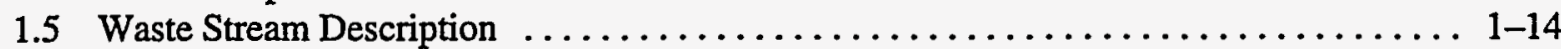

1.5.1 Los Alamos National Laboratory — LA-W $907 \ldots \ldots \ldots \ldots \ldots \ldots \ldots \ldots$

1.5.2 Los Alamos National Laboratory - LA-W $908 \ldots \ldots \ldots \ldots \ldots \ldots \ldots \ldots \ldots \ldots$

1.5.3 Sandia National Laboratory/New Mexico - SNL/NM-TG $11 \ldots \ldots \ldots \ldots \ldots$ 1-15

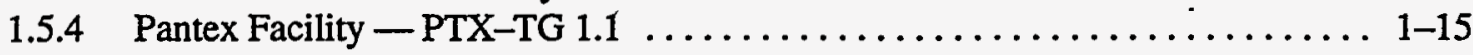

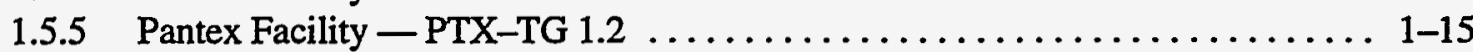

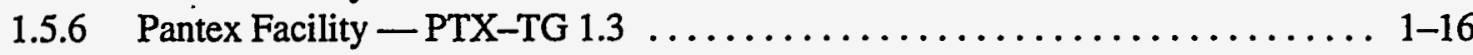

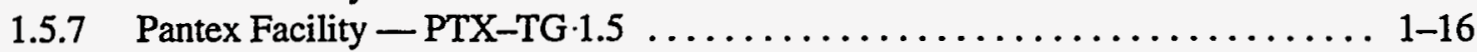

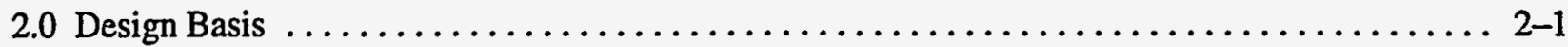

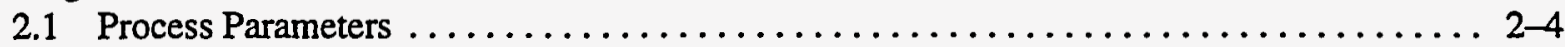

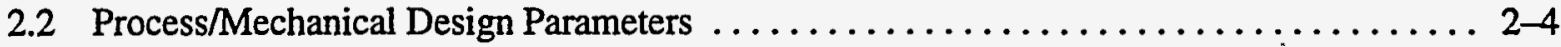

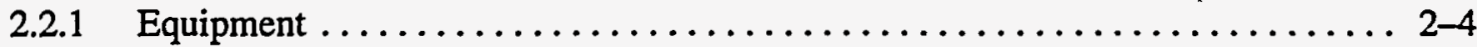

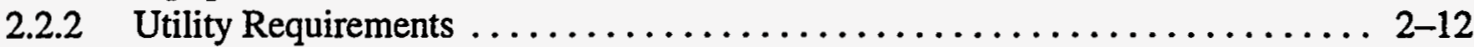

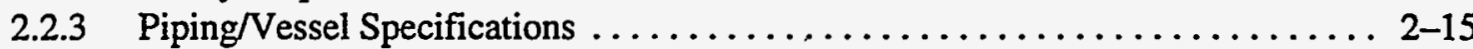

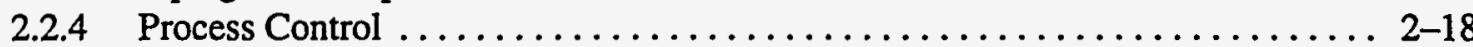

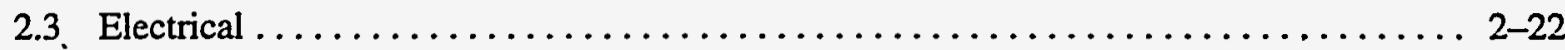

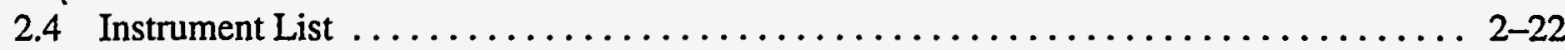

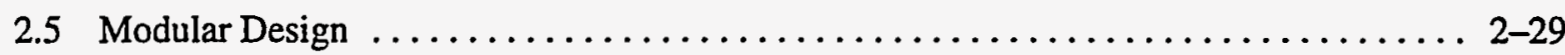

3.0 Feed Preparation Requirements $\ldots \ldots \ldots \ldots \ldots \ldots \ldots \ldots \ldots \ldots \ldots \ldots \ldots \ldots \ldots \ldots \ldots \ldots \ldots \ldots \ldots$

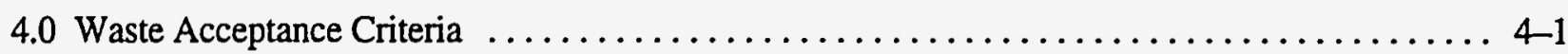

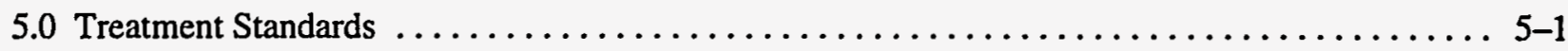

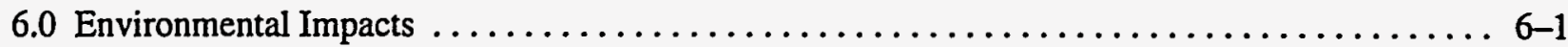

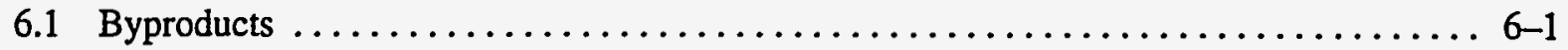

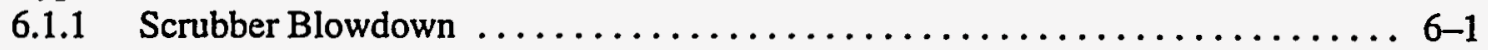

6.1 .2 Vent Emissions ............................... $6-3$

6.2 National Emission Standards for Hazardous Air Pollutants $\ldots \ldots \ldots \ldots \ldots \ldots \ldots \ldots$. 6 . 


\section{Contents (continued)}

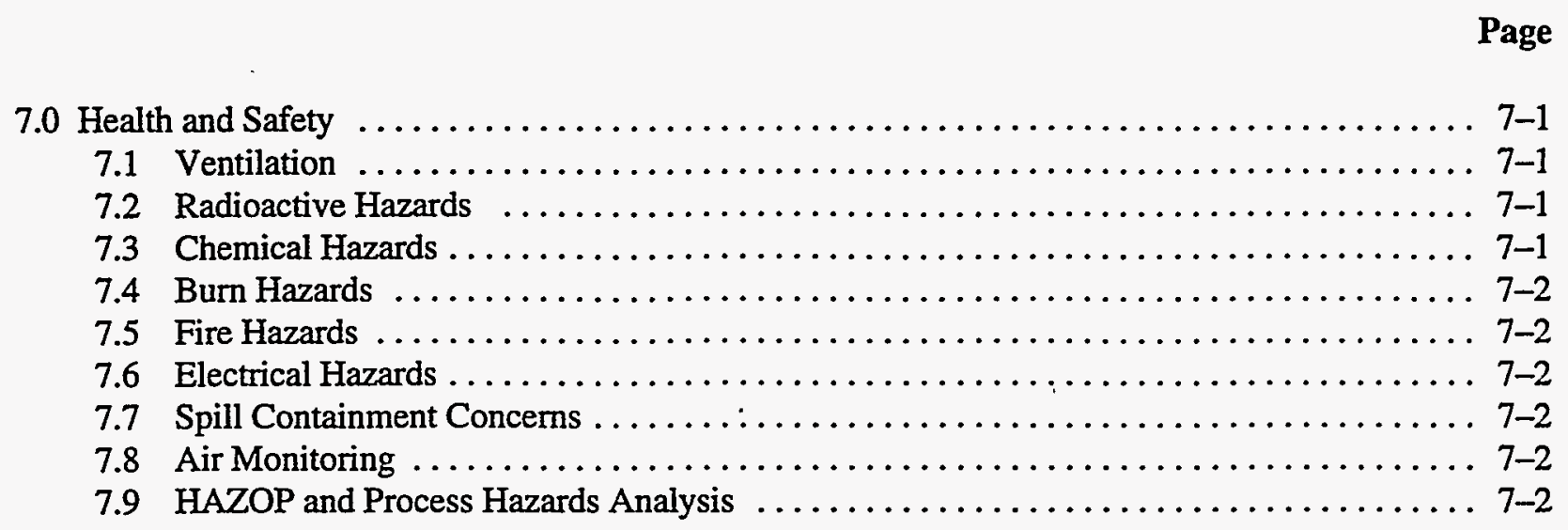

8.0 References $\ldots \ldots \ldots \ldots \ldots \ldots \ldots \ldots \ldots \ldots \ldots \ldots \ldots \ldots \ldots \ldots \ldots \ldots \ldots \ldots \ldots \ldots \ldots \ldots$

\section{Appendices}

Appendix A. PBR/SDP Process and Instrumentation Diagrams and Electrical Distribution . . . . . A-1 Appendix B. PBR/SDP Technology Development Reports $\ldots \ldots \ldots \ldots \ldots \ldots \ldots \ldots \ldots \ldots \ldots$ B-1 Appendix C. Resolution of PBR HAZOP Action Items $\ldots \ldots \ldots \ldots \ldots \ldots \ldots \ldots \ldots \ldots \ldots \ldots$ C-1

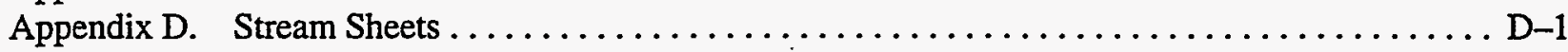

\section{Figures}

Figure $1-1$. PBR/SDP Process Flow Diagram $\ldots \ldots \ldots \ldots \ldots \ldots \ldots \ldots \ldots \ldots \ldots \ldots \ldots \ldots$

1-2. LANL Pilot PBR/SDP Unit Nozzle Design Schematic ............... 1-10

A-1. PBR/SDP P\&ID Drawing Symbology (Drawing E03557) . . . . . . . . . . . A -3

A-2. PBR/SDP P\&ID Feed System (Drawing E03456) $\ldots \ldots \ldots \ldots \ldots \ldots \ldots \ldots \ldots \ldots \ldots \ldots$

A-3. PBR/SDP P\&ID Packed-Bed Reactor (Drawing E03457) $\ldots \ldots \ldots \ldots \ldots \ldots \ldots \ldots$ A-7

A-4. PBR/SDP P\&ID Silent-Discharge Plasma (Drawing E03488) $\ldots \ldots \ldots \ldots \ldots \ldots \ldots$ A-9

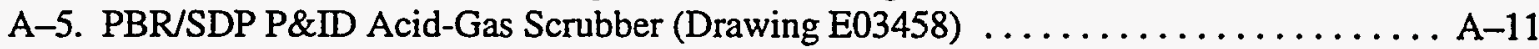

A-6. PBR/SDP P\&ID Offgas Handling System (Drawing E03489) . . . . . . . . . A-13

A-7. PBR/SDP P\&ID Utility/Chemical Addition (Drawing E03459) . . . . . . . . . A A-15

A-8. PBR/SDP Electrical Distribution (Drawing E03460) $\ldots \ldots \ldots \ldots \ldots \ldots \ldots \ldots \ldots \ldots \ldots \ldots \ldots$

\section{Tables}

Table 1-1. Material Balance Case 1: Heavy Hydrocarbon Oil $\left(\mathrm{C}_{20} \mathrm{H}_{42}\right) \ldots \ldots \ldots \ldots \ldots \ldots$

1-2. Material Balance Case 2: Chlorinated Aromatic Arachlor 1242) . . . . . . . . . 1-7

1-3. Material Balance Case 3: Aqueous Waste $(100 \%$ Water $) \ldots \ldots \ldots \ldots \ldots \ldots \ldots$

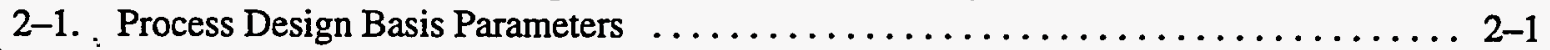

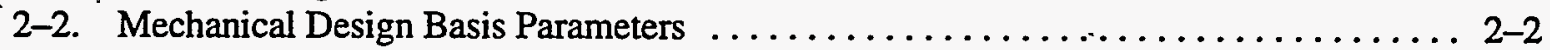

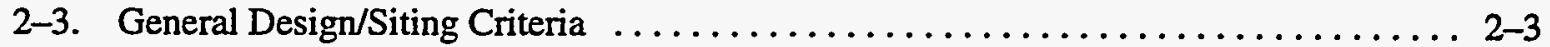

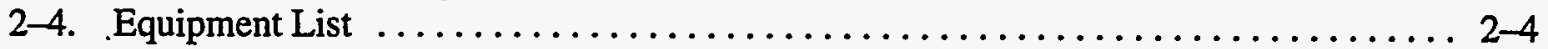




\section{Tables (continued)}

Page

Table 2-5. Electrical Requirements for PBR/SDP MTU .................... 2-13

2-6. Estimated Air Requirements for PBR/SDP MTU ................. 2-13

2-7. Piping Materials and Design Requirements for PBR/SDP MTU . . . . . . . 2-15

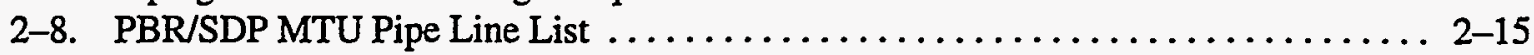

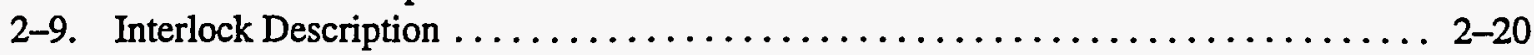

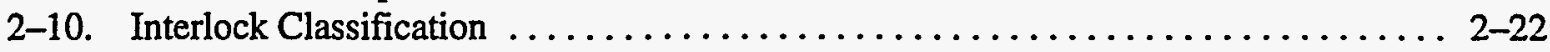

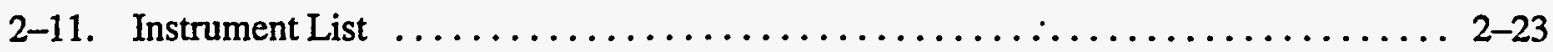

5-1. RCRA Hazardous-Waste Treatment Standards . . . . . . . . . . . . . . 5-1

6-1. Scrubber Blowdown from Treatment of Halogenated Organics ............ 6-2

6-2. Percentage of Total Water Removed in Scrubber Blowdown .............. 6-2

6-3. Carbon Monoxide Emissions from Operation of PBR/SDP MTU . . . . . . . . 6-4

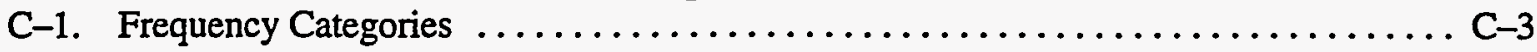

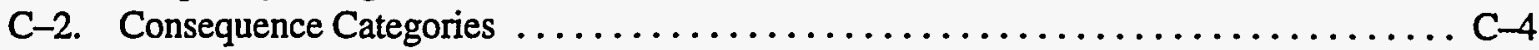

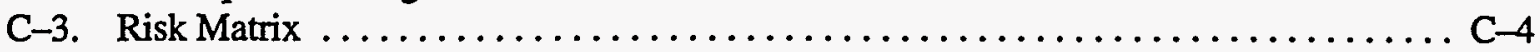

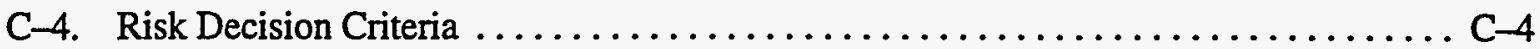

C-5. Resolution of PBR HAZOP Action Items $\ldots \ldots \ldots \ldots \ldots \ldots \ldots \ldots \ldots \ldots \ldots \ldots \ldots \ldots$

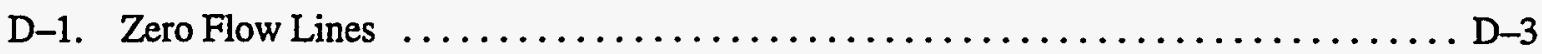

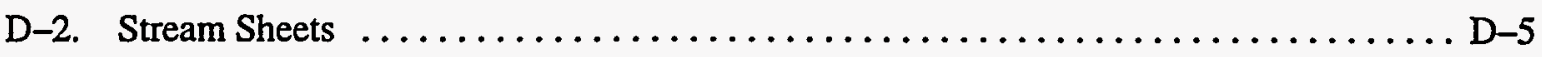


This page intentionally blank 


\section{Abbreviations, Acronyms, and Initialisms}

$\begin{array}{ll}\text { acfm } & \text { actual cubic feet per minute } \\ \mathrm{AL} & \text { Albuquerque Operations Office } \\ \mathrm{ANS} & \text { American Nuclear Society } \\ \mathrm{ANSI} & \text { American National Standards Institute } \\ \mathrm{ASME} & \text { American Society of Mechanical Engineers } \\ \mathrm{Btu} / \mathrm{h} & \text { British thermal unit(s) per hour } \\ \mathrm{cm}^{3} / \mathrm{min} & \text { cubic centimeter(s) per minute } \\ \mathrm{CFR} & \text { U.S. Code of Federal Regulations } \\ \mathrm{C}_{14} \mathrm{H}_{29} \mathrm{Cl} & \text { 1-chlorotetradecane } \\ \mathrm{C}_{20} \mathrm{H}_{42} & \text { n-eicosane } \\ \mathrm{CO} & \text { carbon monoxide } \\ \mathrm{CO} & \text { carbon dioxide } \\ \mathrm{COCl} & \text { phosgene } \\ \mathrm{cP} & \text { centipoise } \\ \mathrm{CWR} & \text { cooling water return } \\ \mathrm{CWS} & \text { cooling water supply } \\ \mathrm{DF} & \text { (radiological) decontamination factor } \\ \mathrm{DOE} & \text { U.S. Department of Energy } \\ \mathrm{DOT} & \text { U.S. Department of Transportation } \\ \mathrm{DDR} & \text { design data report } \\ \mathrm{EPA} & \text { U.S. Environmental Protection Agency } \\ \mathrm{FRP} & \text { fiberglass-reinforced plastic } \\ \mathrm{ft} & \text { foot (feet) } \\ \mathrm{ft} & \text { cubic foot (feet) } \\ \mathrm{gal} & \text { gallon(s) } \\ \mathrm{gal} / \mathrm{d} & \text { gallons per day } \\ \mathrm{gal} / \mathrm{h} & \text { gallons per hour } \\ \mathrm{gal} / \mathrm{min} & \text { gallons per minute } \\ \mathrm{GJPO} & \text { Grand Junction Projects Office } \\ \mathrm{HAZOP} & \text { hazards and operability } \\ \mathrm{h} / \mathrm{d} & \text { hours per day } \\ \mathrm{HCl} & \text { hydrogen chloride } \\ \mathrm{HEPA} & \text { high-efficiency particulate air } \\ \mathrm{HH} & \text { high-high } \\ \mathrm{hp} & \text { horsepower } \\ \mathrm{in} . & \text { inch(es) } \\ \mathrm{kW} & \text { kilowatt } \\ \mathrm{LANL} & \text { Los Alamos National Laboratory } \\ \mathrm{lb} & \text { pound(s) } \\ \mathrm{lb} / \mathrm{ft} & \text { pounds per cubic foot } \\ \mathrm{lb} / \mathrm{h} & \text { pounds per hour } \\ \mathrm{LDR} & \text { land disposal restriction } \\ \mathrm{LL} & \text { low-low } \\ \text { meter(s) } \\ \text { cubic meter(s) } \\ \end{array}$




\section{Abbreviations, Acronyms, and Initialisms (continued)}

\begin{tabular}{|c|c|}
\hline $\mathrm{mb}$ & millibar \\
\hline $\mathrm{mg} / \mathrm{kg}$ & milligrams per kilogram \\
\hline $\mathrm{mg} / \mathrm{L}$ & milligrams per liter \\
\hline $\mathrm{mmhos} / \mathrm{cm}$ & micro mhos per centimeter \\
\hline $\mathrm{mol} / \mathrm{h}$ & mols per hour \\
\hline $\mathrm{mrem} / \mathrm{h}$ & milliroentgen(s) per hour \\
\hline $\mathrm{mrem} / \mathrm{y}$ & milliroentgen(s) per year \\
\hline MTU & mobile treatment unit \\
\hline MWTP & Mixed-Waste Treatment Program \\
\hline $\mathrm{N}_{2}$ & nitrogen \\
\hline $\mathrm{NaCl}$ & sodium chloride \\
\hline $\mathrm{NaOH}$ & sodium hydroxide \\
\hline $\mathrm{O}_{2}$ & oxygen \\
\hline OSHA & Occupational Safety and Health Administration \\
\hline P\&ID & process and instrumentation diagram \\
\hline PBR & packed-bed reactor \\
\hline PCB & polychlorinated biphenyl \\
\hline PCDD & polychlorinated dibenzo-p-dioxins \\
\hline PCDF & polychlorinated dibenzofurans \\
\hline PLC & programmable logic controller \\
\hline PM10 & particulate material less than 10 microns \\
\hline POHC & principal organic hazardous constituent \\
\hline psi & pounds per square inch \\
\hline psia & pounds per square inch absolute \\
\hline psig & pounds per square inch gauge \\
\hline PTX & Pantex \\
\hline RCRA & Resource Conservation and Recovery Act \\
\hline scfm & standard cubic feet per minute \\
\hline SDP & silent-discharge plasma \\
\hline SNL/NM & Sandia National Laboratory/New Mexico \\
\hline TCE & trichloroethylene \\
\hline $\mathrm{TDH}$ & total developed head \\
\hline ton/y & ton(s) per year \\
\hline TSCA & Toxic Substance Control Act \\
\hline VAC & voltage, alternating current \\
\hline VE & value engineering \\
\hline VOC & volatile organic compound \\
\hline $\mathrm{v} / \mathrm{v}$ & volume per volume \\
\hline$w / w$ & weight per weight \\
\hline WWE & wastewater evaporator \\
\hline
\end{tabular}




\subsection{Introduction}

\subsection{Project Scope}

In 1992, Congress passed the Federal Facility Compliance Act requiring the U.S. Department of Energy (DOE) to treat and dispose of its mixed waste in accordance with Resource Conservation and Recovery Act (RCRA) land disposal restrictions (LDRs). The DOE Albuquerque Operations Office (AL) currently does not have adequate systems to treat the mixed wastes generated and stored at the nine DOE-AL sites. In response to the need for mixed-waste treatment capacity, DOE-AL organized a Treatment Selection Team under the Mixed-Waste Treatment Program (MWTP) to match mixed wastes with treatment options and develop a strategy for treatment of its mixed waste.

The strategy developed by the Treatment Selection Team, as described in the AL Mixed-Waste Treatment Plan (DOE 1994), is to use available off-site commercial treatment facilities for all wastes that can be successfully and cost-effectively treated by such facilities. Where no appropriate commercial treatment facilities exist, mobile treatment units (MTUs) would be developed to treat wastes at the sites where the wastes are generated. Treatment processes used for mixed waste must not only address the hazardous component (i.e., meet LDRs) but also must contain the radioactive component in a form that allows final disposal while protecting workers, the public, and the environment.

The Treatment Selection Team identified the packed-bed reactor/silent-discharge plasma (PBR/SDP) technology as potentially appropriate for treatment of organic and aqueous liquid and slurried mixed-waste streams. Los Alamos National Laboratory (LANL) has conducted a number of pilot tests with both the PBR and the SDP, individually and with the two units together, on a variety of surrogate organic wastes. Information obtained from the LANL pilot tests was used to determine the scope of applicability of the technology, and in the development of this design data report (DDR). Appendix B of this report lists a number of reports that present data and results of the LANL pilot tests.

DOE-AL assigned overall responsibility for development of the PBR/SDP to Sandia National Laboratory/New Mexico (SNL/NM). SNL/NM subsequently delegated responsibility for development of the DDR for the PBR/SDP MTU to the DOE Grand Junction Projects Office (GJPO). The scope of this report is to present basic design data for the PBR/SDP MTU, which will be used to prepare the detailed design of the MTU under a separate project. The PBR/SDP MTU represents a "second generation" of the technology, based on the design and operating parameters demonstrated at LANL, as reviewed and approved during a Value Engineering (VE) session on the PBR/SDP technology (Rust Geotech 1994).

\subsection{Description of Technology}

The Process Flow Diagram (Figure 1-1) gives a general overview of the major streams in the PBR/SDP process. PBR/SDP technology treats liquid nonaqueous and aqueous mixed-waste streams containing organic compounds and dissolved or suspended solids that may contain heavy metals and radionuclides. The PBR/SDP MTU combines the PBR and SDP technologies developed at LANL into a single, integrated process unit that will destroy hazardous organic compounds at overall destruction efficiencies of 99.9999 percent. The outlet streams from the process include the "blowdown" from the Acid-Gas Scrubber (equipment number S-300) containing sodium halide and sodium hydroxide, and the vent gas and oxidation products.

The mixed-waste feed is atomized and mixed with air (or a mixture of oxygen and inert gas) and enters the top of the PBR (R-100). The PBR consists of a hollow cylinder or pipe that is filled with an inert packing and externally heated. The packing is not catalytic and functions only to promote uniform heating and 
distribution of reactants. The temperature of the PBR is maintained between 600 and $1,050^{\circ} \mathrm{C}$ by controlling the external heaters and the waste feed and air rates. Based on data from the pilot PBR studies at LANL, at these temperatures, at least 99.99 percent of the organics are oxidized to form carbon dioxide, water vapor, and, when chlorinated compounds are treated, hydrogen chloride $(\mathrm{HCl})$. The organic concentration is kept below the lower explosive limit by addition of excess air, typically over 200 percent of the stoichiometric requirement, so that no flame is produced in the reactor.

The offgas from the PBR, at 600 to $1,050^{\circ} \mathrm{C}$, is cooled to approximately $500^{\circ} \mathrm{C}$ by passing it through a short section of packed bed that is unheated and uninsulated. To inhibit formation of polychlorinated dibenzo-p-dioxins (PCDD) and polychlorinated dibenzofurans (PCDF) in the PBR offgas, a quench is provided for rapid cooling of the offgas. However, minimizing quench water usage is desirable because most of the quench water will eventually be withdrawn as scrubber blowdown (see Section 6.1.1), which is a secondary waste from the process. The potential for formation of PCDD and PCDF exists whenever wastes containing organics and chlorine are treated, although yields are several orders of magnitude lower from feed material consisting of aliphatics than from feed consisting of aromatics (Gullett et al. 1994), so the quench will not be used for waste streams that do not contain chlorine. The offgas from the Quench Chamber $(E-110)$ is cooled to $120^{\circ} \mathrm{C}$ (the maximum operating temperature of the SDP) in a shell-andtube heat exchanger and filtered to remove solids and radionuclides before being introduced to the SDP. Use of the uninsulated section of the packed bed and the heat exchanger to remove as much heat as possible reduces quench water requirements, and concomitant generation of secondary waste, by 80 percent compared to quenching alone.

The SDP consists of pairs of electrodes that are shielded from the flowing gas by plates of a dielectric such as glass. Application of an alternating voltage to the electrodes at near-atmospheric pressure produces a potential that generates an instantaneous electric discharge, which in turn ionizes gas molecules (e.g., oxygen) to form free radicals. The unstable free radicals constitute a "cold plasma" that attacks organic molecules, producing carbon dioxide and water vapor. The action of the SDP in destroying residual organics increases the overall destruction efficiency of the combined PBR/SDP to 99.9999 percent.

The offgas from the SDP flows to the Acid-Gas Scrubber, a packed countercurrent scrubber in which $\mathrm{HCl}$ produced from oxidation of chlorinated organics is neutralized by reaction with a solution of sodium hydroxide forming a sodium chloride salt solution. Sodium hydroxide makeup is added to maintain the solution $\mathrm{pH}$, and the salt solution is blown down as needed to maintain the conductivity of the circulating liquid. The inlet gas to the Scrubber is above the boiling point of water, and the neutralization reaction also generates heat, so the Scrubber will vaporize water under most conditions. When this vaporization occurs, addition of makeup water will be necessary to maintain the required liquid level in the Scrubber.

The LANL PBR/SDP pilot unit was never tested on radioactive or mixed wastes, and partitioning of radionuclides as they pass through the process remains uncertain. Tests of the PBR pilot unit at LANL on surrogate waste streams that produced nonradioactive particulates indicated that over 99 percent of those particulates remained in the packed bed. For this DDR, it is assumed that all radionuclides (except tritium) will stay in the packed bed, which will have to be disposed of as radioactive waste at the end of treatment, or as often as necessary to keep radiation levels from exceeding regulatory limits. To remove any particulates that may pass through the PBR, the design includes a knockout section on the Quench Chamber below the reactor, as well as the PBR Offgas Filter (F-120) and the SDP Inlet HEPA Filters $(\mathrm{F}-130 \mathrm{~A}$ and $\mathrm{F}-130 \mathrm{~B})$ upstream of the SDP. Two stages of high efficiency particulate air (HEPA) filtration at this point should effectively remove all radionuclides from the offgas stream. Radionuclides removed at these points will not be mixed waste because 99.99 percent of the hazardous constituents will have been destroyed or converted to nonhazardous compounds in the PBR. 


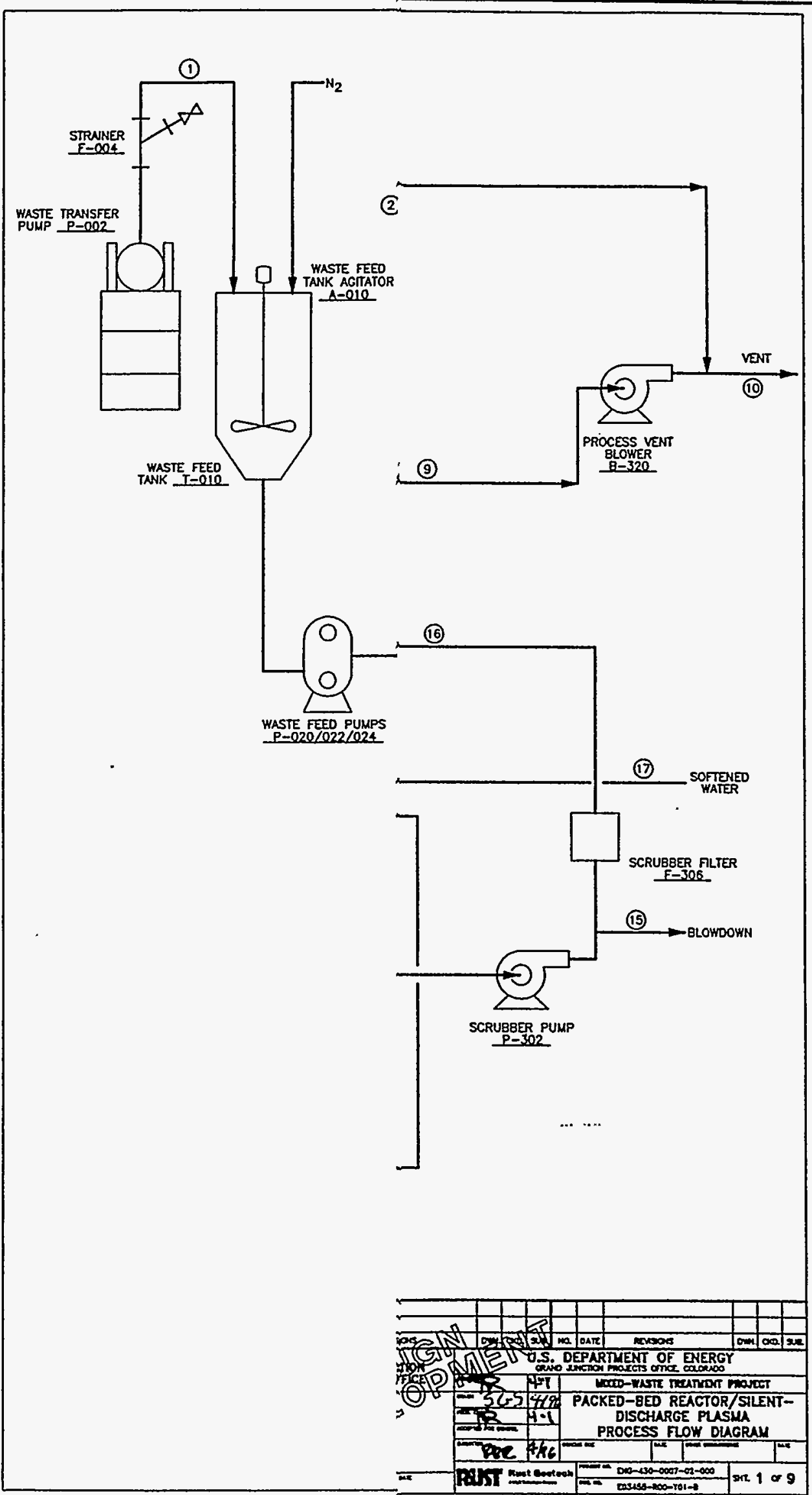




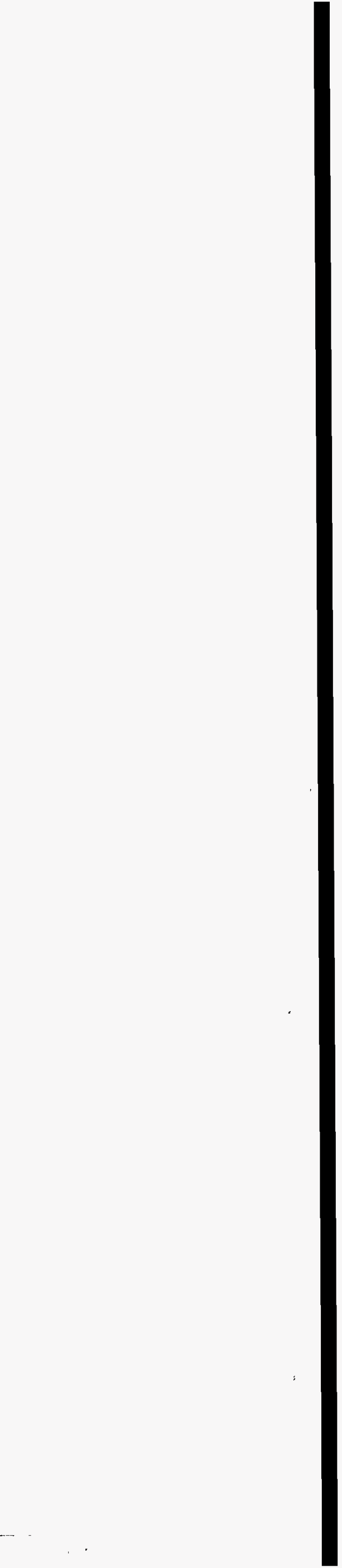


Testing of the PBR pilot unit at LANL on surrogate wastes demonstrated that when gas flow through the packed bed becomes restricted due to buildup of particulates in the packing, "steaming out" the packed bed is an effective means for removing these trapped particulates (LANL 1996a). This process may remove radionuclides as well, although, as mentioned above, this has never been tested. This DDR provides for periodic "steaming out" of the packed bed by feeding water to the PBR. This water will vaporize in the bed and can be recondensed in the PBR Offgas Cooler (E-112). If the resulting condensate is radioactive, it would have to be stored for later concentration using the wastewater evaporator (WWE), a secondary treatment process being developed separately by DOE-AL.

Tritiated organic compounds will be converted to tritiated water in the PBR/SDP MTU. When the AcidGas Scrubber is in operation, some of the tritiated water will be collected as scrubber blowdown, while the rest will be vented as vapor through the offgas system to the atmosphere. Treatment of nonhalogenated wastes will produce little or no scrubber blowdown; in fact, the scrubber may not be operated when nonhalogenated wastes are being treated. Thus, essentially all the tritiated water from treatment of such wastes will be vented. However, as much as 85 percent of the total water produced during treatment of highly halogenated wastes, such as polychlorinated biphenyls (PCBs), will be taken out in the Scrubber as blowdown. Scrubber blowdown containing tritiated water will have to be stored for later concentration using the WWE. Site permits will have to be reviewed to confirm that the venting of tritiated water vapor, both during operation of the PBR/SDP MTU and during WWE evaporation of scrubber blowdown, will not exceed discharge permits.

To ensure that equipment is designed for maximum flexibility, three types of waste streams were considered for the design, and the process design of each component is based on the "worst case" for that component. Material balances are provided in Tables 1-1 through 1-3 for the following three design cases.

Case 1: Treatment of 15 gallons per day (gal/d) of a heavy hydrocarbon oil. Properties of n-eicosane $\left(\mathrm{C}_{20} \mathrm{H}_{42}\right)$ were used. Oxidation of a hydrocarbon oil requires the highest amount of oxygen per weight of feed of any feed material, so this case sets the required air rate.

Case 2: Treatment of $15 \mathrm{gal} / \mathrm{d}$ of a chlorinated aromatic. Properties of Arachlor 1242 (a PCB containing approximately 42 percent chlorine) were used as a worst case for chlorine content. This case is the only one in which the Acid-Gas Scrubber is required, so it sets the maximum load for the water quench and the scrubbing system.

Case 3: Treatment of $75 \mathrm{gal} / \mathrm{d}$ of an aqueous stream with total organic concentration at parts-permillion levels. Properties of water were used as a worst case for an aqueous waste. Water has no heat of reaction, and the specified feed rate for this case is five times higher than for the other two cases, so this case establishes the maximum load for the PBR Heaters and the PBR Offgas Cooler.

An air rate of 40 standard cubic feet per minute (scfm) will provide a slightly endothermic system even for Case 1 and will ensure that the system is always operated in a nonexplosive regime. For simplicity, the air rate has been set at $40 \mathrm{scfm}$ for all three cases, as determined at the PBR/SDP VE session. During waste treatment using feeds of varying composition, the air rate can be adjusted to meet the characteristics of the actual waste streams. 
Table 1-1. Material Balance Case 1: Heavy Hydrocarbon Oil $\left(C_{20}\right)$

\begin{tabular}{|c|c|c|c|c|c|c|c|c|c|c|c|c|c|c|c|c|c|c|}
\hline Stream No. & $\begin{array}{c}\text { Wasto } \\
\text { Feed } \\
1\end{array}$ & $\begin{array}{c}\text { Waste } \\
2\end{array}$ & $\begin{array}{l}\text { Alr } \\
3\end{array}$ & $\begin{array}{c}\text { PBR } \\
\text { Outlet } \\
4 \quad .\end{array}$ & $\begin{array}{c}\text { Quench } \\
\text { Water } \\
5\end{array}$ & $\begin{array}{c}\text { Quench } \\
\text { Outlet } \\
6\end{array}$ & $\begin{array}{c}\text { SDP } \\
\text { Inlet } \\
7 \\
\end{array}$ & $\begin{array}{c}\text { SDP } \\
\text { Outlet } \\
8 \\
\end{array}$ & $\begin{array}{c}\text { Scrubber } \\
\text { Off Gas } \\
9\end{array}$ & $\begin{array}{c}\text { HEPA } \\
\text { Inlet } \\
10 \\
\end{array}$ & $\begin{array}{c}\text { Vent to } \\
\text { ATM } \\
11 \\
\end{array}$ & $\begin{array}{c}\text { CWS } \\
\text { to } \\
\text { Cooler } \\
12 \\
\end{array}$ & $\begin{array}{c}\text { CWh } \\
\text { from } \\
\text { Cooler } \\
13 \\
\end{array}$ & $\begin{array}{c}\mathrm{NaOH} \\
\text { Makeup } \\
14 \\
\end{array}$ & $\begin{array}{c}\text { Scrubber } \\
\text { Oullet } \\
15\end{array}$ & $\begin{array}{c}\text { Scrubber } \\
\text { Blowdown } \\
16 \\
\end{array}$ & $\begin{array}{l}\text { Scrubber } \\
\text { Circulation } \\
\text { Llquidd } \\
17\end{array}$ & $\begin{array}{c}\text { Scrubber } \\
\text { Makeup } \\
\text { Water } \\
18 \\
\end{array}$ \\
\hline$C_{20}$ & 4.34 & 4.34 & 0 & $4.34 E-04$ & 0 & 4.34E-04 & $4.34 E-04$ & $4.34 E-06$ & 4.34E-06 & 4.34E-06 & 0 & 0 & 0 & 0 & 0 & 0 & 0 & 0 \\
\hline $\mathrm{N}_{2}$ & 0 & 0 & 139.89 & 139.89 & 0 & 139.89 & 139.89 & 139.89 & 139.89 & 139.89 & 139.89 & 0 & 0 & 0 & 0 & 0 & 0 & 0 \\
\hline $\mathrm{O}_{2}$ & 0 & 0 & 42.48 & 27.47 & 0 & 27.47 & 27.47 & 27.47 & 27.47 & 27.47 & 27.47 & 0 & 0 & 0 & 0 & 0 & 0 & 0 \\
\hline $\mathrm{CO}_{2}$ & 0 & 0 & 0 & 13.53 & 0 & 13.53 & 13.53 & 13.53 & 13.53 & 13.53 & 13.53 & 0 & 0 & 0 & 0 & 0 & 0 & 0 \\
\hline $\mathrm{H}_{2} \mathrm{O}$ & 0 & 0 & 0 & 5.82 & 0 & 5.82 & 5.82 & 5.82 & 8.32 & 8.32 & 8.32 & 1,667 & 1,667 & 0.00 & 1.110 .16 & 0.00 & 1,112.66 & 2.51 \\
\hline $\mathrm{NaOH}$ & 0 & 0 & 0 & 0 & 0 & 0 & 0 & 0 & 0 & 0 & 0 & 0 & 0 & 0 & 0.00 & 0.00 & 0.00 & 0 \\
\hline $\mathrm{NaCl}$ & 0 & 0 & 0 & 0 & 0 & 0 & 0 & 0 & 0 & 0 & 0 & 0 & 0 & 0 & 0.00 & 0.00 & 0.00 & 0 \\
\hline Total Ibm & 4.34 & 4.34 & 182.37 & 186.71 & 0 & 186.71 & 186.71 & 186.71 & 189.22 & 189.22 & 189.22 & 1,667 & 1,667 & 0 & $1,110.16$ & 0.00 & $1,112.66$ & 2.51 \\
\hline Total moln & 0.015 & 0.015 & 6.321 & 6.483 & 0 & 6.483 & 6.483 & 6.483 & 6.622 & 6.622 & 6.622 & 92.533 & 92.533 & 0 & 61.62 & 0.00 & 61.76 & 0.139 \\
\hline Temp $\left({ }^{\circ} \mathrm{C}\right)$ & 25 & 25 & 25 & 1050 & - & 500 & 120 & 120.10 & 90.80 & 120 & 120 & 35.0 & 46.1 & - & 90.80 & - & 90.80 & 25 \\
\hline Pressure (psia) & 11.3 & 11.3 & 11.3 & 10.91 & - & 10.85 & 10.79 & 10.73 & 10.48 & 10.48 & 11.3 & 60.0 & 55.0 & - & 10.73 & - & 25.00 & 14.7 \\
\hline Density (Ib/fP) & 52.00 & 52.00 & 0.0566 & 0.0123 & - & 0.0209 & 0.0409 & 0.0407 & 0.0426 & 0.0394 & 0.0425 & 62.06 & 61.78 & - & 69.21 & - & 69.21 & 62.25 \\
\hline gavd & 15.00 & 15.00 & - & $\cdot$ & - & $\cdot$ & $\dot{-}$ & $\cdot$ & - & $\cdot$ & - & 4,823 & 4,844 & - & $2,879.87$ & - & $2,886.37$ & 7 \\
\hline
\end{tabular}

Heat Exchanger Dutles:

Rx Heater

12,388 Btu/h

PBR Olfgas Cooler

33,301 Btum

$3.6 \mathrm{~kW}$

Process Vent Heater

2,451 8tuh

$0.72 \mathrm{~kW}$ 
Table 1-2. Material Balance Case 2: Chlorinated Aromatic (Arachlor 1242)

\begin{tabular}{|c|c|c|c|c|c|c|c|c|c|c|c|c|c|c|c|c|c|c|}
\hline Stroam No. & $\begin{array}{c}\text { Waste } \\
\text { Foed } \\
1 \\
\end{array}$ & $\begin{array}{c}\text { Waste } \\
2 \\
\end{array}$ & $\begin{array}{c}\text { Air } \\
3\end{array}$ & $\begin{array}{c}\text { PBR } \\
\text { Outlet } \\
4\end{array}$ & $\begin{array}{c}\text { Quench } \\
\text { Water } \\
5\end{array}$ & $\begin{array}{c}\text { Quench } \\
\text { Outlet } \\
6\end{array}$ & $\begin{array}{c}\text { SDP } \\
\text { Inlet } \\
7\end{array}$ & $\begin{array}{c}\text { SDP } \\
\text { Outlet } \\
8\end{array}$ & $\begin{array}{c}\text { Scrubber } \\
\text { Off Gas } \\
9\end{array}$ & $\begin{array}{c}\text { HEPA } \\
\text { Inlet } \\
10\end{array}$ & $\begin{array}{c}\text { Vont to } \\
\text { ATH } \\
11\end{array}$ & $\begin{array}{c}\text { CWS } \\
\text { to } \\
\text { Cooler } \\
12\end{array}$ & $\begin{array}{l}\text { CWh } \\
\text { from } \\
\text { Cooler } \\
13 \\
\end{array}$ & $\begin{array}{c}\text { NaOH } \\
\text { Makeup } \\
14\end{array}$ & $\begin{array}{c}\text { Scrubber } \\
\text { Outlet } \\
15\end{array}$ & $\begin{array}{c}\text { Scrubber } \\
\text { Blowdown } \\
16 \\
\end{array}$ & $\begin{array}{c}\text { Scrubbor } \\
\text { Clrculation } \\
\text { Liquid } \\
17 \\
\end{array}$ & $\begin{array}{c}\text { Scrubber } \\
\text { Makoup } \\
\text { Water } \\
18 \\
\end{array}$ \\
\hline PCB 1242 & 7.23 & 7.23 & 0 & 7.23E-04 & 0 & $7.23 E-04$ & 7.23E-04 & $7.23 E-06$ & 7.23E-06 & 7.23E-06 & $0.00 E+00$ & 0 & 0 & 0 & 0 & 0 & 0 & 0 \\
\hline $\mathrm{N}_{2}$ & 0 & 0 & 139.89 & 139.89 & 0 & \begin{tabular}{|r|}
139.89 \\
\end{tabular} & \begin{tabular}{|r|}
139.89 \\
\end{tabular} & 139.89 & \begin{tabular}{|l|}
139.89 \\
\end{tabular} & \begin{tabular}{|r|}
139.89 \\
\end{tabular} & \begin{tabular}{|r|}
139.89 \\
\end{tabular} & 0 & 0 & 0 & 0 & 0 & 0 & $\underline{0}$ \\
\hline $\mathrm{O}_{2}$ & 0 & 0 & 42.48 & 30.80 & 0 & 30.80 & 30.80 & 30.80 & 30.80 & 30.80 & 30.80 & 0 & 0 & 0 & 0 & 0 & 0 & 0 \\
\hline $\mathrm{CO}_{2}$ & 0 & 0 & 0 & 14.82 & 0 & 14.82 & 14.82 & 14.82 & 14.82 & 14.82 & 14.82 & 0 & 0 & 0 & 0 & 0 & 0 & 0 \\
\hline $\mathrm{H}_{2} \mathrm{O}$ & 0 & 0 & 0 & 1.01 & 17.50 & 18.51 & 18.51 & 18.51 & 26.26 & 26.26 & 26.26 & 643 & 643 & 3.36 & 888.12 & 19.67 & 894.36 & 22.53 \\
\hline $\mathrm{HCl}$ & 0 & 0 & 0 & 3.07 & 0 & 3.07 & 3.07 & 3.07 & $3.07 E \cdot 03$ & 3.07E-03 & 0 & 0 & 0 & 0 & 0 & 0 & 0 & 0 \\
\hline $\mathrm{NaOH}$ & 0 & 0 & 0 & 0 & 0 & 0 & 0 & 0 & 0 & 0 & 0 & 0 & 0 & 3.36 & 0 & 0 & 3.36 & 0.00 \\
\hline $\mathrm{NaCl}$ & 0 & 0 & 0 & 0 & 0 & 0 & 0 & 0 & 0 & 0 & 0 & 0 & 0 & 0.00 & 222.03 & 4.92 & 217.11 & 0.00 \\
\hline Total Ibon & 7.23 & 7.23 & 182.37 & 189.60 & 17.50 & 207.10 & 207.10 & 207.10 & 211.78 & 211.78 & 211.77 & 643 & 643 & 6.73 & $1,110.16$ & 24.58 & 1,114.84 & 22.53 \\
\hline Tolal molh & 0.028 & 0.028 & 6.321 & 6.434 & 0.971 & 7.405 & 7.405 & 7.405 & 7.751 & 7.751 & 7.751 & 35.668 & 35.668 & 0.271 & 53.098 & 1.176 & 53.444 & 1.251 \\
\hline Temp $\left({ }^{\circ} \mathrm{C}\right)$ & 25 & 25 & 25 & 1050 & 25 & 250 & 120 & 120.07 & 90.80 & 120 & 120 & 35.0 & 46.1 & 25 & 90.80 & 90.80 & 90.80 & 25 \\
\hline Pressure (psia) & 11.3 & 11.3 & 11.3 & 10.91 & 10.91 & 10.85 & 10.79 & 10.73 & 10.48 & 10.48 & 11.3 & 60.0 & 55.0 & 14.7 & 10.73 & 25 & 25 & 14.7 \\
\hline Density $\left(\mathrm{b} / \mathrm{b} / \mathrm{t}^{3}\right)$ & 86.52 & 86.52 & 0.0566 & 0.0126 & 62.427 & 0.0300 & 0.0398 & 0.0395 & 0.0407 & 0.0377 & 0.0407 & 62.06 & 61.78 & 95.19 & 69.21 & 69.21 & 69.21 & 62.25 \\
\hline gavd & 15.00 & 15.00 & $\cdot$ &.$\cdot$ & 50.32 & $\cdot$ & $\cdot$ & - & - & - & - & 1,859 & 1,867 & 12.7 & 2,880 & 64 & 2,892 & 65 \\
\hline actm & - & - & 53.69 & 251.09 & - & 114.90 & 86.83 & 87.33 & 86.62 & 93.57 & 86.80 & - & - & - & - & - & - & - \\
\hline
\end{tabular}

Heat Exchanger Dutles:

Rx Heater

27,058 Btuh

$7.9 \mathrm{~kW}$

PBR Olfgas Cooler

12,836 Bium

Procoss Vent Heater

2,839 Bluh

$0.83 \mathrm{~kW}$ 
Table 1-3. Material Balance Case 3: Aqueous Waste (100\% water)

\begin{tabular}{|c|c|c|c|c|c|c|c|c|c|c|c|c|c|c|c|c|c|c|}
\hline Stream No. & $\begin{array}{c}\text { Waste } \\
\text { Feed } \\
1 \\
\end{array}$ & $\begin{array}{c}\text { Waste } \\
2\end{array}$ & $\begin{array}{c}\text { Air } \\
3 \\
\end{array}$ & $\begin{array}{c}\text { PBR } \\
\text { Outlet } \\
4 \\
\end{array}$ & $\begin{array}{c}\begin{array}{c}\text { Quench } \\
\text { Water } \\
5\end{array} \\
\end{array}$ & $\begin{array}{c}\text { Quench } \\
\text { Outlet } \\
6 \\
\end{array}$ & $\begin{array}{c}\text { SDP } \\
\text { Inlet } \\
7 \\
\end{array}$ & $\begin{array}{c}\text { SDP } \\
\text { Outlet } \\
8 \\
\end{array}$ & $\begin{array}{c}\text { Scrubber } \\
\text { OHf Gas } \\
9\end{array}$ & $\begin{array}{c}\text { HEPA } \\
\text { Inlet } \\
10 \\
\end{array}$ & $\begin{array}{c}\text { Vent to } \\
\text { ATM } \\
11\end{array}$ & $\begin{array}{c}\text { CWS } \\
\text { to } \\
\text { cooler } \\
12 \\
\end{array}$ & $\begin{array}{l}\text { CWh } \\
\text { from } \\
\text { Cooler } \\
13 \\
\end{array}$ & $\begin{array}{c}\mathrm{MaOH} \\
\text { Makeup } \\
14 \\
\end{array}$ & $\begin{array}{c}\text { Scrubber } \\
\text { Outlet } \\
15\end{array}$ & $\begin{array}{c}\text { Scrubber } \\
\text { Blowdown } \\
16 \\
\end{array}$ & $\begin{array}{c}\text { Clrculation } \\
\text { Liquid } \\
17\end{array}$ & $\begin{array}{c}\text { Scrubber } \\
\text { Makeup } \\
\text { Wator } \\
18 \\
\end{array}$ \\
\hline Water & 26.08 & 26.08 & 0 & 2.61E-03 & $0.00 \mathrm{E}+00$ & 2.61E-03 & 2.61E-03 & 2.61E-05 & 2.61E-05 & 2.61E-05 & 0 & 0 & 0 & 0 & 0 & 0 & 0 & 0 \\
\hline $\mathrm{N}_{2} \cdot$ & 0 & 0 & 139.89 & \begin{tabular}{|r|}
139.89 \\
\end{tabular} & 0 & \begin{tabular}{|r|}
139.89 \\
\end{tabular} & \begin{tabular}{|r|}
139.89 \\
\end{tabular} & \begin{tabular}{|l|}
139.89 \\
\end{tabular} & \begin{tabular}{|l|}
139.89 \\
\end{tabular} & \begin{tabular}{|l|}
139.89 \\
\end{tabular} & 139.89 & 0 & 0 & 0 & 0 & 0 & 0 & 0 \\
\hline $\mathrm{o}_{2}$ & 0 & 0 & $\begin{array}{r}-42.48 \\
\end{array}$ & 42.48 & 0 & 42.48 & 42.48 & 42.48 & 42.48 & 42.48 & 42.48 & 0 & 0 & 0 & 0 & 0 & 0 & 0 \\
\hline $\mathrm{CO}_{2}$ & 0 & 0 & 0.00 & 0.00 & 0 & 0 & 0 & 0 & 0 & 0 & 0 & 0 & 0 & 0 & 0 & 0 & 0 & $\underline{0}$ \\
\hline $\mathrm{H}_{2} \mathrm{O}$ & 0 & 0 & 0.00 & 26.08 & 0 & 26.08 & 26.08 & 26.08 & 29.09 & 29.09 & 29.09 & 2,006 & 2,006 & 0 & $1,110.16$ & 0.00 & $1,113.17$ & 3.01 \\
\hline $\mathrm{HCl}$ & 0 & 0 & 0 & 0 & 0 & 0 & 0 & 0 & 0 & 0 & 0 & 0 & 0 & 0 & 0.00 & 0.00 & 0.00 & 0 \\
\hline $\mathrm{NaOH}$ & 0 & 0 & 0 & 0 & 0 & 0 & 0 & 0 & 0 & 0 & 0 & 0 & 0 & 0 & 0.00 & 0.00 & 0.00 & 0 \\
\hline $\mathrm{NaCl}$ & 0 & 0 & 0 & 0 & 0 & 0 & 0 & 0 & 0 & 0 & 0 & 0 & 0 & 0 & 0.00 & 0.00 & 0.00 & 0 \\
\hline Tolal Ib/n & 26.08 & 26.08 & 182.37 & 208.45 & 0 & 208.45 & 208.45 & 208.45 & 211.46 & 211.46 & 211.46 & 2,006 & 2.006 & 0 & $1,110.16$ & 0.00 & $1,113.17$ & 3.01 \\
\hline Tolal moln & 1.448 & 1.448 & 6.321 & 7.769 & 0 & 7.769 & 7.769 & 7.769 & 7.936 & 7.936 & 7.936 & 111.344 & 111.344 & 0 & 61.624 & 0 & 61.791 & 0.167 \\
\hline Temp $\left({ }^{\circ} \mathrm{C}\right)$ & 25 & 25 & 25 & 1050 & - & 500 & 120 & 119.973 & 90.80 & 120 & 120 & 35.0 & 46.1 & 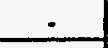 & 90.80 & - & 90.80 & 25 \\
\hline Pressure (psla) & 11.3 & 11.3 & 11.3 & 10.91 & . & 10.85 & 10.79 & 10.73 & 10.48 & 10.48 & 11.3 & 60.0 & 55.0 & - & 10.73 & $\cdot$ & 25 & 14.7 \\
\hline Density $\left(b / t^{3}\right)$ & 62.43 & 62.43 & 0.0566 & 0.0115 & $\therefore$ & 0.0195 & 0.0381 & 0.0379 & 0.0397 & 0.0368 & 0.0397 & 62.06 & 61.78 & - & 69.21 & - & 69.21 & 62.25 \\
\hline gavd & 75.00 & 75.00 & - & $\cdot$ & $\therefore$ & - & - & $\cdot$ & $\cdot$ & $\cdot$ & - & 5,803 & 5,829 & - & 2,880 & - & 2,888 & 9 \\
\hline $\mathrm{acfm}$ & - & - & 53.69 & 303.21 & - & 178.15 & 91.10 & 91.60 & 88.70 & 95.81 & 88.88 & - & $\cdot$ & 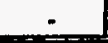 & - & $\therefore$ & - & - \\
\hline
\end{tabular}

Heat Exchanger Dulles:

Rx Heater

PBR Offgas Cooler

140,787 Btuh

0,071 Btwh

$41.3 \mathrm{~kW}$

Process Vent Healer

$0.87 \mathrm{~kW}$ 
Appendix A contains the piping and instrumentation diagrams (P\&IDs) for the MTU. The following description highlights the engineering features that make the PBR/SDP system a unique mixed-waste treatment process.

\subsubsection{Waste Transfer and Feed System}

Waste meeting the acceptance criteria (see Section 4.0) for the PBR/SDP process is received in standard shipping/storage containers (typically 55-gallon [gal] drums). The waste is pumped from the drum using a diaphragm-type Waste Transfer Pump ( $\mathrm{P}-002)$ through a Strainer (F-004) that removes coarse debris ( $1 / 8$ inch and larger in size) that would plug the spray nozzles. Material retained in F-004 will be washed and containerized. (Details of the washing and containerizing processes will be established in the detailed design.) After passing through F-004, the waste flows to the Waste Feed Tank (T-010), which is equipped with an Agitator ( $A-010)$ for blending compatible waste streams to provide a reasonably uniform feed to the PBR (R-100). The 175-gal working capacity of T-010 is sufficient to hold a 2-day supply of aqueous wastes at the design feed rate of $75 \mathrm{gal} / \mathrm{d}$ of aqueous waste, or a 10-day supply of organic wastes at the design feed rate of $15 \mathrm{gal} / \mathrm{d}$ of organic waste. Sodium hydroxide and sulfuric acid can be added to $\mathrm{T}-010$ for $\mathrm{pH}$ adjustment, and antifoam solution can be added as needed to prevent foaming in the tank. The Waste Feed Pumps (P-020, P-022, and P-024) transfer the waste from T-010 to $\mathrm{R}-100$ at a combined rate of up to $15 \mathrm{gal} / \mathrm{d}$ of organic waste, or up to $75 \mathrm{gal} / \mathrm{d}$ of aqueous waste.

Some degree of personnel protection will be required for the waste transfer operation during which the waste drum is opened and personnel are potentially exposed to hazardous fumes. In addition, some wastes may require pretreatment of some sort (e.g., addition of solvent to reduce viscosity). The minimal level of waste characterization at this time precludes specification of the level of protection and/or pretreatment required. Protection and pretreatment options will have to be evaluated during the detailed design process. Use of a drum unloading glovebox, similar in concept to that being built for the VAC*TRAX thermal desorption $\mathrm{MTU}^{1}$, may be the most practical solution for this function.

\subsubsection{Packed-Bed Reactor}

The PBR (R-100) is the primary reactor for the MTU because it is designed to destroy 99.99 percent of all hazardous organic compounds in the waste feed. This level of destruction has been demonstrated in the LANL surrogate tests on a wide variety of organic compounds.

Waste feed is introduced into $\mathrm{R}-100$ through atomizing nozzles where it is mixed with excess air. The nozzles use a design proven during the LANL pilot tests. Normal operating temperatures will be between 600 and $1,050^{\circ} \mathrm{C}$, depending on the principal organic constituent(s) of the waste being treated. Offgas from $\mathrm{R}-100$ will cool to approximately $500^{\circ} \mathrm{C}$ before being introduced into the Quench Chamber (E-110). Offgas from destruction of wastes containing chlorine will be quenched to $250^{\circ} \mathrm{C}$ by adding a water spray in E-110. To minimize generation of secondary wastes (see Section 6.1.1), the water spray is not used for other wastes, which will pass directly through E-110 and enter the PBR Offgas Cooler $(\mathrm{E}-112)$ at $500^{\circ} \mathrm{C}$. A schematic of the LANL nozzle design is shown in Figure 1-2. The top illustration is the nozzle design used in the LANL pilot PBR. The bottom illustration is an improved design (also by LANL) for enhanced atomization at higher liquid rates. LANL has suggested that the high-flow atomizing design might be better suited for the PBR/SDP MTU.

\footnotetext{
"The detailed design for the VAC"TRAX MTU has been developed by DOE-GJPO.
} 

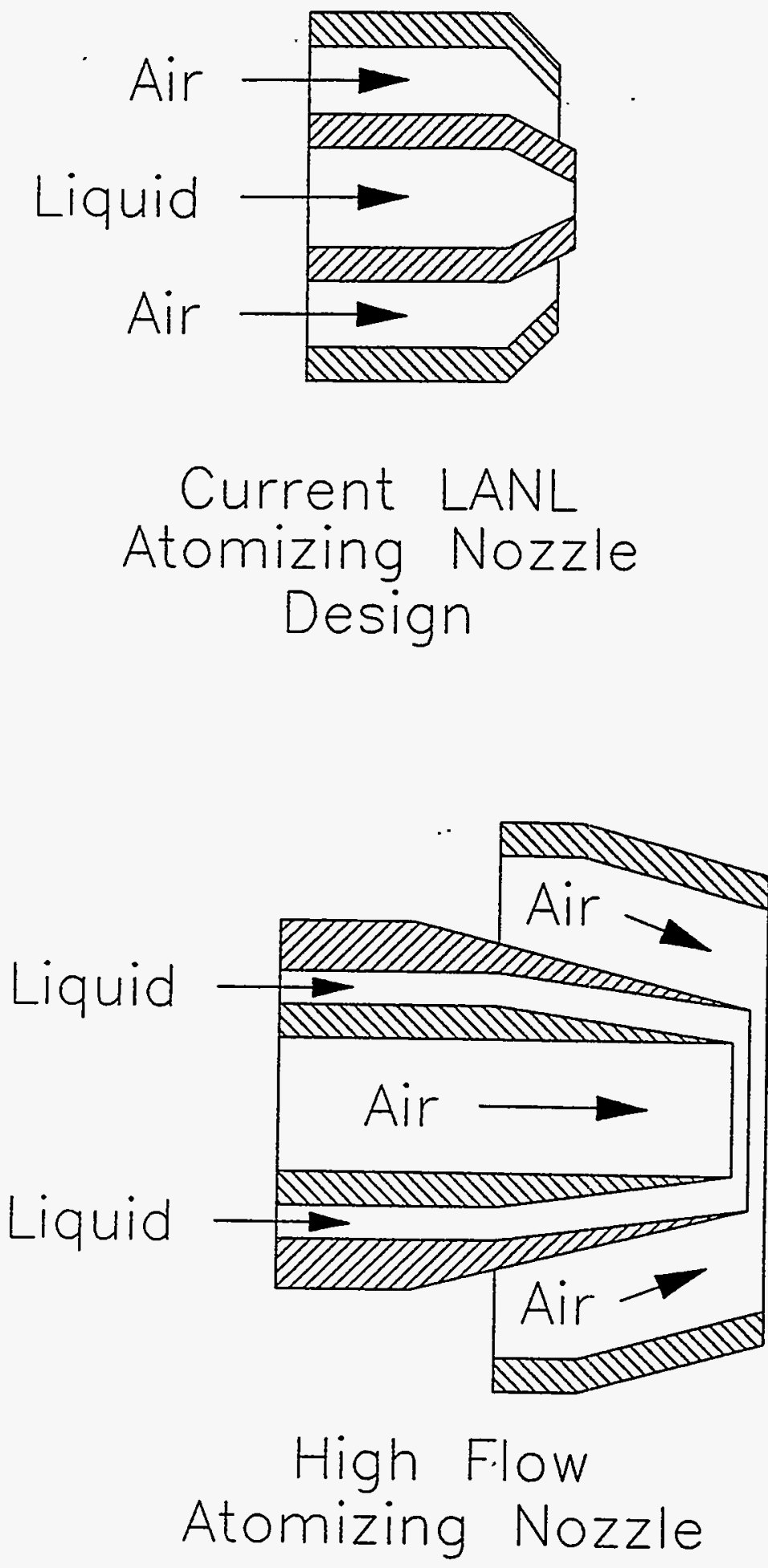

Figure 1-2. LANL Pilot PBR/SDP Unit Nozzle Design Schematic 


\subsubsection{Emergency Vent System}

In the event of a plug in the PBR offgas system, the PBR (R-100) pressure may rise rapidly as feed liquid is vaporized. An interlock will immediately stop feeds and shut off the heaters in the event of high pressure in R-100. However, the pressure will continue to rise for a time while residual liquid is vaporized and superheated by the hot packing. If the pressure continues to rise until it reaches the design pressure of R-100, it will be relieved through the Relief Rupture Disk (PSE 100-10). The gases vented through PSE 100-10 will contain both hazardous organics and radionuclides that must be collected to the extent possible. The emergency vent system is designed to capture these contaminants before they can be released to the atmosphere. Gases relieved through PSE 100-10 flow to the Relief Condenser (E-140) where condensable vapors are removed. The two-phase mixture then flows to the Relief Demister (T-142) where liquid droplets are removed and accumulated. The condensate can be drummed and "recycled" to the PBR. Noncondensable gases flow to the Relief HEPA Filter (F-144), which removes radionuclides, before venting the clean gas stream to the atmosphere. The design parameters for the emergency vent system will be established during detailed design after the design pressure of $R-100$ is determined.

\subsubsection{Silent-Discharge Plasma System}

The SDP (R-201, R-202, R-203, and R-204) serves as a second stage of organic destruction that will permit overall destruction efficiencies of 99.9999 percent or higher in the combined PBR/SDP unit. This level of destruction will be necessary to meet Toxic Substances Control Act (TSCA) regulations when TSCA-regulated wastes are treated, and also to meet treatment standards for a few select RCRA-regulated wastes (see Section 5.0). Offgas from the Quench Chamber (E-110) will be cooled to $120^{\circ} \mathrm{C}$ (the operating temperature of the SDP) in the PBR Offgas Cooler (E-112) to ensure that the SDP gas inlet temperature is above dewpoint. Coarse particulates such as fly ash will be removed in the PBR Offgas Filter (F-120), and radionuclides will be removed in the SDP Inlet HEPA Filters (F-130A and B). Use of two HEPA filters in series ensures that all radionuclides will be retained in the filter elements.

A "stand-alone" PBR is not designed to meet TSCA treatment standards for treatment of PCBs. Also, when wastes containing chlorine are treated, the potential for formation of PCDD/PCDF exists, as detailed in Section 1.2. Particulates collected in filters F-120, F-130A, and F-130B under these conditions may not meet treatment standards. Therefore, a bypass line has been provided so that when wastes containing PCBs or chlorine are being treated, the offgas from the PBR will bypass the filters initially and pass through the SDP directly. After treatment with the SDP is complete, the gas is routed through a second bypass line that passes it through the filters, removing radionuclides and residual particulates before passing on to the Acid-Gas Scrubber (S-300).

The SDP consists of a number of discrete, identical processing units, or cell banks, each containing 20 individual cells that are operated in parallel. The cell bank currently used at LANL is rated at a minimum of $10 \mathrm{scfm}$, so four cell banks will be required for the 40 -scfm design rate determined for the complete SDP module in the MTU. If fewer cell banks are available, the feed rate to the MTU must be reduced proportionately. The design and fabrication of the SDP units will be done by LANL and is not in the scope of this DDR.

\subsubsection{Acid-Gas Scrubbing System}

When the waste feed contains halogens, the offgas from the PBR/SDP will contain acid halogen gases such as $\mathrm{HCl}$, and also may contain trace amounts of phosgene $\left(\mathrm{COCl}_{2}\right)$. The purpose of the scrubbing system is to remove acid gases and particulates and destroy phosgene by reacting these compounds with a 
solution of sodium hydroxide and water that absorbs acid gases from the vapor stream and converts them to stable salts before exhausting the treated gas to the atmosphere.

In the Acid-Gas Scrubber (S-300), SDP offgas flows through a packed column where it contacts the sodium hydroxide solution, which is circulated by the Scrubber Pump (P-302). $\mathrm{HCl}$ in the gas stream reacts with sodium hydroxide to form sodium chloride salt. Sodium hydroxide makeup is added as required by the Sodium Hydroxide Addition Pump (P-304). The vapor exiting S-300 is exhausted to the atmosphere through the Process Vent Blower (B-320).

\subsubsection{Utilities and Chemicals}

Utilities for the PBR/SDP MTU include all of the following:

- Cooling water for the PBR Offgas Cooler (E-112) and the Relief Condenser (E-140), supplied by the Cooling Water Cooler (CW-400) in a closed-loop cooling water system.

- Compressed air for the PBR (R-100), the Waste Transfer Pump (P-002), and the Waste Feed Tank Agitator (A-010), supplied by the Air Compressor (AC-420).

- Nitrogen for inerting the vapor space in the Waste Feed Tank and for "sweeping" the pressure relief header, supplied by the Nitrogen Supply System $(\mathrm{N}-450)$.

- Process water used as makeup for the Quench Chamber (E-110) and the Acid-Gas Scrubber (S-300), supplied from site potable water systems and pretreated to remove dissolved salts in the Water Softener (W-310).

- $\quad$ Electricity, provided by the sites (480 VAC, 3-phase only), will be stepped down to lower voltage by transformers supplied with the MTU.

Details on expected consumption rates of these utilities are given in Section 2.2.1.

Chemicals for the PBR/SDP MTU include all of the following:

- Sodium hydroxide used in the Acid-Gas Scrubber (S-300) and the Waste Feed Tank (T-010), supplied by the Sodium Hydroxide Addition Pump (P-304) from 55-gal drums of concentrated (50 percent) sodium hydroxide.

- Sulfuric acid used in T-0i0 supplied by the Sulfuric Acid Addition Pump ( $\mathrm{P}-410)$ from 5-gal carboys of concentrated ( 98 percent) sulfuric acid.

- An antifoam agent for the Waste Feed Tank (T-010), supplied by the Antifoam Addition Pump (P-430).

\subsection{Permitting, Decontamination, and Transportation}

The PBR/SDP pilot unit has successfully passed technical review by the New Mexico Environmental Department, and has been well received in reviews with local public stakeholders. A RCRA research, development, and demonstration (RD\&D) permit, the first of its kind in the state of New Mexico, has been granted to the pilot unit for further technology development. 
The PBR/SDP MTU is expected to be permitted as a "miscellaneous unit" under Title 40, Part 264 of the U.S. Code of Federal Regulations (40 CFR 264), Subpart X, including the appropriate requirements of Subpart I through O and Subparts AA through CC of Part 264, Part 270, and Part 148. A miscellaneous unit must be located, designed, constructed, operated, maintained, and closed in a manner that will ensure protection of human health and the environment. Permits for miscellaneous units are to contain such terms and provisions as necessary to protect human health and the environment, including, but not limited to, as appropriate, design and operating requirements, detection and monitoring requirements, and requirements for responses to releases of hazardous waste or hazardous constituents from the unit.

The PBR/SDP MTU detailed design will address and demonstrate compliance with the Air Emissions Standards of CFR 264, Subparts AA (Process Vents), BB (Equipment Leaks), and CC (Tanks, Surface. Impoundments, and Containers). Since the design goal of the MTU is to reduce organic emissions by 99.99 percent or more, and the only process vent has already passed through the PBR (R-100), the SDP, and the Acid-Gas Scrubber (S-300), compliance with the Air Emissions Standards of Subpart AA should be easily demonstrated. All equipment in the MTU between the inlet to R-100 and the suction of the Process Vent Blower (B-320) normally operates at slightly below ambient pressure but above the threshold for exemption from the requirements of Subpart BB. The requirements of Subpart CC will apply only to the Waste Feed Tank ( $T-010)$, which is the only "container" in the MTU having a capacity of greater than $0.1 \mathrm{~m}^{3}$.

At the conclusion of treatment at each site, the PBR/SDP MTU must be decontaminated for transportation to the next site. Prior to transport, all liquids will be drained from the MTU so that it will be considered empty from a RCRA standpoint. Process chemicals such as sodium hydroxide and sulfuric acid will be obtained at each site rather than shipped with the MTU, and all unused chemicals will be added to that site's chemical inventory. It is possible that regulators in the various States where the MTU is targeted for use may have differing opinions regarding the regulatory status of unspent capture media (e.g., HEPA filters or activated carbon). This issue will have to be explored and resolved with the various State regulatory agencies during the permitting process.

Current plans call for the MTU to be shipped as "Radioactive Material-Excepted Package, Limited Quantity of Material." (One possible exception is the PBR itself and its packing, which may have to be removed and disposed of as radioactive waste [see Section 1.2.]). The requirements for shipment under this classification are specified by the U.S. Department of Transportation (DOT) in 49 CFR 173.423. Briefly, the regulations exempt the shipper from shipping documentation, certification, and marking and labeling requirements, other than certain limited and specific requirements called out in the regulation. To qualify for this classification, the internal contamination levels of the MTU must be below specified limits, which implies a knowledge of the type and amount of radioactivity present, as well as a design that provides the ability to assess the internal inventory of radionuclides. In addition, external radiation levels cannot exceed 0.5 millirem per hour $(\mathrm{mrem} / \mathrm{h})$ at any point on the surface; removable contamination on the external surface cannot exceed the limits given in 49 CFR 173.443; and the package must not contain more than 15 grams of uranium-235. The MTU must then be packaged in such a way that no radioactive materials will leak during shipment.

Details and information related to the design, construction, operation, and maintenance of the PBR/SDP MTU will be provided to DOE-AL, where the overall permitting effort will be coordinated to ensure reasonable consistency between each of the user sites. It is expected that the DOE-AL centralized permitting organization, in consultation with the States, will address these potential permitting issues and identify any other MTU closure requirements. Any additional requirements or recommendations from the permitting process will be incorporated, where appropriate, into the final MTU design and the technical 
information package prepared in support of the permitting process. The user sites will retain ultimate responsibility for negotiating the terms and conditions of the operating permits

\subsection{Site Description}

The PBR/SDP MTU is scheduled to be delivered to the following sites.

- $\quad$ LANL, Los Alamos, New Mexico.

- $\quad$ SNL/NM, Albuquerque, New Mexico.

- Pantex (PTX), Amarillo, Texas.

The MTU is designed to be housed in climate-controlled environments. However, the barometric pressure will have to be taken into account during design, and the ambient air temperature range will affect the design of any utility equipment that will be placed outdoors. The following are the ambient design conditions for the three designated sites.

\section{LANL}

- Elevation: 7,300 feet $(\mathrm{ft})(2,225$ meters [m]

- Average barometric pressure: 779 millibar (mb) (11.3 pounds per square inch absolute [psia])

- $\quad$ Seismic zone: $2 B$

- $\quad$ Reasonable maximum temperature: $88^{\circ} \mathrm{F}$

\section{SNL/NM}

- Elevation: $4,958 \mathrm{ft}(1,511 \mathrm{~m})$

- $\quad$ Average barometric pressure: $827 \mathrm{mb}(12.0 \mathrm{psia})$

- Seismic zone: $2 B$

- $\quad$ Reasonable maximum temperature: $98^{\circ} \mathrm{F}$

\section{PTX}

- $\quad$ Elevation: $3,600 \mathrm{ft}(1,097 \mathrm{~m})$

- $\quad$ Average barometric pressure: $889 \mathrm{mb}$ (12.9 psia)

- Seismic zone: 1

- Reasonable maximum temperature: $101^{\circ} \mathrm{F}$ 


\subsection{Waste Stream Description}

The waste streams described in the following paragraphs are being considered for treatment by the PBR/SDP MTU as of July 13, 1995. In all cases, the PBR/SDP technology will remove a corrosivity characteristic by neutralization, and will remove other hazardous characteristics by destruction of the hazardous organic compound(s). Radionuclides will concentrate in the packed bed, except for tritium, which will pass directly through the unit. Treatment time estimates are based on a feed rate of $15 \mathrm{gal} / \mathrm{d}$ (no aqueous wastes are included in the current inventory of wastes being considered for PBR/SDP treatment) with operation on a 24-hour basis, 7 days a week, and with an on-stream reliability factor of 75 percent.

\subsubsection{Los Alamos National Laboratory — LA-W 907}

LA-W 907 (formerly LANL-TG 18) is halogenated organic liquids, consisting primarily of spent solvents, laboratory chemicals, and bulk organics. The waste stream has designated RCRA waste codes D001, D002, D003, D007, D009, D018, D019, D022, D028, D029, D035, D043, F001, F002, F003, F005, U077, U080, U226, U227, U228, and U236. Suspected radionuclides are plutonium and uranium.

The current inventory of this waste stream, including an estimated 5-year generation of the waste, is 16.58 cubic meters $\left(\mathrm{m}^{3}\right)(4,380 \mathrm{gal})$. Total treatment time for this quantity of waste, including the 5-year generation, is estimated at 389 days.

\subsubsection{Los Alamos National Laboratory - LA-W 908}

LA-W 908 (formerly LANL-TG 19) is nonhalogenated organic liquids, consisting primarily of spent solvents, laboratory chemicals, and bulk organics. The waste stream has designated RCRA waste codes D001, D002, D003, D004, D007, D008, D009, D011, D018, D038, D040, F002, F003, F004, F005, U002, U019, U169, U188, U220, and U246. Suspected radionuclides are plutonium and uranium.

The current inventory of this waste stream, including an estimated 5-year generation of the waste, is $14.34 \mathrm{~m}^{3}(3,789 \mathrm{gal})$. Total treatment time for this quantity of waste, including the 5-year generation, is estimated at 337 days.

\subsubsection{Sandia National Laboratory/New Mexico - SNL/NM-TG 11}

SNL/NM-TG 11 is uncategorized organic liquids including vacuum pump oils, mixed nonhalogenated solvents, and a grinding sludge that contains trichloroethylene (TCE). The waste stream has designated RCRA waste codes D001, D006, D008, F002, F003, and F005. Suspected radionuclides are tritium and cesium-137.

The current inventory of this waste stream is $2.7 \mathrm{~m}^{3}(713 \mathrm{gal})$. Total treatment time for this quantity of waste is estimated at 63 days.

\subsubsection{Pantex Facility - PTX-TG 1.1}

PTX-TG 1.1 is uncategorized paint wastes from stripping and repainting parts in PTX Building 12-41. The waste stream consists primarily of epoxy paints, polyurethane enamels, out-of-date paints and solvents, and may include free water. The waste stream has designated RCRA waste codes D001, D006, D007, D008, and D009. Suspected radionuclides are tritium, thorium, and uranium. 
The current inventory of this waste stream, including an estimated 5-year generation of the waste, is $0.74 \mathrm{~m}^{3}$ (196 gal). Total treatment time for this quantity of waste, including the 5 -year generation, is estimated at 17 days.

\subsubsection{Pantex Facility - PTX-TG 1.2}

PTX-TG 1.2 is halogenated organic liquids, consisting primarily of chemicals that have been overpacked in drums, and bulked solvents, including dimethyl sulfoxide, which contains tritium in solution. The waste stream has designated RCRA waste codes D001, D003, D003, F001, F002, F003, F004, and F005A. Suspected radionuclides are tritium and uranium.

The current inventory of this waste stream, including an estimated 5-year generation of the waste, is $2.06 \mathrm{~m}^{3}$ (544 gal). Total treatment time for this quantity of waste, including the 5-year generation, is estimated at 48 days.

\subsubsection{Pantex Facility - PTX-TG 1.3}

PTX-TG 1.3 is nonhalogenated organic liquids, consisting of mercury-contaminated mineral oil from vacuum pump operation of environmental chambers. The designated RCRA waste code for this waste stream is D009 for mercury. Suspected radionuclides are tritium and possibly thorium and uranium-238.

The current inventory of this waste stream, including an estimated 5-year generation of the waste, is $1.55 \mathrm{~m}^{3}$ (410 gal). Total treatment time for this quantity of waste, including the 5-year generation, is estimated at 36 days.

\subsubsection{Pantex Facility - PTX-TG 1.5}

PTX-TG 1.5 is scintillation cocktails in glass vials loosely packed in vermiculite. The main component is pseudocumene, with some toluene and xylene in older vials. The waste stream has designated RCRA waste codes D001 and F003. Suspected radionuclides are tritium, thorium, and uranium at very low levels.

The current inventory of this waste stream is $0.72 \mathrm{~m}^{3}$ (190 gal). The analytical method in which the waste was generated is no longer used at Pantex, so the estimated 5-year generation of additional waste is zero. Total treatment time for this quantity of waste is estimated at 17 days. 


\subsection{Design Basis}

The process parameters and assumptions that form the basis for the PBR/SDP design are summarized in Table 2-1. Mechanical design basis parameters for each major equipment item are listed in Table 2-2, and general design and siting criteria are listed in Table 2-3. Whenever possible, experimental data have been used to develop the design basis and are referenced. The PBR/SDP MTU will be designed to meet the waste treatment standards discussed in Section 5.0 of this report.

Table 2-1. Process Design Basis Parameters

\begin{tabular}{|c|c|c|}
\hline Parameter & Value/Units & Comments \\
\hline PBR Feed Rate & $\begin{array}{l}15 \mathrm{gal} / \mathrm{d} \text { organic } \\
75 \mathrm{gal} / \mathrm{d} \text { aqueous }\end{array}$ & $\begin{array}{l}\text { Maximum flow rates determined during } \\
\text { PBR/SDP VE session. }\end{array}$ \\
\hline Air Rate & $40 \mathrm{sctm}$ & $\begin{array}{l}\text { As required to ensure endothermic } \\
\text { operation of PBR for all feeds. }\end{array}$ \\
\hline Solids in Feed & $\begin{array}{l}\text { Concentration unknown, not to exceed } \\
1 / 8 \text { in. in size when fed to PBR }\end{array}$ & $\begin{array}{l}\text { Wastes having solids larger than } \\
1 / 8 \text { in. will not be rejected; to avoid } \\
\text { plugging inlet nozzles, a strainer will } \\
\text { be provided in feed line. }\end{array}$ \\
\hline Waste Transfer Pump ( $P-002)$ & $15 \mathrm{gal} / \mathrm{min}$ nominal capacity & $\begin{array}{l}\text { To unload } 55 \text {-gal drum in } 5 \text { minutes or } \\
\text { less. }\end{array}$ \\
\hline Waste Feed Tank (T-010) & 175 gal working capacity & $\begin{array}{l}\text { At least a three-drum capacity for } \\
\text { optimum mixing. }\end{array}$ \\
\hline PBR Temperature & $\begin{array}{l}600-1,050^{\circ} \mathrm{C} \text { normal operating range } \\
1,200^{\circ} \mathrm{C} \text { equipment design maximum }\end{array}$ & $\begin{array}{l}\text { Use four zones of external electric } \\
\text { heat to attain operating temperature } \\
\text { based on aqueous waste feed. }\end{array}$ \\
\hline PBR Pressure & Atmospheric at inlet & Pressure drop to be determined. \\
\hline Quench Required? & $\begin{array}{l}\text { Only when wastes contain chlorine (to } \\
\text { minimize generation of secondary waste) }\end{array}$ & $\begin{array}{l}\text { Formation of dioxins and furans is not } \\
\text { significant except when chlorine is } \\
\text { present. }\end{array}$ \\
\hline Quench Temperature Profile & $\begin{array}{l}500^{\circ} \mathrm{C} \text { inlet } \\
250^{\circ} \mathrm{C} \text { outlet (normal) } \\
200^{\circ} \mathrm{C} \text { outlet (design capacity of quench) } \\
\end{array}$ & $\begin{array}{l}\text { Dioxinffuran formation occurs only } \\
\text { between } 400 \text { and } 250^{\circ} \mathrm{C} \\
\text { (Gullett et al. 1994) }\end{array}$ \\
\hline Particulate Removal from PBR Offgas & $\begin{array}{l}\text { One micron and larger particles at } 99 \% \\
\text { efficiency }\end{array}$ & HEPA not required at this point. \\
\hline SDP Inlet Temperature & $120^{\circ} \mathrm{C}$ & $\begin{array}{l}\text { To ensure that SDP operates above } \\
\text { dewpoint of water. }\end{array}$ \\
\hline SDP Feed Rate & $\begin{array}{l}10 \text { scfm per cell minimum, depending on } \\
\text { target compound }\end{array}$ & $\begin{array}{l}\text { Based on size of current SDP cells. } \\
\text { Can combine as many cells in parallel } \\
\text { as required for total MTU feed rate. }\end{array}$ \\
\hline Organic Destruction Efficiency (DRE) & $\begin{array}{l}99.99 \% \text { in PBR } \\
99.9999 \% \text { in combined PBR/SDP }\end{array}$ & $\begin{array}{l}\text { Confirmed in LANL tests on a wide } \\
\text { variety of organics. }\end{array}$ \\
\hline Acid-Gas Scrubber (S-300) & $\begin{array}{l}\text { Packed column, removes } 99.9 \% \text { of acid } \\
\text { gases from vapor stream, circulating } \\
\text { sodium hydroxide/sodium chloride } \\
\text { solution up to } 20 \text { percent, } \mathrm{pH}=6-8\end{array}$ & $\begin{array}{l}\text { Slightly acidic for maximum } \\
\text { destruction of } \mathrm{COCl}_{2} \text { with negligible } \\
\text { absorption of } \mathrm{CO}_{2} \text {. }\end{array}$ \\
\hline MTU Operablity & $24 \mathrm{~h} / \mathrm{d}$ & $75 \%$ stream factor. \\
\hline
\end{tabular}


Table 2-2. Mechanical Design Basis Parameters

\begin{tabular}{|c|c|c|}
\hline Parameter & Value/Units & Comments \\
\hline Waste Feed Tank (T-010) & Design pressure: $50 \mathrm{psig}$ at $300^{\circ} \mathrm{F}$ & $\begin{array}{l}\text { To allow pressure buildup when filling tank } \\
\text { while PBR is out of service. }\end{array}$ \\
\hline PBR (R-100) & $\begin{array}{l}\text { Design pressure: } 10 \mathrm{psig} / 1 \mathrm{psi} \text { vacuum at } \\
1,200^{\circ} \mathrm{C} \\
\text { Packing is } 1 / 2 \text { in. and } 3 / 16 \text { in. alumina balls }\end{array}$ & $\begin{array}{l}\text { Design pressure to be confirmed during } \\
\text { detail design } \\
\text { Heaters to have internal skin } \\
\text { over-temperature protection. }\end{array}$ \\
\hline Quench Chamber (E-110) & $\begin{array}{l}\text { Design pressure: } 10 \mathrm{psig} / 1 \mathrm{psi} \text { vacuum at } \\
1,200^{\circ} \mathrm{C}\end{array}$ & $\begin{array}{l}\text { Allow } 6 \text {-in. section below gas outlet for solids } \\
\text { disengagement. }\end{array}$ \\
\hline PBR Off-gas Cooler (E-112) & $\begin{array}{l}\text { Design pressure: } 15 \text { psig (shell and tubes) } \\
\text { at } 600^{\circ} \mathrm{C}\end{array}$ & $\begin{array}{l}\text { Size both for cooling load and condensing } \\
\text { load during "steam-out" (see text). }\end{array}$ \\
\hline $\begin{array}{l}\text { SDP Inlet HEPA Filters } \\
\text { (F-130AB) }\end{array}$ & $\begin{array}{l}\text { Design flow } 90 \text { actual } \mathrm{ft}^{3} / \mathrm{min} \text { (acfm) at } 1 \mathrm{psi} \\
\text { vacuum }\end{array}$ & \\
\hline $\begin{array}{l}\text { SDP (R-201, R-202, R-203, } \\
R-204)\end{array}$ & Design and fabrication by LANL & $\begin{array}{l}\text { Four cell banks each having } 10 \mathrm{scfm} \\
\text { capability. }\end{array}$ \\
\hline Acid-Gas Scrubber (S-300) & $\begin{array}{l}\text { Design for } 3 \text { psig at } 300^{\circ} \mathrm{F} \text {, } \\
\text { pH range 2-12; packing of Intalox saddles } \\
\text { or equivalent, include demister section at } \\
\text { vapor outlet }\end{array}$ & $\begin{array}{l}\text { Wide pH range for maximum corrosion } \\
\text { protection. }\end{array}$ \\
\hline Scrubber Pump (P-302) & $\begin{array}{l}2 \mathrm{gal} / \mathrm{min} \text { at } 30-\mathrm{ft} \text {. TDH, design for } \\
\mathrm{pH} \text { range } 2-12\end{array}$ & $\begin{array}{l}\text { Wide } \mathrm{pH} \text { range for maximum corrosion } \\
\text { protection. }\end{array}$ \\
\hline Process Vent Blower (B-320) & Design flow 90 acfm at $1 \mathrm{psi}$ vacuum & \\
\hline Relief Condenser (E-140) & $\begin{array}{l}\text { Design pressure: } 3 \mathrm{psig} / 1 \mathrm{psi} \text { vacuum at } \\
1,200^{\circ} \mathrm{C} \text { (tubes), } 50 \mathrm{psig} \text { at } 300^{\circ} \mathrm{F} \text { (shell) }\end{array}$ & $\begin{array}{l}\text { Duty to be determined based on sizing of } \\
\text { PSE 100-10. }\end{array}$ \\
\hline $\begin{array}{l}\text { Relief Demister }(T-142) \\
\text { Relief HEPA Filter ( } F-144)\end{array}$ & Design pressure: $\operatorname{atm} 300^{\circ} \mathrm{F}$ & Sizing to be determined \\
\hline
\end{tabular}


Table 2-3. General Design/Siting Criteria

\begin{tabular}{|c|c|c|}
\hline Parameter & Value/Units & Comments \\
\hline $\begin{array}{l}\text { Normal Atmospheric } \\
\text { Pressure }\end{array}$ & $\begin{array}{l}11.3 \mathrm{psia} \text {, based on elevation of } \\
7.500 \mathrm{ft} \text { (LANL location) }\end{array}$ & $\begin{array}{l}\text { Worst case for sizing thermal and } \\
\text { gas processing equipment. }\end{array}$ \\
\hline $\begin{array}{l}\text { Equipment Materials of } \\
\text { Construction }\end{array}$ & $\begin{array}{l}\text { Nickel alloys, chloride resistant } \\
\text { stainless steel, fiberglass-reinforced } \\
\text { plastic, and polymer-lined steel }\end{array}$ & $\begin{array}{l}\text { For corrosion control over } 20 \text {-year } \\
\text { design life, cost effectiveness, and } \\
\text { ease of decontamination. }\end{array}$ \\
\hline Structural Supports & Epoxy-coated carbon steel & $\begin{array}{l}\text { Ease of decontamination and ability } \\
\text { to withstand rigors of transportation, } \\
\text { commission, and decommission. }\end{array}$ \\
\hline Modular Construction & $\begin{array}{l}\text { Maximum of six modules can be } \\
\text { located in a radiological controlled area } \\
\text { (LANL) } \\
\text { Largest module shall not exceed } 11.5 \\
\mathrm{ft} \text { high, } 8 \mathrm{ft} \text { wide, and } 10 \mathrm{ft} \text { long for } \\
\text { shipment; can be up to } 18 \mathrm{ft} \text { high fully } \\
\text { assembled } \\
\text { Maximum weight of modules required } \\
\text { to be hoisted into position: } 4,000 \mathrm{lb} \\
\text { No limit on maximum weight of } \\
\text { modules not requiring hoisting }\end{array}$ & $\begin{array}{l}\text { For use at multiple sites - to be } \\
\text { transported on flat-bed trucks. } \\
\text { Maximum shipping dimensions } \\
\text { specified by DOT for highway } \\
\text { transportation. } \\
\text { Weight specified by LANL based on } \\
\text { capacity of overhead crane. }\end{array}$ \\
\hline Piping & $\begin{array}{l}\text { Stainless steel, nickel alloys, polymer- } \\
\text { lined steel (see P\&ID and piping } \\
\text { specifications) }\end{array}$ & $\begin{array}{l}\text { Designed and fabricated in } \\
\text { accordance with ASME B31.3. }\end{array}$ \\
\hline Electrical & $\begin{array}{l}\text { Designed for National Electrical Code } \\
\text { (NEC) Class 1, Division } 2 \text { areas } \\
\text { (except any utilities to be sited } \\
\text { outdoors) } \\
\text { Motors shall be totally enclosed, fan } \\
\text { cooled, have a } 1.15 \text { service factor or } \\
\text { specified for continuous service at } \\
7.500 \mathrm{ft} \text { elevation }\end{array}$ & $\begin{array}{l}\text { NEC Class } 1 \text {, Division } 2 \text { not required } \\
\text { for outdoor service. }\end{array}$ \\
\hline Secondary Containment & $\begin{array}{l}\text { Each skid shall be capable of complete } \\
\text { containment of } 110 \% \text { of the fluid } \\
\text { volume of the largest equipment item } \\
\text { on that skid }\end{array}$ & RCRA regulation. \\
\hline Instrumentation & $\begin{array}{l}\text { Designed for NEC Class 1, Division } 2 \\
\text { areas } \\
\text { All field instruments on the skid- } \\
\text { mounted equipment will be wired to a } \\
\text { local junction box; cabling will be used } \\
\text { from the junction boxes to the central } \\
\text { control panel for ease of system setup }\end{array}$ & $\begin{array}{l}\text { Programmable logic controllers } \\
\text { (PLC). } \\
\text { Capability for operation from a } \\
\text { central control panel with local } \\
\text { startstop switches for the equipment. }\end{array}$ \\
\hline General & $\begin{array}{l}40 \text { CFR } 264 \text { requirements will be } \\
\text { addressed in detailed design. }\end{array}$ & \\
\hline
\end{tabular}




\subsection{Process Parameters}

On the basis of the waste volumes described in Section 1.4 of this report, the PBR/SDP MTU will be designed around an organic feed rate of $15 \mathrm{gal} / \mathrm{d}$ and an aqueous solution feed rate of $75 \mathrm{gal} / \mathrm{d}$. The airflow rate will be $40 \mathrm{scfm}$ for both waste feed rates. The MTU design will be based on the material balances presented in Tables 1-1 through 1-3.

\subsection{Process/Mechanical Design Parameters}

\subsubsection{Equipment}

Table 2-4 lists the equipment required for the PBR/SDP MTU. The P\&IDs are presented in Appendix A.

Table 2-4. Equipment List

\begin{tabular}{||l|l|l||}
\hline \hline P\&ID No. & Tag No. & \multicolumn{1}{|c|}{ Description } \\
\hline E03456 & P-002 & Waste Transfer Pump \\
\hline E03456 & F-004 & Strainer \\
\hline E03456 & A-010 & Waste Feed Tank Agitator \\
\hline E03456 & T-010 & Waste Feed Tank \\
\hline E03457 & P-020 & Waste Feed Pump \\
\hline E03457 & P-022 & Waste Feed Pump \\
\hline E03457 & P-024 & Waste Feed Pump \\
\hline E03457 & R-100 & Packed-Bed Reactor \\
\hline E03457 & H-102 & Packed-Bed Reactor Heater \\
\hline E03457 & H-104 & Packed-Bed Reactor Heater \\
\hline E03457 & H-106 & Packed-Bed Reactor Heater \\
\hline E03457 & H-108 & Packed-Bed Reactor Heater \\
\hline E03457 & E-110 & Quench Chamber \\
\hline E03457 & E-112 & PBR Offgas Cooler \\
\hline E03488 & F-120 & PBR Offgas Filter \\
\hline E03488 & F-130A & SDP Inlet HEPA Filter \\
\hline E03488 & F-130B & SDP Inlet HEPA Filter \\
\hline E03489 & E-140 & Relief Condenser \\
\hline E03489 & T-142 & Relief Demister \\
\hline E03489 & F-144 & Relief HEPA Filter \\
\hline E03488 & R-201 & Silent-Discharge Plasma Cell Bank No. 1 \\
\hline E03488 & R-202 & Silent-Discharge Plasma Cell Bank No.2 \\
\hline
\end{tabular}


Table 2-4 (continued). Equipment List

\begin{tabular}{||l|l|l||}
\hline P\&ID No. & Tag No. & \multicolumn{1}{|c|}{ Description } \\
\hline E03488 & R-203 & Silent-Discharge Plasma Cell Bank No. 3 \\
\hline E03488 & $R-204$ & Silent-Discharge Plasma Cell Bank No. 4 \\
\hline E03458 & S-300 & Acid-Gas Scrubber \\
\hline E03458 & P-302 & Scrubber Pump \\
\hline E03458 & F-306 & Scrubber Filter \\
\hline E03459 & $P-304$ & Sodium Hydroxide Addition Pump \\
\hline E03458 & W-310 & Water Softener \\
\hline E03489 & B-320 & Process Vent Blower \\
\hline E03459 & CW-400 & Cooling Water Cooler \\
\hline E03459 & P-402 & Cooling Water Pump \\
\hline E03459 & P-410 & Sulfuric Acid Addition Pump \\
\hline E03459 & AC-420 & Air Compressor \\
\hline E03459 & P-430 & Antifoam Addition Pump \\
\hline E03459 & N-450 & Nitrogen Supply System \\
\hline
\end{tabular}

\section{Waste Transfer Pump (P-002)}

$\mathrm{P}-002$ is an air- or nitrogen-operated double-diaphragm pump with a discharge pulsation dampener.

$\mathrm{P}-002$ will have a capacity of at least $11 \mathrm{gal} / \mathrm{min}$, allowing it to empty a 55-gal drum of mixed waste in 5 minutes or less. P-002 has a suction lift of at least $10 \mathrm{ft}$ with an expected downstream pressure drop of $25 \mathrm{psi}$. The inlet dip tube will be inserted into the drum for pumping.

The temperature of the liquid waste feed is nominally $75^{\circ} \mathrm{F}$. Density will vary from 50 to 90 pounds per cubic foot $\left(\mathrm{lb} / \mathrm{ft}^{3}\right)$, and viscosity will typically range from about 0.5 to 10 centipoise (cP), although it may be much higher. The $\mathrm{pH}$ range is not known at this time, but may be expected to range from 1 to 14 . Coarse solids are expected to be minimal. Materials of construction for P-002 will be determined in the detailed design. Teflon is the most likely material.

\section{Strainer (F-004)}

F-004 is a Y-type strainer with a filter assembly equipped for ease of replacement during operation. The required mesh size is 7 mesh ( 0.111 in.) or finer, which will remove particles larger than $1 / 8$ in. in size that could plug the atomizing nozzles. F-004 can be periodically blown down as necessary to remove retained particulates. (Details of the washing and containerizing processes will be established in the detailed design.) The pressure drop across the filter will be limited to $5 \mathrm{psi}$ (clean) at the maximum flow of the Waste Transfer Pump ( $\mathrm{P}-002)$.

Materials of construction for $\mathrm{F}-004$ will be determined in the detailed design. Type 316 stainless steel is the most likely material to provide the corrosion resistance necessary to process chlorinated organics and wastes within a large $\mathrm{pH}$ range. 


\section{Waste Feed Tank (T-010)}

$\mathrm{T}-010$ is used for mixing the feed liquid, to keep solids from setting out, and to achieve a more uniform composition for the reactor feed. T-010 has a nominal capacity of 175 gal, sufficient to hold a 2-day supply of aqueous waste feed or a 10-day supply of organic waste feed. Total volume includes American Society of Mechanical Engineers (ASME) flanged and dished heads on the top and bottom of the tank. Mixing action is provided by the air-driven Waste Feed Tank Agitator (A-010).

Design temperature and pressure for $\mathrm{T}-010$ is $300^{\circ} \mathrm{F}$ and 50 pounds per square inch gauge (psig). $\mathrm{T}-010$ will be designed and constructed in accordance with the ASME Boiler and Pressure Vessel Code, Section VIII, "Rules for Construction of Pressure Vessels" (ASME 1992), and will be ASME code stamped.

Materials of construction for $\mathrm{T}-010$ will be determined during the detailed design. Teflon-lined carbon steel, Acetal (Delrin), PPS (Ryton), Kel-F, or 316L stainless steel have been identified as possible materials for corrosion protection. All welds will be, at a minimum, spot radiographed. For ease of radiological decontamination, the internal surfaces of $\mathrm{T}-010$ will have a Roughness Height Index Value 4 surface finish, as outlined in American National Standards Institute (ANSI) ANSI/ASME B46.1.

Level instrumentation on T-010 will not allow a drum of waste to be added to the tank unless the liquid level is at least 55 gal below the maximum operating volume. The $\mathrm{pH}$ of the tank contents will be measured by the $\mathrm{T}-010 \mathrm{pH}$ Meter ( $\mathrm{AE} 010-6$ ). When a $\mathrm{pH}$ less than 2 or greater than 12 is detected, an alarm will sound and the operator can manually adjust the $\mathrm{pH}$ by adding either sodium hydroxide or sulfuric acid, as required.

\section{Waste Feed Tank Agitator (A-010)}

A-010 is the agitator for the Waste Feed Tank. The agitator uses an air-driven motor to avoid a potential explosion hazard. The primary function of A-010 is to keep fine solids (which may contain high concentrations of radionuclides) in suspension, so it will be designed to "swipe" the bottom of T-010 to break up accumulations of solids. A secondary function of $\mathrm{A}-010$ is to provide mixing of the liquids to reduce variations in feed quality caused by nonhomogeneity of the liquids. Some of the waste streams will contain two or more immiscible layers that cannot be homogenized except by emulsification. Emulsification is not desired in $\mathrm{T}-010$ because emulsions can have unpredictable physical properties (for example, dramatic increases in viscosity), which could plug downstream piping and equipment and/or make accurate flow measurement difficult or impossible. Therefore, $\mathrm{A}-010$ will not be designed to emulsify.

Materials of construction for $\mathrm{A}-010$ will be determined at the detailed design phase. Teflon-lined carbon steel or $316 \mathrm{~L}$ stainless steel are the most likely materials. For ease of radiological decontamination, the impeller and shaft will have a Roughness Height Index Value 4 surface finish, as defined in ANSI/ASME B46.1.

\section{Waste Feed Pumps (P-020, P-022, P-024)}

$\mathrm{P}-020, \mathrm{P}-022$, and $\mathrm{P}-024$ will be variable-speed gear pumps, equipped with electric motors and installed in parallel to feed the PBR (R-100). Each pump will be designed to deliver up to $25 \mathrm{gal} / \mathrm{d}$ (65.7 cubic centimeters per minute $\left.\left[\mathrm{cm}^{3} / \mathrm{min}\right]\right)$ of aqueous waste or $5 \mathrm{gal} / \mathrm{d}\left(13.1 \mathrm{~cm}^{3} / \mathrm{min}\right)$ of organic waste at $25 \mathrm{psig}$. $\mathrm{R}-100$ is not designed to handle a pulsating flow, so it is important that the pumps deliver a steady flow at a steady pressure. 
The temperature of the waste feed is nominally $75^{\circ} \mathrm{F}$. Density will vary from 50 to $90 \mathrm{lb} / \mathrm{ft}^{3}$, viscosity will typically range from approximately 0.5 to $10 \mathrm{cP}$, and the $\mathrm{pH}$ range is 2 to 12 . Coarse solids will not exceed $1 / 8$ in. in size and are expected to be minimal. Materials of construction for the pumps will be determined during the detailed design.

\section{Packed-Bed Reactor (R-100)}

Normal operating conditions for $\mathrm{R}-100$ will be between $600^{\circ} \mathrm{C}$ and $1,050^{\circ} \mathrm{C}$, depending on the waste to be treated, and about 0.4 psi vacuum. R-100 consists of an 8-in.-diameter vertical section of pipe, containing a 4-foot-long section externally jacketed with electric heaters and packed with aluminum oxide balls and/or cylinders. The pipe is made of Haynes HR 160, a high-temperature alloy having great resistance to corrosion from chloride attack. The packing balls are 3/16 in. in diameter in the bottom foot of packing and $1 / 2$ in. in diameter for the rest of the heated length. Pilot PBR tests at LANL have demonstrated that using a section of smaller packing size at the bottom of the bed is more effective at retaining particulates in the bed than using a larger diameter packing throughout the entire bed length.

The waste feed is introduced through three nozzles located at the top of the bed. The incoming liquid feed is atomized with air to form a fine mist that is sprayed onto the top of the bed. The waste flows downward through the packing, where oxidation of organics takes place. The design will include a support grid for the packing, which will be constructed from the same materials as the reactor walls.

The electric PBR (Heaters $\mathrm{H}-102 . \mathrm{H}-104, \mathrm{H}-106$, and $\mathrm{H}-108$ ) are numbered top to bottom, with an independent temperature control for each heater. The heaters are sized to heat $75 \mathrm{gal} / \mathrm{d}$ of water and $40 \mathrm{scfm}$ of air from ambient temperature $\left(25^{\circ} \mathrm{C}\right)$ to $1,200^{\circ} \mathrm{C}$. The temperature measurements are made using a bundle of thermocouples inserted through the top of the bed inside a single tube, fabricated from Haynes 214 alloy or equivalent. The thermocouples will be arranged so that at least one thermocouple terminates approximately in the center of each zone. During normal operation with organic feeds, all four zones will be controlled at or near the same temperature. Aqueous feeds, which require more heat input from the external heaters, will exhibit a temperature profile that increases towards the bottom of the bed.

The outlet gases from R-100 pass though a short section of packed bed that is unheated and uninsulated, reducing the gas temperature from $1,050^{\circ} \mathrm{C}$ to about $500^{\circ} \mathrm{C}$ before being introduced into the Quench Chamber $(E-110)$. The length of uninsulated bed required to obtain the desired temperature drop may vary from one waste to another, or with different waste feed rates. Therefore, R-100 will be designed to be moved vertically up or down as much as 6 in. within the heaters.

Nearly all of the radionuclides are expected to concentrate in R-100 (see Section 1.2). Because removal of radiologically contaminated packing poses health and safety concerns, R-100 will be flanged to facilitate removal of the entire bed and reactor shell for disposal as radioactive waste. An alternate method, which should be included in the final PBR design, is to remove only the contaminated packing. This alternative will require removal of the bed support grid and dust controls to minimize fugitive dust emissions. The complete MTU package will include at least one spare packed pipe for replacement of a contaminated PBR.

$\mathrm{R}-100$ is designed to operate at $1,200^{\circ} \mathrm{C}$ and 10 psig or 1 psi vacuum. At a minimum, $\mathrm{R}-100$ will be designed and constructed in accordance with the ASME Boiler and Pressure Vessel Code, Section VIII, "Rules for Construction of Pressure Vessels" (ASME 1992). Welds made in the fabrication of R-100 will be 100 percent radiographed. 


\section{Quench Chamber (E-110)}

E-110 will ensure rapid cooling of offgas from oxidation of wastes containing chlorine, which could form $\mathrm{PCDD} / \mathrm{PCDF}$ if allowed to cool gradually. The temperature window for formation of PCDD/PCDF is between approximately 400 and $250{ }^{\circ} \mathrm{C}$. The offgas will be at approximately $500^{\circ} \mathrm{C}$ when it enters $\mathrm{E}-110$. The cooling medium for $\mathrm{E}-110$ is water, which is sprayed directly into the chamber in an ultrafine mist and allowed to vaporize on contact with the hot gas. The flow rate of the water is controlled by the E-110 Outlet Temperature Indicator/Controller (TIC 110-2) on the Quench Chamber outlet, which maintains the temperature at a normal setpoint of $250^{\circ} \mathrm{C}$.

E-110 consists of a section of 3-in. pipe fabricated from Haynes HR-160, a high-temperature alloy haying great resistance to corrosion from chloride. Design conditions for $\mathrm{E}-110$ are $600^{\circ} \mathrm{C}$ and $3 \mathrm{psig}$. Hot gas enters at the top of the chamber through a 2 -in. flange. The spray nozzle is mounted on a $1 / 4$-in. bulkhead tubing fitting. The maximum water-flow rate for $\mathrm{E}-110$ is $160 \mathrm{~cm}^{3} / \mathrm{min}$, based on cooling the offgas products from oxidation of $15 \mathrm{gal} / \mathrm{d}$ of Arachlor 1242 (design Case 2) from $50{ }^{\circ} \mathrm{C}$ to $200^{\circ} \mathrm{C}$. The quenched gas exits through a 2-in. side nozzle mounted $6 \mathrm{in}$. above the bottom of the chamber and goes to the PBR Offgas Cooler (E-112). The bottom section of E-110 has a small knockout section for removal of heavy particulates.

At a minimum, E-110 will be designed and constructed in accordance with ASME Boiler and Pressure Vessel Code, Section VIII, "Rules for Construction of Pressure Vessels" (ASME 1992). Expansion and contraction of E-110 will be addressed in the detailed design. Welds made while fabricating E-110 will be 100 percent radiographed.

\section{PBR Offgas Cooler (E-112)}

E-112 is a shell-and-tube heat exchanger designed to cool the offgas to $120^{\circ} \mathrm{C}$ before introducing it into the SDP. The inlet temperature will be either 250 or $500^{\circ} \mathrm{C}$, depending on whether or not the quench is used. The cooling medium for E-112 is cooled water from the Cooling Water Cooler (CW-400), at a nominal inlet temperature of $95^{\circ} \mathrm{F}$. The design duty for the cooler should be based on the worst of two scenarios:

- Normal operation. The design case is 40,017 British thermal units per hour (Btu/h), based on cooling the offgas from treatment of $75 \mathrm{gal} / \mathrm{d}$ of vaporized aqueous (100 percent water) waste and $40 \mathrm{scfm}$ of air from 500 to $120^{\circ} \mathrm{C}$.

- "Steaming out" the PBR to remove particulates. The design case is $12,960 \mathrm{Btu} / \mathrm{h}$, based on condensing 3.3 pounds per hour $(\mathrm{lb} / \mathrm{h})$ or $9.5 \mathrm{gal} / \mathrm{d}$ of water from $10 \mathrm{scfm}$ of air entering at $500{ }^{\circ} \mathrm{C}$ and condensing at an ambient pressure of 11.3 psia saturated, equivalent to $199^{\circ} \mathrm{F}$ or $93^{\circ} \mathrm{C}$.

The design conditions for $\mathrm{E}-112$ are 5 psig and full vacuum at $1,200^{\circ} \mathrm{F}\left(649^{\circ} \mathrm{C}\right)$. The material of construction will be Hastalloy C-22 or C-276.

\section{PBR Offgas Filter (F-120)}

F-120 removes residual particulates, such as fly ash and metallic flakes, from the PBR offgas stream. F-120 functions as a "coarse" filter to minimize plugging of the SDP Inlet HEPA Filters (F-130A and B) located immediately downstream. F-120 will be designed to remove 1-micron particles at an efficiency of 99 percent. Because the particulates may include radionuclides, the filter will be designed so that the entire bag can be removed and disposed as radioactive waste. Materials of construction for the bag filter 
housing will be stainless steel, and design conditions will be 3 psig and full vacuum at $300^{\circ} \mathrm{F}$. The filter element will be constructed from Gore-Tex or similar material.

\section{SDP Inlet HEPA Filters (F-130A and F-130B)}

F-130A and B remove radionuclides and other fine particulates from the PBR offgas stream so that they will not be carried into downstream process equipment. The two HEPA filters, each with a radiological decontamination factor (DF) of 3333 (removal of 99.97 percent of all particles 0.3 microns and larger) are installed in series, to give an overall DF of $1.1 \times 10^{7}$ (3333 squared). F-130A and B will be designed so that the entire filter element can be removed and disposed as radioactive or mixed waste. The HEPA filter element will be made from pleated fiberglass, and the filter housing will be stainless steel. Design conditions will be 3 psig and full vacuum at $300^{\circ} \mathrm{F}$.

\section{Relief Condenser (E-140)}

E-140 is a single-pass, horizontally mounted shell-and-tube condenser provided to condense vapors generated during an overpressure of the PBR $(\mathrm{R}-100)$ and relieved through the Relief Rupture Disk (PSE 100-10). The design duty for E-140 will be determined during the detailed design after PSE 100-10 has been sized. The vapors are on the tube side of the condenser. The cooling medium for E-140 is water from the Cooling Water Cooler $(\mathrm{CW}-400)$, at a nominal inlet temperature of $95^{\circ} \mathrm{F}$ and a temperature rise of $20^{\circ} \mathrm{F}$.

The design conditions for $\mathrm{E}-140$ are $5 \mathrm{psig}$ and full vacuum at $1,200^{\circ} \mathrm{F}\left(649^{\circ} \mathrm{C}\right)$ for the tube side, and $300^{\circ} \mathrm{F}$ and $50 \mathrm{psig}$ for the shell. Because $\mathrm{E}-140$ is intended for extremely infrequent operation, it will be considered sacrificial, in that the materials of construction will not be selected to withstand continuous operation at PBR offgas temperatures. (The need for a spare condenser will be evaluated during detailed design.) Materials of construction will be 316 stainless-steel for the tubes and heads, and carbon-steel for the shell. E-140 will be designed and constructed in accordance with ASME Boiler and Pressure Vessel Code, Section VIII, "Rules for Construction of Pressure Vessels" (ASME 1992), and ASME code stamped. Tube-side welds will be spot radiographed.

\section{Relief Demister ( $\mathrm{T}-142)$}

T-142 contains a mesh-type demister to coalesce the fine liquid droplets condensed in the Relief Condenser (E-140) into larger drops that can be collected and drained. T-142 will be sized for the maximum vapor flow rate through the Relief Rupture Disk (PSE 100-10), and will have a liquid holding capacity sufficient to contain the total calculated volume of the worst-case release. Liquid collected in T-142 will be drained after an overpressure incident is over. Both the tank and the demister will be fabricated from 316 stainless steel. The design conditions are 5 psig and full vacuum at $300^{\circ} \mathrm{F}$.

\section{Relief HEPA Filter (F-144)}

F-144 removes radionuclides and other particulates from the emergency relief line. F-144 will be designed so that the entire filter element can be removed and disposed as radioactive or mixed waste. The HEPA filter element will be made from pleated fiberglass, and the filter housing will be stainless steel. Design conditions will be 3 psig and full vacuum at $300^{\circ} \mathrm{F}$. 
Silent-Discharge Plasma (R-201, R-202, R-203, and R-204)

The SDP will be built in four sections or cell banks, each with a capacity of at least $10 \mathrm{scfm}$. Design and fabrication of the SDP will be handled by LANL and is outside the scope of this DDR.

\section{Acid-Gas Scrubber (S-300)}

The cooled gases enter the bottom of S-300 and flow upward through the packing material while a circulating sodium hydroxide solution flows counter-currently downward to neutralize the acid gases formed during the oxidation of halogenated compounds. The packing in the column provides vapor-liquid contact area for the neutralization reactions. The bottom section of S-300 serves as a liquid holding tank and provides liquid head for the Scrubber Pump ( $\mathrm{P}-302)$, which recirculates the sodium hydroxide solution to the top of S -300 .

The process design requirements for S-300 are based on Case 2 material balance (see Table 1-2), for 99.9 percent removal of hydrogen chloride from a gas stream having a total flow rate of $207.1 \mathrm{lb} / \mathrm{h}$ or 87.3 actual cubic feet per minute (acfm), and containing $3.07 \mathrm{lb} / \mathrm{h}$ of hydrogen chloride. The inside diameter of $\mathrm{S}-300$ is estimated at 8 in., and the flow rate of the circulating sodium hydroxide solution will be approximately $2 \mathrm{gal} / \mathrm{min}$. S-300 must be designed so that the pressure drop will not exceed $0.5 \mathrm{in}$. of water per foot of packing. The estimated packed height of S-300 is $6 \mathrm{ft}$. The design pressure for $\mathrm{S}-300$ is 3 psig at $300^{\circ} \mathrm{F}$.

Materials of construction for S-300 will be fiberglass-reinforced plastic (FRP), Teflon, or comparable temperature- and corrosion-resistant plastic. The materials should be suitable for extended service in a pH range of 2 to 12 . The design will allow for dismantling S-300 for internal inspection and radiological surveys.

As acid gases are converted to salt, the salt concentration in the recirculating liquid increases. As the salt concentration increases, the acid-gas scrubbing efficiency decreases and the potential for scaling increases, necessitating "blowdown" of the scrubber liquid. Increasing salt concentration will cause an increase in conductivity of the salt solution, as measured by the S-300 Conductivity Meter (AE 302-2) and the S-300 Conductivity Transmitter (AT 302-2). When the conductivity reaches the specified maximum, the S-300 Conductivity Indicator/ Controller (AIC 302-2) will cause the S-300 Blowdown Valve (EV 302-2) to open, and the blowdown liquid will be sent to a drum. (Ventilation will be provided so that steam from the drum does not pose a safety hazard.) The weight of the drum is continuously measured by the Scrubber Blowdown Drum Weight Cell (WE 302-6), and an alarm will sound on the control panel when the drum is approximately 90 percent full. This alarm also will trigger an interlock that closes EV 302-2. EV 302-2 will remain closed until the operator resets it by removing the full drum, replacing it with an empty one, and entering "Reset" on the control panel.

Blowdown of S-300 also will be required if the scrubber liquid level is high. In this case, EV 302-2 will open, allowing liquid to flow to the blowdown drum. (However, the interlock that closes EV 302-2 on high blowdown drum level will not allow EV 302-2 to open until the interlock is cleared by removal of the full drum and replacement with an empty drum.) More typically, the scrubber liquid level will slowly drop during normal operation due to vaporization of water by the hot inlet gases and the heat of reaction of the neutralization. A low liquid level will open the S-300 Process Water Supply Shutoff Valve (EV 300-4), bringing the scrubber liquid level back to setpoint.

The $\mathrm{pH}$ of the scrubber liquid is maintained at the desired value by adding 50 percent weight per weight $(\mathrm{w} / \mathrm{w})$ sodium hydroxide. The $\mathrm{pH}$ is measured by the $\mathrm{S}-300 \mathrm{pH}$ Meter (AE 300-6) and the S-300 $\mathrm{pH}$ 
Transmitter (AT 300-6), and sodium hydroxide solution is added by the Sodium Hydroxide Addition Pump (P-304).

\section{Scrubber Pump (P-302)}

$\mathrm{P}-302$ circulates the sodium hydroxide solution through the Acid-Gas Scrubber (S-300). P-302 is a centrifugal pump with a closed impeller, sized for a flow rate of $2 \mathrm{gal} / \mathrm{min}$ (the design liquid rate for $\mathrm{S}-300$ ) at $40 \mathrm{ft}$ total delivered head. The temperature of the circulating sodium hydroxide solution is $215^{\circ} \mathrm{F}$ (maximum), density is 56 to $65 \mathrm{lb} / \mathrm{ft}^{3}$, and viscosity is 0.6 to $1.1 \mathrm{cP}$. The $\mathrm{pH}$ range will normally be maintained between 6 and 8 . However, the pump must be designed for a $\mathrm{pH}$ range of 2 to 12 . Because the sodium hydroxide/salt solution is expected to be corrosive, all wetted parts of $\mathrm{P}-302$ will be Teflonlined. The pump will be equipped with an electric motor in accordance with Section 2.3 of this report.

\section{Sodium Hydroxide Addition Pump (P-304)}

$\mathrm{P}-304$ is a positive-displacement metering pump that supplies 50-percent sodium hydroxide solution to the Acid-Gas Scrubber (S-300). The sodium hydroxide solution (specific gravity of 1.525 ) is stored in a 55-gal drum. Sodium hydroxide solution is automatically provided to $\mathrm{S}-300$ on low $\mathrm{pH}$ as detected by the S-300 pH Indicator/Controller (AIC 300-6). The design flow rate of the pump is $41 \mathrm{~cm}^{3} / \mathrm{min}$ or $15.5 \mathrm{gal} / \mathrm{d}$ of sodium hydroxide solution. Material of construction for all wetted parts is 316 stainless steel.

Because a waste feed may occasionally be received with a $\mathrm{pH}$ of less than 2 , a sodium hydroxide line also is provided to the Waste Feed Tank ( $\mathrm{T}-010)$, which has continuous $\mathrm{pH}$ monitoring by the $\mathrm{T}-010 \mathrm{pH}$ Indicator (AI 010-6). Because sodium hydroxide addition to the Waste Feed Tank is not expected to be required frequently, there is no automatic control for the addition, which will be initiated and terminated manually by starting and stopping the pump.

\section{Scrubber Filter (F-306)}

F-306 is a basket-type filter installed in the circulating scrubber liquid line to remove metal hydroxides, salt precipitates, and other coarse and potentially plugging solids from the liquid. It is designed to remove 99 percent of all solids 10 microns and larger from a salt-water ( $\mathrm{pH} 4$ to 8 ) solution at a temperature of up to $215^{\circ} \mathrm{F}$.

\section{Water Softener (W-310)}

$\mathrm{W}-310$ is designed to remove dissolved salts and metals from process water (potable city water) before it is added to the Quench Chamber (E-110) and the Acid-Gas Scrubber (S-300) to minimize buildup of precipitates in those locations. The maximum combined water rate for the two services is $43.4 \mathrm{lb} / \mathrm{h}$ or $0.087 \mathrm{gal} / \mathrm{min}$.

\section{Process Vent Blower (B-320)}

$\mathrm{B}-320$ provides the motive force for the gas stream flowing through the PBR/SDP MTU, ensuring that the PBR and the SDP are always operated under a slight negative pressure. B-320 will be sized to deliver $50 \mathrm{scfm}$ at a temperature of $120^{\circ} \mathrm{C}$ and a draft of $0.5 \mathrm{psig}$. 


\section{Cooling Water Cooler (CW-400)}

$\mathrm{CW}-400$ is a closed-loop, nonevaporative fin-fan cooler that provides the cooling water for the PBR Offgas Cooler (E-112) and the Relief Condenser (E-140). E-140 is only used in emergency situations, during which the PBR feed will be shut off by interlocks. Therefore, the design duty for CW-400 is $40,017 \mathrm{Btu} / \mathrm{h}$, at a inlet temperature of $115^{\circ} \mathrm{F}$ and outlet temperature of $95^{\circ} \mathrm{F}$, based on the maximum duty of E-112.

\section{Sulfuric Acid Addition Pump (P-410)}

$\mathrm{P}-410$ is a positive-displacement metering pump that supplies concentrated ( 98 percent $w / w$ ) sulfuric acid to the Waste Feed Tank (T-010). The acid solution (specific gravity of 1.84) is stored in a 5-gal carboy. P-410 is identical to the Sodium Hydroxide Addition Pump (P-304), with a design flow rate of $41 \mathrm{~cm}^{3} / \mathrm{min}$ or $15.5 \mathrm{gal} / \mathrm{d}$. Material of construction for all wetted parts is 316 stainless steel. Sulfuric acid is supplied to the Waste Feed Tank ( $\mathrm{T}-010)$ when a $\mathrm{pH}$ greater than 12 is detected by the $\mathrm{T}-010 \mathrm{pH}$ Indicator (AI 010-6). Because sulfuric acid addition to the Waste Feed Tank is not expected to be required frequently, there is no automatic control for the acid addition, which will be initiated and terminated manually by starting and stopping the pump.

\section{Air Compressor (AC-420)}

AC-420 supplies oxidation air to the PBR (R-100), and compressed air to power the Waste Transfer Pump (P-002) and the Waste Feed Tank Agitator (A-010). The required capacity is 50 acfm at 60 psig minimum supply pressure. Because oil carryover from the air compressor is a potential source of contamination in $\mathrm{R}-100, \mathrm{AC}-420$ must be of a dry, oilless design, or must be provided with generalpurpose and coalescing filters, oil separators, and bleed ports to ensure that no oil can be entrained in the compressed air.

\section{Antifoam Addition Pump (P-430)}

$\mathrm{P}-430$ is a positive-displacement metering pump that supplies antifoam solution to the Waste Feed Tank $(\mathrm{T}-010)$. The antifoam solution is stored in a 5-gal carboy, and is automatically provided to $\mathrm{T}-010$ when a high foam level is detected by the T-010 Foam Sensor/Controller (AIC 010-11). The design flow rate of $\mathrm{P}-430$ is $50 \mathrm{~cm}^{3} / \mathrm{min}$. Material of construction for all wetted parts is 316 stainless steel.

\section{Nitrogen Supply System (N-450)}

$\mathrm{N}-450$ supplies nitrogen to maintain the pressure pad on the Waste Feed Tank ( $\mathrm{T}-010)$, and the nitrogen "sweep" on the pressure-relief header (see Figures A-2 and A-7 and Appendix C, HAZOP Action Item No. 103). The nitrogen will be stored in standard gas cylinders installed in parallel. The design flow requirement for the system is $2 \mathrm{scfm}$. The Nitrogen Supply Header Pressure Regulator (PCV 450-1) sets the pressure of the nitrogen supply header from $N-450$.

\subsubsection{Utility Requirements}

\section{Elẹctricity}

Each site will be expected to provide a single 480-volt, three-phase, 60-hertz electrical supply connection. The PBR/SDP MTU will be equipped with transformers for reducing voltage from this supply to the required voltage for each service on the skid. The preliminary single-line electrical diagram for the MTU, 
showing estimated electrical requirements and usage for each service, is presented in Figure A-8 of Appendix A. Electrical requirements are summarized in Table 2-5.

Table 2-5. Electrical Requirements for PBR/SDP MTU

\begin{tabular}{|c|c|c|}
\hline \multicolumn{3}{|c|}{480 VAC Motors } \\
\hline Tag No. & Description & hp \\
\hline$A C-420$ & Air Compressor & 25 \\
\hline$B-320$ & Process Vent Blower & 3 \\
\hline$C W-400$ & Cooling Water Cooler & 2 \\
\hline$P-302$ & Scrubber Pump & 1 \\
\hline $\mathrm{P}-402$ & Cooling Water Pump & 0.5 \\
\hline \multicolumn{3}{|c|}{120 VAC Motors } \\
\hline Tag No. & Description & hp \\
\hline$P-020$ & Waste Feed Pump No. 1 & 0.17 \\
\hline $\mathrm{P}-022$ & Waste Feed Pump No. 2 & 0.17 \\
\hline $\mathrm{P}-024$ & Waste Feed Pump No. 3 & 0.17 \\
\hline$P-304$ & Sodium Hydroxide Addition Pump & 0.17 \\
\hline$P-410$ & Sulfuric Acid Addition Pump & 0.17 \\
\hline$P-430$ & Antifoam Addition Pump & 0.17 \\
\hline \multicolumn{3}{|c|}{ 240/480 VAC Heaters } \\
\hline Tag No. & Description & kW \\
\hline $\mathrm{H}-102$ & Packed-Bed Reactor Heater No. 1 & 20 \\
\hline $\mathrm{H}-104$ & Packed-Bed Reactor Heater No. 2 & 20 \\
\hline $\mathrm{H}-106$ & Packed-Bed Reactor Heater No. 3 & 20 \\
\hline $\mathrm{H}-108$ & Packed-Bed Reactor Heater No. 4 & 20 \\
\hline$R-201$ & Silent-Discharge Plasma Cell Bank No. 1 & 20 \\
\hline$R-202$ & Silent-Discharge Plasma Cell Bank No. 2 & 20 \\
\hline $\mathrm{R}-203$ & Silent-Discharge Plasma Cell Bank No. 3 & 20 \\
\hline R-204 & Silent-Discharge Plasma Cell Bank No. 4 & 20 \\
\hline
\end{tabular}

Key:

hp $=$ horsepower

$\mathrm{kW}=$ kilowatts

VAC $=$ voltage, altemating current

Air

An Air Compressor (AC-420) will be installed as part of the PBR/SDP MTU. The estimated maximum air requirements for the PBR/SDP MTU are listed in Table 2-6. The air requirements for $\mathrm{P}-002$ and $A-010$ will be confirmed during the detailed design.

Table 2-6. Estimated Air Requirements for PBR/SDP MTU

\begin{tabular}{||l|c|}
\hline \multicolumn{1}{|c|}{ Service } & Air Flow (scfm) \\
\hline Packed-Bed Reactor $(\mathrm{R}-100)$ & 40 \\
\hline Waste Transfer Pump (P-002) & 5 \\
\hline Waste Feed Tank Agitator (A-010) & 8 \\
\hline
\end{tabular}




\section{Process Water}

Process water is used as the makeup water to the Quench Chamber $(E-110)$ and to the Acid-Gas Scrubber (S-300). Maximum flows for these two services are $20.9 \mathrm{lb} / \mathrm{h}(60.0 \mathrm{gal} / \mathrm{d})$ and $22.5 \mathrm{lb} / \mathrm{h}(65 \mathrm{gal} / \mathrm{d})$, respectively. Because both of these maximums occur during treatment of high-chloride waste, the maximum instantaneous consumption of process water is $43.4 \mathrm{lb} / \mathrm{h}$. Process water will be supplied by the sites. A Water Softener (W-310) will be supplied on the process water supply to both E-110 and S-300 to minimize scaling from salts and other dissolved solids.

\section{Cooling Water}

Cooling water is required on a continuous basis by the PBR Offgas Cooler (E-112). The maximum cooling water flow rate is $2,005 \mathrm{lb} / \mathrm{h}$ ( $4 \mathrm{gal} / \mathrm{min}$ ), based on a duty of $40,071 \mathrm{Btu} / \mathrm{h}$ and a temperature rise of $20^{\circ} \mathrm{F}$. Cooling water also is continuously circulated through the Relief Condenser (E-140), but it will have no duty except when a release occurs from the Waste Feed Tank $(T-010)$ or the PBR $(R-100)$, which is not anticipated in the lifetime of the MTU. Cooling water for E-112 and E-140 is supplied by the Cooling Water Pump (P-402) from the Cooling Water Cooler (CW-400), a closed-loop, air-cooled water cooler with a required duty of $40,017 \mathrm{Btu} / \mathrm{h}$ designed to supply cooling water at a nominal temperature of $95^{\circ} \mathrm{F}$.

\section{Nitrogen}

Nitrogen is used to maintain the pressure pad on the Waste Feed Tank (T-010), and the nitrogen "sweep" on the pressure-relief header. The nitrogen will be supplied from the Nitrogen Supply System $(\mathrm{N}-450)$, which consists of standard gas cylinders installed in parallel. The design flow requirement for the system is $2 \mathrm{scfm}$.

\section{Chemicals}

The chemicals required for the PBR/SDP MTU are sodium hydroxide, sulfuric acid, and antifoam. Sodium hydroxide will be supplied as a 50-percent solution in 55-gal drums. Sulfuric acid, which will be required in much smaller amounts, will be supplied as a 98-percent solution in 5-gal carboys. Antifoam will also be supplied in 5-gal carboys. Chemicals will be ordered after the MTU arrives at each site, and unused chemicals will remain the property of the site at the conclusion of treatment.

The maximum consumption rate of sodium hydroxide is $3.36 \mathrm{lb} / \mathrm{h}$ of pure $\mathrm{NaOH}$, or $6.72 \mathrm{lb} / \mathrm{h}$ of 50 -percent sodium hydroxide solution. The sodium hydroxide solution will only be required for treatment of halogenated wastes (plus an unknown, but probably very small, amount for any $\mathrm{pH}$ adjustment of the feed). Of the seven waste streams currently slated for treatment with PBR/SDP, the following three contain halogenated compounds.

- LA-W 907: Halogenated organic liquids. Total current inventory and estimated 5-year generation is $16.58 \mathrm{~m}^{3}(4,381 \mathrm{gal})$.

- PTX-TG 1.2: Halogenated organic liquids. Total current inventory and estimated 5-year generation is $2.06 \mathrm{~m}^{3}$ (544 gal).

- SNL/NM-TG 11: Uncategorized organic liquids. Total current inventory and estimated 5-year generation is $2.7 \mathrm{~m}^{3}$ (713 gal). Only the grinding sludge portion of this waste is expected to contain halogens. 
The halogen concentration in these wastes is not known at this time, so it is not possible to estimate the total sodium hydroxide required. At the maximum rate of consumption, based on treatment of a waste containing 42 percent chloride, a 55-gal drum of sodium hydroxide would last 103 hours of continuous operation. Sodium hydroxide is readily available in most locations, so it would not be necessary to keep more than about two drums of sodium hydroxide on hand at any time.

Sulfuric acid consumption is unknown, but expected to be minimal. The acid will only be used for $\mathrm{pH}$ adjustment of the feed and the $\mathrm{pH}$ adjustment requirements cannot be calculated at this time because the current $\mathrm{pH}$ and buffering properties of the waste streams have not yet been determined. Antifoam usage also is unknown and cannot be determined because the foaming properties of the waste streams have not yet been determined.

\subsubsection{Piping/Vessel Specifications}

All pressure vessels, associated piping, and piping systems will be designed and fabricated in accordance with ANSIASME B31.3, "Chemical Plant and Petroleum Refinery Piping," and ASME Boiler and Pressure Vessel Code, Section VIII, "Rules for Construction of Pressure Vessels" (ASME 1992).

Materials of construction for the major sections of piping of the PBR/SDP MTU are listed as the Pipe Specification on Figure A-1. The pipe specification is the second element in the line numbers shown on the P\&IDs (Figures A-2 through A-7). The detailed Pipe Specifications will be developed during the detailed design. Table 2-7 lists the materials of construction corresponding to each pipe specification.

Table 2-7. Piping Materials and Design Requirements for PBR/SDP MTU

\begin{tabular}{||c|l|l|c||}
\hline $\begin{array}{c}\text { Specification } \\
\text { Number }\end{array}$ & \multicolumn{1}{|c|}{ Size } & \multicolumn{1}{|c|}{ Material of Construction } & $\begin{array}{c}\text { Design } \\
\text { Pressure/Temperature } \\
\left(\mathrm{psi} /{ }^{\circ} \mathrm{F} \text { ) }\right.\end{array}$ \\
\hline \hline $2.6 \mathrm{~A}$ & $1 \mathrm{in}$. and larger & High alloy, Haynes HR-160 or equal & $15 / 2,200$ \\
\hline $2.6 \mathrm{~B}$ & 1 in. and larger & $316 \mathrm{~L}$ Stainless Steel Pipe & $50 / 600$ \\
\hline $2.6 \mathrm{C}$ & $3 / 4$ in. and smaller & 304 Stainless Steel Tubing & $150 / 300$ \\
\hline $2.6 \mathrm{D}$ & $3 / 4$ in. and smaller & Type L Copper Tubing & $75 / 70$ \\
\hline
\end{tabular}

Table 2-8 lists all the lines shown on the P\&IDs (Figures A-2 through A-7). This line list can be used to cross-reference the stream sheets in Appendix D.

Table 2-8. PBR/SDP MTU Pipe Line List

\begin{tabular}{|c|c|c|l|l||}
\hline Size & $\begin{array}{c}\text { Line } \\
\text { Specification }\end{array}$ & Number & \multicolumn{1}{|c|}{ Service } & \multicolumn{1}{|c||}{ P\&ID } \\
\hline 1 & $2.6 \mathrm{~B}$ & $002-01$ & Waste from P-002 to F-004 & E03456 \\
\hline 1 & $2.6 \mathrm{~B}$ & $002-02$ & Waste from F-004 to $T-010$ & E03456 \\
\hline 1 & $2.6 \mathrm{~B}$ & $002-03$ & Waste to Solids Blowdown & E03456 \\
\hline 0.5 & $2.6 \mathrm{C}$ & $010-01$ & Waste from T-010 to P-020/2/4 & E03456 \\
\hline 0.5 & $2.6 \mathrm{C}$ & $010-02$ & T-010 vent to PBR & E03456, E03457 \\
\hline
\end{tabular}


Table 2-8 (continued). PBR/SDP MTU Pipe Line List

\begin{tabular}{|c|c|c|c|c|}
\hline Size & $\begin{array}{c}\text { Line } \\
\text { Specification }\end{array}$ & Number & Service & P\&ID \\
\hline 0.5 & $2.6 \mathrm{C}$ & $010-03$ & Waste to $\mathrm{P}-020$ & E03457 \\
\hline 0.5 & $2.6 \mathrm{C}$ & $010-04$ & Waste to $\mathrm{P}-022$ & E03457 \\
\hline 0.5 & $2.6 \mathrm{C}$ & $010-05$ & Waste to $P-024$ & E03457 \\
\hline 2 & $2.6 \mathrm{~B}$ & $010-06$ & T-010 Pressure Relief to E-140 & E03456, E03489 \\
\hline 0.5 & $2.6 \mathrm{C}$ & $020-01$ & Waste from $P-020$ to $R-100$ & E03457 \\
\hline 0.5 & $2.6 \mathrm{C}$ & $022-01$ & Waste from $P-022$ to $R-100$ & E03457 \\
\hline 0.5 & $2.6 \mathrm{C}$ & 024-01 & Waste from $P-024$ to $R-100$ & E03457 \\
\hline 0.75 & $2.6 \mathrm{D}$ & $100-01$ & Air to PBR & E03457 \\
\hline 0.5 & 2.6D & $100-02$ & Air to PBR Nozzle \#1 & E03457 \\
\hline 0.5 & $2.6 D$ & $100-03$ & Air to PBR Nozzle \#2 & E03457 \\
\hline 0.5 & $2.6 \mathrm{D}$ & $100-04$ & Air to PBR Nozzle \#3 & E03457 \\
\hline 1 & $2.6 \mathrm{~A}$ & $100-05$ & PBR Relief to E-140 & E03457, E03489 \\
\hline 0.25 & $2.6 D$ & $110-01$ & Quench Water to E-110 & E03457, E03458 \\
\hline 3 & $2.6 \mathrm{~A}$ & $110-02$ & $E-110$ to $E-112$ & E03457 \\
\hline 0.75 & 2.6D & $112-01$ & CWS to E-112 & E03457, E03489 \\
\hline 0.75 & $2.6 \mathrm{D}$ & $112-02$ & CWR from E-112 & E03457, E03459 \\
\hline 2 & $2.6 \mathrm{~B}$ & $112-03$ & $E-112$ to SDP & $E 03457, E 03488$ \\
\hline 2 & $2.6 \mathrm{~B}$ & $120-01$ & F-120 Bypass & E03488 \\
\hline 2 & $2.6 \mathrm{~B}$ & $120-02$ & F-120/130A/B Bypass & E03488 \\
\hline 2 & $2.6 \mathrm{~B}$ & $120-03$ & SDP Discharge Return to F-120 & E03488 \\
\hline 2 & $2.6 \mathrm{~B}$ & $130-01$ & F-130A Bypass & E03488 \\
\hline 2 & $2.6 \mathrm{~B}$ & $130-02$ & F-130A Outlet & E03488 \\
\hline 2 & $2.6 \mathrm{~B}$ & $130-03$ & F-130B Bypass & E03488 \\
\hline 2 & $2.6 \mathrm{~B}$ & $130-04$ & F-130B Outlet & E03488 \\
\hline 1 & $2.6 \mathrm{~B}$ & $140-01$ & $E-140$ to $T-142$ & E03489 \\
\hline 1 & $2.6 \mathrm{~B}$ & $142-01$ & $T-142$ to $F-144$ & E03489 \\
\hline 1 & $2.6 \mathrm{~B}$ & $144-01$ & F-144 to Vent & E03489 \\
\hline 1 & $2.6 \mathrm{~B}$ & $201-01$ & R-201 Inlet & E03488 \\
\hline 1 & $2.6 \mathrm{~B}$ & 201-02 & R-201 Outlet & E03488 \\
\hline 2 & $2.6 \mathrm{~B}$ & $201-03$ & SDP Outlet to S-300 & E03488, E03458 \\
\hline 1 & $2.6 \mathrm{~B}$ & 202-01 & R-202 Inlet & E03488 \\
\hline 1 & $2.6 \mathrm{~B}$ & $202-02$ & R-202 Outlet & E03488 \\
\hline 1 & $2.6 \mathrm{~B}$ & 203-01 & R-203 Inlet & E03488 \\
\hline 1 & $2.6 \mathrm{~B}$ & $203-02$ & R-203 Outlet & E03488 \\
\hline 1 & $2.6 \mathrm{~B}$ & 204-01 & R-204 Inlet & E03488 \\
\hline 1 & $2.6 \mathrm{~B}$ & 204-02 & R-204 Outlet & E03488 \\
\hline 1.5 & $2.6 \mathrm{~B}$ & $300-01$ & S-300 Bypass & E03458 \\
\hline 2 & $2.6 \mathrm{~B}$ & $300-02$ & S-300 Outlet & $E 03458, E 03489$ \\
\hline 0.25 & $2.6 \mathrm{D}$ & $300-03$ & Process Water to $S-300$ & E03458 \\
\hline 0.5 & $2.6 \mathrm{C}$ & $300-04$ & S-300 to P-302 Circulating Liquid & E03458 \\
\hline 0.5 & $2.6 \mathrm{C}$ & $302-01$ & P-302 to S -300 Circulating Liquid & E03458 \\
\hline
\end{tabular}


Table 2-8 (continued). PBR/SDP MTU Line List

\begin{tabular}{||c|c|c|l|l||}
\hline Size & $\begin{array}{c}\text { Line } \\
\text { Specification }\end{array}$ & Number & \multicolumn{1}{|c|}{ Service } & \multicolumn{1}{|c|}{ P\&ID } \\
\hline 0.5 & $2.6 \mathrm{C}$ & $302-02$ & S-300 Blowdown & E03458 \\
\hline 0.25 & $2.6 \mathrm{C}$ & $304-01$ & Caustic Header & E03459 \\
\hline 0.25 & $2.6 \mathrm{C}$ & $304-02$ & Caustic to S-300 & E03458, E03459 \\
\hline 0.25 & $2.6 \mathrm{C}$ & $304-03$ & Caustic to T-010 & E03456, E03459 \\
\hline 2 & $2.6 \mathrm{~B}$ & $320-01$ & B-320 to Vent & E03489 \\
\hline 0.75 & $2.6 \mathrm{D}$ & $400-01$ & CW-400 to P-402 & E03459 \\
\hline 0.75 & $2.6 \mathrm{D}$ & $402-01$ & CWS to E-140 & E03459, E03489 \\
\hline 0.25 & $2.6 \mathrm{C}$ & $410-01$ & Sulfuric Acid to T-010 & E03456, E03459 \\
\hline 0.75 & $2.6 \mathrm{D}$ & $420-01$ & Main Air Header & E03459 \\
\hline 0.5 & $2.6 \mathrm{D}$ & $420-02$ & Air to A-010 & E03456, E03459 \\
\hline 0.375 & $2.6 \mathrm{D}$ & $420-03$ & Air to P-002 & E03456, E03459 \\
\hline 0.75 & $2.6 \mathrm{D}$ & $420-04$ & Air from AC-420 to PBR & E03457, E03459 \\
\hline 0.25 & $2.6 \mathrm{C}$ & $430-01$ & Antifoam to T-010 & E03456, E03459 \\
\hline 0.5 & $2.6 \mathrm{D}$ & $450-01$ & Nitrogen Supply to T-010 & E03456, E03459 \\
\hline 0.5 & $2.6 \mathrm{D}$ & $450-02$ & Nitrogen Sweep to Relief Header & E03456, E03459 \\
\hline \hline
\end{tabular}

\section{Corrosion Allowance .}

The general corrosion allowance will be $1 / 8$ in. for a 20 -year design life. Averaging $1 / 8$ in. over 20 years allows $0.00625 \mathrm{in}$. of corrosion per year (6.25 mil/year or $158.8 \mathrm{micrometers} / \mathrm{year}$ ).

Corrosion rates for high-temperature nickel-alloy materials of construction in extremely high temperature, high-chloride services are not well defined. Corrosion allowances for equipment in these services (e.g., R-100 and E-110) will be set during the detailed design, in consultation with the alloy manufacturer.

\section{Welds}

At a minimum, all pressure vessel welds will be spot radiographed. Specific equipment welds are detailed in Section 2.2.1. All radiological service piping welds and welded fittings will be 100 percent radiographed.

\section{Fittings}

All nickel-alloy piping will be lap-joint flanged to eliminate expensive fittings and welding.

\section{Skid Breaks}

Where piping extends across skid or shipping break boundaries, flange pairs shall be provided at the skid interface so that the piping can be disconnected and blinded on both skids for transportation. 


\subsubsection{Process Control}

The control logic for the PBR/SDP MTU is shown on the P\&IDs (Appendix A). Principal control loops include the following.

- Waste feed rate to the PBR (R-100) will be operator specified using the Total Waste Feed Flow Indicator/ Controller (FIC 010-8). The flow setpoint of FIC 010-8 will be divided by the total number of operating Feed Pumps (P-020, P-022, and P-024), as indicated by the position of the pump run/stop switches. The result is used as the setpoint for the Feed Pump flow controllers (FIC 020/022/024-2), which adjust the rates of the Feed Pumps so that the overall feed rate is maintained and divided equally among the operating feed nozzles.

- Air rate to R-100 will be operator specified using the R-100 Total Air Flow Indicator/Controller (FIC 100-11). The flow setpoint of FIC 100-11 will be divided by the total number of operating feed nozzles, as indicated by the position of the R-100 Nozzle Air Flow Solenoid Valves (EV 100-5, EV 100-6, and EV 100-7). The result is used as the setpoint for the R-100 Nozzle Air Flow Indicator/ Controllers (FIC 100-5, FIC 100-6, and FIC 100-7), which adjust the position of the air flow control valves so that the overall air rate is maintained and divided equally among the operating feed nozzles.

- Temperatures of the zones in R-100 are individually controlled using four heater Temperature Indicator/Controllers (TIC 100-1, TIC 100-2, TIC 100-3, and TIC 100-4). Setpoints for the controllers are set by the operator.

- The maximum temperature in the bed is determined by taking the maximum reading from the four R-100 Temperature Indicator/Controllers (TIC 100-1, TIC 100-2, TIC 100-3, and TIC 100-4) and the three R-100 Midzone Temperature Indicators (TI 100-16, TI 100-17, and TI 100-18). The result of this calculation is stored as the R-100 Maximum Temperature Indicator/Controller (TIC 100-19). If the reading on TIC 100-19 exceeds the high alarm point (normally $1100^{\circ} \mathrm{C}$ ), the setpoint to the R-100 Total Air Flow Indicator/Controller (FIC 100-11) will be automatically increased.

- Pressure at R-100 inlet (top) is controlled by the R-100 Inlet Pressure Indicator/Controller (PIC 100-8), which will adjust and balance the flow through the SDP cells as needed to maintain the setpoint (see below).

- Water flow to the Quench Chamber (E-110), when needed, will be controlled by the Quench Water Flow Indicator/Controller (FIC 110-1) to maintain the quench outlet temperature setpoint of the E-110 Outlet Temperature Indicator/Controller (TIC 110-2), which will be operator specified.

- Cooling water flow to the PBR Offgas Cooler (E-112) will be controlled by the E-112 Cooling Water Flow Indicator/Controller (FIC 112-1) to maintain the SDP inlet temperature setpoint (normally $120^{\circ} \mathrm{C}$ or $248^{\circ} \mathrm{F}$ ) of the E-112 Outlet Temperature Indicator/Controller (TIC 112-2).

- Feed rates to the SDP cell banks are controlled by the four Inlet Flow Indicators/Controllers (FIC 201-1, FIC 202-1, FIC 203-1, and FIC 204-1). The flow rate to the four banks is totaled and then divided by the number of banks operating to obtain the required setpoint for all four controllers. An additional input comes from the R-100 Inlet Pressure Indicator Controller (PIC 100-8), which will cause the SDP Flow Control Valves (FCV 201-1, FCV 202-1, FCV 203-1, and FCV 204-1) to adjust as needed to compensate for changes in the total feed to $R-100$. This control loop is disabled when the SDP is not in service. (It may be possible to replace this control system with symmetrical piping without compromising uniform flow distribution. This will be investigated during detailed design.) 
- The $\mathrm{pH}$ of the circulating solution in the Acid-Gas Scrubber $(\mathrm{S}-300)$ is controlled by the $\mathrm{S}-300 \mathrm{pH}$ Indicator/Controller (AIC 300-6), which will activate the Sodium Hydroxide Addition Pump (P-304) as needed to add sodium hydroxide solution and maintain the specified scrubber $\mathrm{pH}$.

- The salt concentration in S-300 is controlled by the S-300 Conductivity Indicator/Controller (AIC 302-2), which will open the S-300 Blowdown Valve (EV 302-2) as needed to maintain the specified scrubber solution conductivity.

- $\mathrm{S}-300$ is designed to constantly evaporate a small amount of water. The scrubber liquid level is maintained by the S-300 Level Indicator (LI 300-4), which will open the S -300 Process Water Supply Shutoff Valve (EV 300-4) when a low scrubber liquid level is detected, letting in process water to maintain the scrubber level. If S-300 gains rather than loses liquid level (due to system heat losses being much greater than anticipated), LI 300-4 will open EV 302-2 to bring the level back to the setpoint.

- The overall pressure drop across the PBR/SDP MTU is controlled by the MTU Pressure Differential Indicator/Controller (PDIC 100-14), which adjusts the B-320 Inlet Vanes Positioner (ZC 320-2) on the Process Vent Blower (B-320) as needed to maintain the specified setpoint.

- Control of $\mathrm{pH}$ in the Waste Feed Tank $(\mathrm{T}-010)$ is manual. The $\mathrm{pH}$ is monitored by the $\mathrm{T}-010 \mathrm{pH}$ Indicator (AI 010-6), which will alarm when the $\mathrm{pH}$ drops below 3 , signaling a need to add sodium hydroxide solution, or above 11 , signaling a need to add sulfuric acid.

- Antifoam is added to $\mathrm{T}-010$ automatically when a high foam level is detected by the $\mathrm{T}-010$ Foam Sensor/Controller (AIC 010-11), which will start the Antifoam Addition Pump (P-430). and add antifoam as needed.

- The pressure in T-010 is controlled by the T-010 Pressure Indicator/Controller (PIC 010-2). When liquid waste is added to T-010, PIC 010-2 will open the T-010 Pressure Control Valve (PCV 010-2A), venting the displaced vapors to R-100. During normal operation, the liquid level in $\mathrm{T}-010$ will slowly drop as liquid waste is withdrawn. To maintain the pressure in T-010, PIC 010-2 will open the low pressure T-010 Pressure Control Valve (PCV 010-2B) as needed to allow nitrogen to flow into $\mathrm{T}-010$. When $\mathrm{R}-100$ is out of service (as indicated by a closed $\mathrm{R}-100$ Air Shutoff Valve [EV 100-11]), or either too cold to adequately treat vapors or too hot for vapors to be added safely (as indicated by the R-100 Maximum Temperature Indicator/Controller [TI 100-19]), an interlock will close the T-010 Vent Shutoff Valve (EV 010-9) so that waste tank vapors will not be vented to R-100. To prevent overpressurizing the waste feed tank by addition of waste when the vent line is closed, another interlock will close the air supply line to the Waste Transfer Pump (P-002) on high pressure in the waste tank as indicated by the T-010 Pressure Indicator (PIC 010-2).

\section{Process Control Hardware}

Logic control will be handled by an Allen-Bradley programmable logic controller (PLC) with digital data interface. All transducers will either have digital input and output $(\mathrm{I} / \mathrm{O})$ capability, or will be converted to digital I/O.

\section{Interlocks .}

The process control system described above may be thought of as "analog" in the sense that the values of the operating parameters that are monitored by the various control loops vary continuously, and the system 
continuously adjusts the controlled parameters to keep the actual values at the desired setpoints. The design of the PBR/SDP MTU control system includes a number of "discrete" points, such as low-flow switches, which generate a digital on/off signal when a discrete setting is reached. Also, the analog measurements can generate discrete alarm signals when the actual value of a measurement deviates unacceptably from the desired value, such as when the actual value is very high, or high-high (HH), compared to its intended value, or when it is very low, or low-low (LL).

Many of these discrete points activate interlocks that take additional discrete actions such as opening or closing valves, or stopping pumps, when a deviation from normal operating conditions would make continuing that operation unsafe or otherwise undesirable. Interlocks also may serve as "permissives" by not permitting operations to be done at inappropriate times. Some interlocks may serve both purposes. An example is Interlock 4, which does not allow EV 010-10, the T-010 vent valve, to open and vent the organic/nitrogen mixture in the head space of $\mathrm{T}-010$ into $\mathrm{R}-100$ if any of three conditions exist:

- The main air flow valve to R-100 (EV 100-11) is closed.

- The temperature in R-100 (TI 100-19) is too low (LL) for efficient oxidation.

- TI 100-19 is too high (HH) to safely allow additional organics to be added.

Under the first condition in this example, Interlock 4 functions as a permissive and under the third condition it is a safety shutdown. Under the second condition, Interlock 4 functions primarily as a permissive because the most likely reason for TI $100-19$ to be too low is that R-100 is out of service. However, if the temperature in $\mathrm{R}-100$ should drop below the LL setpoint during operation, the interlock also will serve as a safety shutdown of the $\mathrm{T}-010$ vent line.

Interlocks are indicated on the P\&IDs (Appendix A) using diamond symbols. A summary of the interlocks is provided in Table $2-9$.

The interlock classification is assigned according to the ranking criteria and guidelines listed in Table 2-10. Note that because the hazard potential of the PBR/SDP process is very low, no interlock classification higher than 4 has been assigned for the PBR/SDP MTU.

Table 2-9. Interlock Description

\begin{tabular}{|c|c|c|c|c|c|}
\hline No. & Initiation & Condition & Output & Action & $\begin{array}{c}\text { Interlock } \\
\text { Class }\end{array}$ \\
\hline 1 & $\mathrm{Pl} \mathrm{010-2}$ & $\mathrm{HH}$ & HS 002-3 & Close EV 002-3 & 4 \\
\hline \multirow[t]{2}{*}{2} & L1 010-4 & $\mathrm{HH}$ & \multirow[t]{2}{*}{ HS 002-3 } & \multirow[t]{2}{*}{ Close EV 002-3 } & \multirow[t]{2}{*}{4} \\
\hline & 니 010-7 & $\mathrm{HH}$ & & & \\
\hline \multirow[t]{2}{*}{3} & LI 010-4 & LL & \multirow[t]{2}{*}{ HS 010-1 } & \multirow[t]{2}{*}{ Close EV 010-1 } & \multirow[t]{2}{*}{4} \\
\hline & 니 010-7 & LL & & & \\
\hline \multirow[t]{3}{*}{4} & EV 100-11 & Closed & \multirow[t]{3}{*}{ EV 010-10 } & \multirow[t]{3}{*}{ Close } & \multirow[t]{3}{*}{4} \\
\hline & TI 100-19 & $\mathrm{HH}$ & & & \\
\hline & TI 100-19 & LL & & & \\
\hline
\end{tabular}


Table 2-9 (continued). Interlock Description

\begin{tabular}{|c|c|c|c|c|c|}
\hline No. & Initiation & Condition & Output & Action & $\begin{array}{c}\text { Interlock } \\
\text { Class } \\
\end{array}$ \\
\hline \multirow[t]{5}{*}{5} & \multirow[t]{5}{*}{ FI 100-11 } & \multirow[t]{5}{*}{ LL } & HS 020-2 & Close & \multirow[t]{5}{*}{4} \\
\hline & & & IC 100-1 & Power Off & \\
\hline & & & IC 100-2 & Power Off & \\
\hline & & & IC 100-3 & Power Off & \\
\hline & & & IC 100-4 & Power Off & \\
\hline \multirow[t]{8}{*}{6} & PI 100-8 & $\mathrm{HH}$ & HS 020-2 & Close & \multirow[t]{8}{*}{4} \\
\hline & TI 100-12 & $\mathrm{HH}$ & EV 010-10 & Close & \\
\hline & TIC 110-2 & $\mathrm{HH}$ & IC 100-1 & Power Off & \\
\hline & PDI 100-13 & $\mathrm{HH}$ & IC 100-2 & Power Off & \\
\hline & PSH 010-10 & Fail & IC 100-3 & Power Off & \\
\hline & TIC 112-2 & $\mathrm{HH}$ & \multirow[t]{3}{*}{ IC $100-4$} & \multirow[t]{3}{*}{ Power Off } & \\
\hline & FSL 140-1 & $\mathrm{LL}$ & & & \\
\hline & Operator Initiatic & & & & \\
\hline \multirow[t]{3}{*}{7} & Operator Initiatio & & \multirow[t]{3}{*}{ HS 200-2 } & \multirow[t]{3}{*}{ Bypass } & \multirow[t]{3}{*}{4} \\
\hline & TIC 112-2 & $\mathrm{HH}$ & & & \\
\hline & TIC 112-2 & $\mathrm{LL}$ & & & \\
\hline \multirow[t]{4}{*}{8} & \multicolumn{2}{|c|}{ Operator Initiation } & \multirow[t]{4}{*}{ HS 300-7 } & \multirow[t]{4}{*}{ Bypass } & \multirow[t]{4}{*}{4} \\
\hline & 니 300-4 & $\mathrm{HH}$ & & & \\
\hline & YA 302-5 & Fail & & & \\
\hline & AlC 302-2 & $\mathrm{HH}$ & & & \\
\hline \multirow[t]{2}{*}{9} & $\mathrm{FI} 302-4$ & $\mathrm{LL}$ & HS 302-5 & Stop & \multirow[t]{2}{*}{4} \\
\hline & LI $300-4$ & $L L$ & HS 300-7 & Bypass & \\
\hline \multirow[t]{5}{*}{10} & TI 010-3 & $\mathrm{HH}$ & \multirow[t]{5}{*}{ HS 020-2 } & \multirow[t]{5}{*}{ Stop } & \multirow[t]{5}{*}{4} \\
\hline & TI 020-3 & $\mathrm{HH}$ & & & \\
\hline & TI 100-19 & $\mathrm{HH}$ & & & \\
\hline & AlC $300-6$ & LL & & & \\
\hline & AlC 302-2 & $\mathrm{HH}$ & & & \\
\hline 11 & FIC 100-7 & LL & HS 020-1 & Stop & 4 \\
\hline 12 & FIC $100-8$ & LL & HS $022-1$ & Stop & 4 \\
\hline
\end{tabular}


Table 2-9 (continued). Interlock Description

\begin{tabular}{|c|c|c|c|c|c|}
\hline No. & Initiation & Condition & Output & Action & $\begin{array}{c}\text { Interlock } \\
\text { Class }\end{array}$ \\
\hline 13 & FIC 100-9 & LL & HS 024-1 & Stop & 4 \\
\hline \multirow[t]{2}{*}{14} & \multirow{2}{*}{\multicolumn{2}{|c|}{ Operator Initiation }} & HS 200-2 & Bypass & \multirow[t]{2}{*}{4} \\
\hline & & & HS 200-3 & Bypass & \\
\hline
\end{tabular}

Key:

$H H=$ high-high

$\mathrm{LL}=$ low-low

Table 2-10. Interlock Classifications

\begin{tabular}{|c|l|l||}
\hline \hline Interlock Class & \multicolumn{1}{|c|}{ Hazard Description } & \multicolumn{1}{|c|}{ Level of Protection Required } \\
\hline 1 & $\begin{array}{l}\text { Loss of life or major property damage } \\
\text { outside plant boundary. }\end{array}$ & $\begin{array}{l}\text { Hard-wired with redundant instrumentation, } \\
\text { diverse types. }\end{array}$ \\
\hline $2^{\circ}$ & $\begin{array}{l}\text { Loss of life or major property damage } \\
\text { within plant boundary. }\end{array}$ & $\begin{array}{l}\text { Hard-wired with redundant instrumentation, } \\
\text { may be same type. }\end{array}$ \\
\hline 3 & Property damage or loss of production. & Hard-wired, single instrument. \\
\hline 4 & Process desirability. & Software \\
\hline
\end{tabular}

\subsection{Electrical}

The electrical service connection to the PBR/SDP MTU will be supplied in accordance with the utility requirements noted in Section 2.2.2 of this report. The electrical classification of the MTU, excluding any utilities which may be sited outdoors, will be National Electrical Code Class 1, Division 2, Group D. All motors will be specified with a 1.15 service factor or for continuous operation at $7,500 \mathrm{ft}$ of elevation. The PBR/SDP Electrical Distribution is presented in Figure A-8.

\subsection{Instrument List}

Table 2-11 lists the instruments required in the PBR/SDP MTU design. Instruments which interface with the PLC are identified as AI (analog input), AO (analog output), DI (digital input), or DO (digital output). The control logic is presented in the P\&IDs (Appendix A). 
Table 2-11. Instrument List

\begin{tabular}{|c|c|c|c|c|c|c|c|}
\hline Tag No. & Description & Range & Al & AO & D) & DO & $\begin{array}{c}\text { Drawing } \\
\text { No. }\end{array}$ \\
\hline PI 002-1 & P-002 Discharge Pressure Gauge & $0-100$ psi & & & & & E03456 \\
\hline PCV 002-2 & P-002 Air Supply Pressure Regulator & $0-60$ psig & & & & & E03456 \\
\hline PI 002-2 & P-002 Air Supply Pressure Gauge & $0-100$ psi & & & & & E03456 \\
\hline EV 002-3 & P-002 Air Supply Shutoff Valve & & & & 1 & 1 & E03456 \\
\hline HS $002-3$ & P-002 Air Supply Shutoff Switch & & & & 1. & 1 & $E 03456$ \\
\hline EV $010-1$ & A-010 Air Supply Shutoff Valve & & & & 1 & 1 & E03456 \\
\hline HS 010-1 & A-010 Air Supply Shutoff Switch & & & & 1 & 1 & E03456 \\
\hline PT 010-2 & T-010 Pressure Transmitter & $0-50$ psi & 1 & & & & E03456 \\
\hline PIC 010-2 & T-010 Pressure Indicator/Controller & Split & & 1 & & & E03456 \\
\hline PCV 010-2A & T-010 Pressure Control Valve (High Pressure) & $2 \mathrm{sctm}$ & & & & & $E 03456$ \\
\hline PCV 010-2 & T-010 Pressure Control Valve (Low Pressure) & & & & & & E03456 \\
\hline TE 010-3 & T-010 Temperature Element & $0-100^{\circ} \mathrm{C}$ & & & & & E03456 \\
\hline$\pi 010-3$ & T-010 Temperature Transmitter & & 1 & & & & $E 03456$ \\
\hline TI 010-3 & T-010 Temperature Indicator & & & 1 & & & E03456 \\
\hline LE $010-4$ & T-010 Level Element & $0-60$ in. & & & & & E03456 \\
\hline LT $010-4$ & T-010 Level Transmitter & & 1 & & & & E03456 \\
\hline LI 010-4 & T-010 Level Indicator & & & 1 & & & E03456 \\
\hline PSE 010-5 & T-010 Relief Rupture Disk & 45 psig & & & & & E03456 \\
\hline $\mathrm{Pl} 010-5$ & T-010 Relief Tell-Tale Gauge & $0-50$ psi & & & & & E03456 \\
\hline PSV 010-5 & T-010 Relief Valve & 50 psig & & & & & E03456 \\
\hline AE 010-6 & $\mathrm{T}-010 \mathrm{pH}$ Meter & $\mathrm{pH} \mathrm{1-14}$ & & & & & E03456 \\
\hline AT $010-6$ & $\mathrm{~T}-010 \mathrm{pH}$ Transmitter & & 1 & & & & E03456 \\
\hline Al 010-6 & T-010 pH Indicator & & & 1 & & & E03456 \\
\hline LE 010-7 & T-010 Level Element & $0-60$ in. & & & & & E03456 \\
\hline LT 010-7 & T-010 Level Transmitter & & 1 & & & & E03456 \\
\hline 니 010-7 & T-010 Level Indicator & & & 1 & & & E03456 \\
\hline FE 010-8 & Total Waste Feed Flow Meter & $0-75 \mathrm{gal} / \mathrm{d}$ & & & & & E03456 \\
\hline FT 010-8 & Total Waste Feed Flow Transmitter & & 1 & & & & $E 03456$ \\
\hline FIC 010-8 & Total Waste Feed Flow Controller & & & 1 & & & E03456 \\
\hline EV 010-10 & T-010 Vent Shutoff Valve & & & & 1 & 1 & E03456 \\
\hline$A E 010-11$ & T-010 Foam Sensor Element & Conductivity & 1 & & & & E03456 \\
\hline AT 010-11 & T-010 Foam Sensor Transmitter & & & 1 & & & E03456 \\
\hline AIC $010-11$ & T-010 Foam Sensor Indicator/Controller & & & & & & E03456 \\
\hline
\end{tabular}


Table 2-11 (continued). Instrument List

\begin{tabular}{|c|c|c|c|c|c|c|c|}
\hline Tag No. & Description & Range. & Al & AO & DI & Do & $\begin{array}{c}\text { Drawing } \\
\text { No. } \\
\end{array}$ \\
\hline LG 010-12 & $T-010$ Sight Glass & & & & & & E03456 \\
\hline HS 020-1 & P-020 Start/Stop Switch & & & & 1 & 1 & E03457 \\
\hline YL 020-1 & P-020 Run Indication & & & & 1 & 1 & E03457 \\
\hline YA 020-1 & P-020 Fall Indication & & & & 1 & 1 & E03457 \\
\hline HS 020-3 & P-020/022/024 Start/Stop Switch & & & & 1 & 1 & $E 03457$ \\
\hline FE 020-2 & $\mathrm{P}-020$ Flow Element & $0-25 \mathrm{gall} / \mathrm{d}$ & 1 & & & & $E 03457$ \\
\hline FT 020-2 & P-020 Flow Transmitter & & & 1 & & & E03457 \\
\hline $\mathrm{Fl} 020-2$ & P-020 Flow Indicator & & & & & & E03457 \\
\hline HS 022-1 & $P-022$ Start/Stop Switch & & & & 1 & 1 & $E 03457$ \\
\hline YL 022-1 & P-022 Run Indication & & & & 1 & 1 & $E 03457$ \\
\hline YA 022-1 & P-022 Fail Indication & & & & 1 & 1 & $E 03457$ \\
\hline FE 022-2 & P-022 Flow Element & $0-25 \mathrm{gal} / \mathrm{d}$ & 1 & & & & E03457 \\
\hline FT 022-2 & P-022 Flow Transmitter & & & 1 & & & $E 03457$ \\
\hline FI 022-2 & $\mathrm{P}-022$ Flow Indicator & & & & & & E03457 \\
\hline HS 024-1 & P-024 Start/Stop Switch & & & & 1 & 1 & E03457 \\
\hline YL 024-1 & P-024 Run Indication & & & & 1 & 1 & E03457 \\
\hline YA 024-1 & P-024 Fail Indication & & & & 1 & 1 & $E 03457$ \\
\hline FE 024-2 & $\mathrm{P}-024$ Flow Element & $0-25 \mathrm{gald}$ & 1 & & & & E03457 \\
\hline FT 024-2 & P-024 Flow Transmitter & & & 1 & & & E03457 \\
\hline FI 024-2 & $\mathrm{P}-024$ Flow Indicator & & & & & & E03457 \\
\hline IC 100-1 & R-100 Zone 1 Heater Controller & $0-20 \mathrm{~kW}$ & & 1 & & & E03457 \\
\hline TE 100-1 & A-100 Zone 1 Temperature Element & $0-1.200^{\circ} \mathrm{C}$ & 1 & & & & E03457 \\
\hline IIC 100-1 & R-100 Zone 1 Temperature Indicator/Controller & & & 1 & & & $E 03457$ \\
\hline IC 100-2 & R-100 Zone 2 Heater Controller & $0-20 \mathrm{~kW}$ & & 1 & & & $E 03457$ \\
\hline TE 100-2 & R-100 Zone 2 Temperature Element & $0-1.200^{\circ} \mathrm{C}$ & 1 & & & & E03457 \\
\hline TIC 100-2 & R-100 Zone 2 Temperature Indicator/Controller & & & 1 & & & E03457 \\
\hline IC 100-3 & R-100 Zone 3 Heater Controller & $0-20 \mathrm{~kW}$ & & 1 & & & E03457 \\
\hline TE 100-3 & R-100 Zone 3 Temperature Element & $0-1.200^{\circ} \mathrm{C}$ & 1 & & & & E03457 \\
\hline TIC 100-3 & R-100 Zone 3 Temperature Indicator/Controller & & & 1 & & & E03457 \\
\hline IC $100-4$ & R-100 Zone 4 Heater Controller & $0-20 \mathrm{~kW}$ & & 1 & & & E03457 \\
\hline TE $100-4$ & R-100 Zone 4 Temperature Element & $0-1,200^{\circ} \mathrm{C}$ & 1 & & & & E03457 \\
\hline TIC 100-4 & R-100 Zone 4 Temperature Indicator/Controller & & & 1 & & & E03457 \\
\hline FE 100-5 & R-100 Air Flow Element No. 1 & $0-20 \mathrm{scfm}$ & 1 & & & & E03457 \\
\hline FT 100-5 & R-100 Nozzle Air Flow Transmitter No. 1 & & & 1 & & & E03457 \\
\hline
\end{tabular}


Table 2-11 (continued). Instrument List

\begin{tabular}{|c|c|c|c|c|c|c|c|}
\hline Tag No. & Deseription & Range & Al & AO & DI & DO & $\begin{array}{c}\text { Drawing } \\
\text { No. }\end{array}$ \\
\hline FIC 100-5 & R-100 Nozzle Air Flow Indicator/Controller No. 1 & & & & & & $E 03457$ \\
\hline FE 100-6 & R-100 Nozzle Air Flow Element No. 2 & $0-20 \mathrm{scfm}$ & 1 & & & & E03457 \\
\hline FT 100-6 & R-100 Nozzle Air Flow Transmitter No. 2 & & & 1 & & & E03457 \\
\hline FIC 100-6 & R-100 Nozzle Air Flow Indicator/Controller No. 2 & & & & & & $E 03457$ \\
\hline FE 100-7 & R-100 Nozzle Air Flow Element No. 3 & $0-20$ scfm & 1 & & & & E03457 \\
\hline FT 100-7 & R-100 Nozzle Air Flow Transmitter No. 3 & & & 1 & & & E03457 \\
\hline FIC 100-7 & R-100 Nozzle Air Flow Indicator/Controller No. 3 & $0-20 \mathrm{scfm}$ & & & & & E03457 \\
\hline PT 100-8 & R-100 Inlet Pressure Transmitter & & 1 & & & & E03457 \\
\hline PIC 100-8 & R-100 Inlet Pressure Indicator/Controller & $\begin{array}{l}0-50 \text { in. water } \\
\text { vacuum }\end{array}$ & & 1 & & & E03457 \\
\hline PSE 100-10 & R-100 Relief Rupture Disk & 3 psig & & & & & E03457 \\
\hline PSH 100-10 & R-100 Relief Rupture Disk Burst Indicator & & & & 1 & & E03457 \\
\hline EV 100-11 & R-100 Air Shutoff Valve & & & & 1 & 1 & $E 03457$ \\
\hline FE 100-11 & R-100 Total Air Flow Element & $0-50 \mathrm{scfm}$ & 1 & & & & E03457 \\
\hline FT 100-11 & R-100 Total Air Flow Transmitter & & & 1 & & & E03457 \\
\hline $\mathrm{FIC100-11}$ & R-100 Total Air Flow Indicator/Controller & & & & & & E03457 \\
\hline TE 100-12 & R-100 Outlet Temperature Element & $0-1,200^{\circ} \mathrm{C}$ & 1 & & & & E03457 \\
\hline TI 100-12 & R-100 Outlet Temperature Indicator & & & 1 & & & E03457 \\
\hline PDT 100-13 & R-100 Pressure Differential Transmitter & & 1 & & & . & $E 03457$ \\
\hline PDI 100-13 & R-100 Pressure Differential Indicator & $0-50$ in. water & & 1 & & & E03457 \\
\hline PI 100-14 & R-100 Outlet Pressure Gauge & $\begin{array}{l}0-50 \text { in. water } \\
\text { vacuum }\end{array}$ & & & & & E03457 \\
\hline PT 100-15 & R-100 Air Supply Pressure Transmitter & & 1 & & & & E03457 \\
\hline PI 100-15 & R-100 Air Supply Pressure Indicator & $0-20$ psi & & 1 & & & E03457 \\
\hline TE 100-16 & R-100 Midzone Temperature Element No. 1 & $0-1,200^{\circ} \mathrm{C}$ & 1 & & & & E03457 \\
\hline TI 100-16 & R-100 Midzone Temperature Indicator No. 1 & & & 1 & & & E03457 \\
\hline TE 100-17 & R-100 Midzone Temperature Element No. 2 & $0-1,200^{\circ} \mathrm{C}$ & 1 & & & & E03457 \\
\hline $\mathrm{TI} 100-17$ & R-100 Midzone Temperature Indicator No. 2 & & & 1 & & & E03457 \\
\hline TE 100-18 & R-100 Midzone Temperature Element No. 3 & $0-1,200^{\circ} \mathrm{C}$ & 1 & & & & E03457 \\
\hline TI 100-18 & R-100 Midzone Temperature Indicator No. 3 & & & 1 & & & E03457 \\
\hline TIC 100-19 & $\begin{array}{l}\text { R-100 Maximum Temperature } \\
\text { Indicator/Controller }\end{array}$ & $0-1,200^{\circ} \mathrm{C}$ & & 1 & & & E03457 \\
\hline FE 110-1 & Quench Water Flow Meter & $0-25 \mathrm{lb} / \mathrm{h}$ & & & & & E03457 \\
\hline FT 110-1 & Quench Water Flow Transmitter & & 1 & & & & E03457 \\
\hline FIC 110-1 & Quench Water Flow Indicator/Controller & & & 1 & & & $E 03457$ \\
\hline
\end{tabular}


Table 2-11 (continued). Instrument List

\begin{tabular}{|c|c|c|c|c|c|c|c|}
\hline Tag No. & Description & Range & A! & AO & $\mathrm{Dl}$ & Do & $\begin{array}{c}\text { Drawing } \\
\text { No. }\end{array}$ \\
\hline TE 110-2 & E-110 Outlet Temperature Element & $0-600^{\circ} \mathrm{C}$ & 1 & & & & E03457 \\
\hline TIC $110-2$ & E-110 Outlet Temperature Indicator/Controller & & & 1 & & & E03457 \\
\hline EV $110-3$ & Quench Water Flow Shutoff Valve & & & & 1 & 1 & $E 03457$ \\
\hline FE 112-1 & E-112 Cooling Water Flow Meter & $0-25 \mathrm{lb} / \mathrm{m}$ & & & & & E03457 \\
\hline FT 112-1 & E-112 Cooling Water Flow Transmitter & & 1 & & & & $E 03457$ \\
\hline FIC 112-1 & E-112 Cooling Water Flow Indicator/Controller & & & 1 & & & E0345ं \\
\hline TE 130-3 & E-112 Outlet Temperature Element & $0-200^{\circ} \mathrm{C}$ & 1 & & & & E03457 \\
\hline TIC 130-3 & E-112 Outlet Temperature Indicator/Controller & & & 1 & & & $E 03457$ \\
\hline PI 112-3 & E-112 Outlet Pressure indicator & $\begin{array}{l}0-100 \text { in. water } \\
\text { vacuum }\end{array}$ & & 1 & & & E03457 \\
\hline PSV $112-4$ & E-112 Cooling Water Relief Valve & 50psig & & & & & E03457 \\
\hline AE 112-5 & $\mathrm{E}-112$ Outlet $\mathrm{CO} / \mathrm{CO}_{2}$ Analyzer. Element & $0-5 \%(v / v)$ & 1 & & & & E03457 \\
\hline AT $112-5$ & E-112 Outlet $\mathrm{CO} / \mathrm{CO}_{2}$ Analyzer Transmitter & & & 1 & & & E03457 \\
\hline Al 112-5 & E-112 Outlet $\mathrm{CO} / \mathrm{CO}_{2}$ Analyzer Indicator & & & & & & E03457 \\
\hline PDT 120-1 & F-120 Pressure Differential Transmitter & $0-10$ in. water & 1 & & & & $E 03488$ \\
\hline PDI 120-1 & F-120 Pressure Differential Indicator & & & 1 & & & E03488 \\
\hline PDI $130-1$ & F-130A Local Pressure Differential Indicator & $0-10$ in. water & & & & & E03488 \\
\hline PDI 130-2 & F-130B Local Pressure Differential Indicator & $0-10$ in. water & & & & & E03488 \\
\hline HS 200-2 & SDP Bypass Hand Switch & & & & 1 & 1 & E0348B \\
\hline HS 200-3 & SDP/Filter Inversion Hand Switch & & & & 1 & 1 & E0348B \\
\hline FE 201-1 & R-201 Inlet Flow Meter & $0-20 \mathrm{scfm}$ & & & & & $E 03488$ \\
\hline FT 201-1 & R-201 Inlet Flow Transmitter & & 1 & & & & E03488 \\
\hline FIC 201-1 & R-201 Inlet Flow Indicator/Controller & & & 1 & & & E03488 \\
\hline FE 202-1 & R-202 Inlet Flow Meter & $0-20 \mathrm{scfm}$ & & & & & E03488 \\
\hline FT 202-1 & R-202 Inlet Fiow Transmitter & & 1 & & & & E03488 \\
\hline FIC 202-1 & R-202 Inlet Flow Indicator/Controller & & & 1 & & & E03488 \\
\hline FE 203-1 & R-203 Inlet Flow Meter & $0-20 \mathrm{scfm}$ & & & & & E03488 \\
\hline FT 203-1 & R-203 Inlet Flow Transmitter & & 1 & & & & $E 03488$ \\
\hline FIC 203-1 & R-203 Inlet Flow Indicator/Controller & & & 1 & & & E03488 \\
\hline FE 204-1 & R-204 Inlet Flow Meter & $0-20 \mathrm{sctm}$ & & & & & E03488 \\
\hline FT 204-1 & R-204 Inlet Flow Transmitter & & 1 & & & & E03488 \\
\hline FIC 204-1 & R-204 Inlet Flow Indicator/Controller & & & 1 & & & E03488 \\
\hline TE 201-2 & SDP Outlet Pipinq Temperature Element & $0-300^{\circ} \mathrm{F}$ & 1 & & & & E03458 \\
\hline
\end{tabular}


Table 2-11 (continued). Instrument List

\begin{tabular}{|c|c|c|c|c|c|c|c|}
\hline Tag No. & Description & Range & Al & AO & DI & Do & $\begin{array}{c}\text { Drawing } \\
\text { No. }\end{array}$ \\
\hline TIC 201-2 & $\begin{array}{l}\text { SDP Outlet Piping Temperature } \\
\text { Indicator/Controller }\end{array}$ & & & 1 & & & E03458 \\
\hline IC201-2 & $\begin{array}{l}\text { SDP Outlet Piping Heat Tracing Power } \\
\text { Controller }\end{array}$ & & & & & & E03458 \\
\hline PDT 300-1 & S-300 Pressure Differential Transmitter & & 1 & & & & E03458 \\
\hline PDI 300-1 & S-300 Pressure Differential Indicator & $0-10$ in. water & & 1 & & & E03458 \\
\hline TE 300-2 & S-300 Outlet Temperature Element & $0-200^{\circ} \mathrm{C}$ & 1 & & & & E03458 \\
\hline$T 1300-2$ & S-300 Oullet Temperature Indicator & & & 1 & & & E03458 \\
\hline PT 300-3 & S-300 Oullet Pressure Element & & 1 & & & & E03458 \\
\hline $\mathrm{Pl} 300-3$ & S-300 Outlet Pressure Indicator & $\begin{array}{l}0-100 \text { in. water } \\
\text { vacuum }\end{array}$ & & 1 & & & E03458 \\
\hline EV $300-4$ & S-300 Process Water Supply Shutoff Valve & & & & 1 & 1 & E03458 \\
\hline LT 300-4 & S-300 Level Transmitter & & 1 & & & & $E 03458$ \\
\hline LL $300-4$ & S-300 Level Indicator & & & 1 & & & E03458 \\
\hline LG 300-5 & S-300 Level Sight Glass & $0-24$ in. & & & & & E03458 \\
\hline$A E 300-6$ & $\mathrm{~S}-300 \mathrm{pH}$ Meter & pH 1-14 & & & & & E03458 \\
\hline AT $300-6$ & $\mathrm{~S}-300 \mathrm{pH}$ Transmitter & & 1 & & & & E03458 \\
\hline AIC 300-6 & $\mathrm{S}-300 \mathrm{pH}$ Indicator/Controller & & & 1 & & & E03458 \\
\hline HS 300-7 & Scrubber Bypass Hand Switch & & & & 1 & 1 & E03458 \\
\hline PSV 300-9 & S-300 Relief Valve & 3 psig & & & & & E03458 \\
\hline AE $300-10$ & Vent Gas $\mathrm{CO} / \mathrm{CO}_{2}$ Analyzer & & 1 & & & & $E 03458$ \\
\hline AT $300-10$ & Vent Gas $\mathrm{CO} / \mathrm{CO}$, Transmitter & & & 1 & & & E03458 \\
\hline Al $300-10$ & Vent Gas $\mathrm{CO} / \mathrm{CO}_{2}$ Indicator & & & & & & E03458 \\
\hline PI 302-1 & P-302 Discharge Pressure Gauge & $0-30$ psig & & & & & $E 03458$ \\
\hline AE 302-2 & S-300 Conductivity Meter & $\begin{array}{l}0-300 \\
\text { mmhos/cm }\end{array}$ & & & & & E03458 \\
\hline AT 302-2 & S-300 Conductivity Transmitter & & 1 & & & & E03458 \\
\hline AIC 302-2 & S-300 Conductivity Indicator/Controller & & & 1 & & & $E 03458$ \\
\hline EV 302-2 & S-300 Blowdown Valve & & & & 1 & 1 & E03458 \\
\hline HS 302-2 & EV 302-2 Cutout Hand Switch & & & & 1 & 1 & $E 03458$ \\
\hline FE 302-4 & P-302 Circulation Flow Meter & $0-4 \mathrm{gal} / \mathrm{min}$ & & & & & E03458 \\
\hline FT 302-4 & P-302 Circulation Flow Transmitter & & 1 & & & & E03458 \\
\hline FI 302-4 & P-302 Circulation Flow Indicator & & & 1 & & & $E 03458$ \\
\hline HS 302-5 & P-302 Start/stop Switch & & & & 1 & 1 & $E 03458$ \\
\hline YL 302-5. & P-302 Run Indicator & & & & 1 & 1 & $E 03458$ \\
\hline
\end{tabular}


Table 2-11 (continued). Instrument List

\begin{tabular}{|c|c|c|c|c|c|c|c|}
\hline Tag No. & Description & Range & Al & AO & DI & DO & $\begin{array}{c}\text { Drawing } \\
\text { No. }\end{array}$ \\
\hline YA 302-5 & P-302 Fail Indicator & & & & 1 & 1 & E03458 \\
\hline WE $302-6$ & Scrubber Blowdown Drum Weight Cell & $0-600 \mathrm{lb}$ & & & & & E03458 \\
\hline WT 302-6 & Scrubber Blowdown Drum Weight Transmitter & & 1 & & & & E03458 \\
\hline WI 302-6 & Scrubber Blowdown Drum Weight Indicator & & & 1 & & & E03458 \\
\hline PDI 306-1 & F-306 Differential Pressure & $0-5$ psi & & & & & E03458 \\
\hline PDIC 100-14 & MTU Pressure Differential Indicator/Controller & $0-100$ in. water & & 1 & & & E03489 \\
\hline FSL 140-1 & E-140 Cooling Water Low-Flow Switch & & & & & 1 & E03489 \\
\hline PSV 140-2 & E-140 Cooling Water Relief Valve & $50 \mathrm{psig}$ & & & & & E03489 \\
\hline PT $140-3$ & Relief Header Pressure Transmilter & $0-10$ psig & 1 & & & & E03489 \\
\hline Pl 140-3 & Relief Header Pressure Indicator & & & 1 & & & E03489 \\
\hline PDI 144-1 & F-144 Pressure Differential Indicator & $0-10$ in. water & 1 & 1 & & & E03489 \\
\hline PT $300-8$ & B-320 Suction Pressure Transmitter & $\begin{array}{l}0-100 \text { in. water } \\
\text { vacuum }\end{array}$ & 1 & & & & E03489 \\
\hline PI 300-8 & B-320 Suction Pressure Indicator & & & 1 & & & E03489 \\
\hline HS 320-1 & B-320 Start/Stop Switch & & & & 1 & 1 & E03489 \\
\hline YL 320-1 & B-320 Run indicator & & & & 1 & 1 & E03489 \\
\hline YA 320-1 & B-320 Fail Indicator & & & & 1 & 1 & E03489 \\
\hline ZC 320-2 & B-320 Inlet Vane Positioner & & & & & & E03489 \\
\hline AE 320-3 & Process Vent VOC Meter & & & & & & E03489 \\
\hline AlT 320-3 & Process Vent VOC Indicator/Transmitter & & 1 & & & & E03489 \\
\hline Al 320-3 & Process Vent voc Indicator & & & 1 & & & $E 03489$ \\
\hline EV $320-4$ & Process Vent VOC Shutoff Valve & & & & 1 & 1 & E03489 \\
\hline HS 304-1 & P-304 StartStop Switch & & & & 1 & 1 & E03459 \\
\hline YL 304-1 & P-304 Run Indicator & & & & 1 & 1 & E03459 \\
\hline YA 304-1 & P-304 Fail Indicator & & & & 1 & 1 & E03459 \\
\hline WE 304-2 & Sodium Hydroxide Drum Weight Cell & $0-1,000 \mathrm{lb}$ & & & & & E03459 \\
\hline WT 304-2 & Sodium Hydroxide Drum Weight Transmitter & & 1 & & & & E03459 \\
\hline WI 304-2 & Sodium Hydroxide Drum Weight Indicator & & & 1 & & & $E 03459$ \\
\hline HS 402-1 & P-402 Start/Stop Switch & & & & 1 & 1 & $E 03459$ \\
\hline YL 402-1 & P-402 Run indicator & & & & 1 & 1 & E03459 \\
\hline YA 402-1 & $P-402$ Fail Indicator & & & & 1 & 1 & E03459 \\
\hline HS 410-1 & P-410 Star/Stop Switch & & & & 1 & 1 & E03459 \\
\hline YL 410-1 & P-410 Run Indicator & & & & 1 & 1 & E03459 \\
\hline YA 410-1 & $P-410$ Fail Indicator & & & & 1 & 1 & E03459 \\
\hline
\end{tabular}


Table 2-11 (continued). Instrument List

\begin{tabular}{|c|c|c|c|c|c|c|c|}
\hline Tag No. & Description & Range & Al & AO & DI & Do & $\begin{array}{c}\text { Drawing } \\
\text { No. }\end{array}$ \\
\hline HS 430-1 & P-430 Start/Stop Switch & & & & 1 & 1 & E03459 \\
\hline YL 430-1 & P-430 Run Indicator & - & & & 1 & 1 & E03459 \\
\hline YA 430-1 & P-430 Fail Indicator & & & & 1 & 1 & E03459 \\
\hline PCV 450-1 & Nitrogen Supply Header Pressure Regulator & 0-20 psig & & & & & $E 03459$ \\
\hline PSV 450-2 & Nitrogen Supply Header Relief Valve & 20 psig & & & & & E03459 \\
\hline Total & & & 49 & 56 & 40 & 43 & \\
\hline
\end{tabular}

Key:

AI = analog input

$A O=$ analog output

DI = digital input

$\mathrm{DO}=$ digital output

\subsection{Modular Design}

Skids for modular transport of the PBR/SDP MTU will be restricted to $8 \mathrm{ft}$ wide $\times 10 \mathrm{ft}$ long $\times 11.5 \mathrm{ft}$ high. When fully assembled, the maximum height of the MTU must not exceed $18 \mathrm{ft}$. Each skid will be required to fit on a standard "low boy" truck bed without requiring special height or width clearance restrictions.

Each skid will consist of process equipment mounted on a painted, carbon-steel, skid-mounted frame that will conform to DOT regulations for the transportation of mobile chemical equipment. The skid-mounted frames will be designed for all operating and seismic loads in accordance with the American Institute of Steel Construction (AISC) "Specifications for Structural Steel Buildings, Allowable Stress Design and Plastic Design," (AISC 1989). Seismic loading will be evaluated using the static force procedure.

Temporary loading conditions due to commissioning, decommissioning, and transport will be considered. Although lifting the skids with cranes is not anticipated, each skid will be equipped with "pick-points" for lifting if necessary.

\section{Radiological Shipment}

The PBR/SDP MTU will be designed with the goal of being transported and labeled as "Radioactive Material, Excepted Package - Limited Quantity (of material)" as defined in 49 CFR 173.443. The DOT requirements for shipping the PBR/SDP MTU in this manner are

- The unit must be RCRA empty (less than 3 percent full of liquid).

- The unit must have less than $0.5 \mathrm{mrem} / \mathrm{h}$ exposure on the external surface.

- The removable contamination on the external surfaces must be less than those levels specified in 49 CFR 173.443.

- The unit must contain less than 15 grams of uranium-235.

- The unit must be secured during shipment so that no leakage can occur. 
The surface contamination inside the PBR/SDP MTU is not regulated if being shipped "limited quantity." However, the materials of construction for the MTU will be chosen so that the MTU is easily decontaminated. Construction will include equipping the tanks with portals, manholes, etc., to allow access for internal inspection and radiological surveys. In addition, all wetted surface materials upstream of the SDP Inlet HEPA Filters (F-130A and F-130B) will be polished to a Roughness Height Index Value of 4 as outlined in ANSI/ASME B46.1. 


\subsection{Feed Preparation Requirements}

The preliminary hazards and operability (HAZOP) analysis of the PBR/SDP MTU (see Section 7.9 and Appendix $C$ ) identified the waste transfer operation as potentially the most troublesome area, because of possible personnel exposure issues and because of the unpredictability of the wastes, which may contain multiple immiscible layers, high concentrations of solids, tars and other gummy, high-viscosity materials, or all of the above at once. At this time, waste characterization is incomplete, making determination of the level of protection and/or pretreatment required during operation of the PBR/SDP MTU problematic. Protection and pretreatment options will have to be evaluated during the detailed design process. Use of a drum unloading glovebox, similar in concept to that being built for the VAC*TRAX thermal desorption MTU may be the most practical solution for this function.

In general, the PBR/SDP MTU can accept liquid feed streams of virtually any composition, from 100 percent hydrocarbon oils to 100 percent water. The MTU also can accept slurries containing fine solids, provided that the particle size is less than $1 / 8$ in. Wastes slated for treatment in the PBR/SDP MTU will be filtered as they are unloaded from the waste drums to remove coarse solids by passing the waste feed through the Strainer (F-004). This Y-type strainer assembly with a 1/8-in. (maximum) screen will remove solids that might otherwise plug the spray nozzles.

Feeds with a $\mathrm{pH}$ of less than 3 or greater than 11 potentially can damage the metallurgy of the PBR $(\mathrm{R}-100)$. Therefore, the $\mathrm{pH}$ of the waste feed will be adjusted in the Waste Feed Tank $(\mathrm{T}-010)$ by adding sodium hydroxide or sulfuric acid when appropriate. Because $\mathrm{pH}$ adjustment is not expected to be a routine operation, addition of sulfuric acid or sodium hydroxide will be initiated and terminated manually by starting and stopping the appropriate pump.

Because the primary function of the PBR/SDP MTU is treatment of organic mixed wastes, it is possible that some wastes slated for treatment with this technology may include tarry or gummy liquids of high viscosity. Such liquids will not atomize in the spray nozzles and, thus, would not be suitable for treatment with the present PBR technology. In the absence of detailed information about the wastes, no explicit provision has been made in the DDR for pretreatment of high-viscosity liquids. These liquids potentially could be treated by mixing them with a low-viscosity solvent and pumping the resultant mixture into the Waste Feed Tank ( $\mathrm{T}-010)$. Provisions for such an operation have not been included in this DDR, but may be addressed during the detailed design process as part of the greater feed preparation issue discussed above. 
This page intentionally blank

) 


\subsection{Waste Acceptance Criteria}

The PBR/SDP MTU will be designed for treatment of liquid mixed organic and aqueous waste streams containing RCRA hazardous compounds. PBR/SDP technology has also been demonstrated on surrogates for waste streams containing TSCA wastes (e.g., PCBs), although no such wastes are presently slated for treatment with the MTU.

PBR/SDP is a robust and "forgiving" technology that can successfully treat a wide variety of liquid organic and aqueous waste streams. However, wastes exhibiting certain characteristics, as detailed below, are not appropriate for treatment with PBR/SDP technology. Wastes that will be excluded are those exhibiting any of the following properties or characteristics.

- Reactivity: The waste must not contain pyrophorics or explosives (40 CFR 261).

- Criticality: Radionuclide content shall be verified to limit the total radionuclide inventory within the PBR/SDP system to no more than one-tenth the critical mass.

- Pathogenic waste or etiological agents. (Wastes with these characteristics should not be part of mixed-waste inventory.)

Other waste characteristics, while not necessarily sufficient to disqualify a waste stream from treatment with PBR/SDP, can cause operability problems in the MTU. The remainder of this section deals with waste characteristics in these "gray areas" that may or may not cause specific wastes to be excluded from treatment with PBR/SDP.

Gaseous materials: PBR/SDP technology is capable of destroying gas-phase organics. However, because the PBR technology has only been demonstrated on liquids, the design presented in this DDR does not have the capability for opening gas cylinders and metering the gas flow into the PBR. Such capability may be retrofitted to the MTU after it is operational, but is outside the scope of this DDR.

Slurries: The PBR/SDP technology has demonstrated the ability to treat slurries containing plastics and other organic solids (LANL 1994), provided that the particle size does not exceed 1/8 in. Larger particles will be removed in the Strainer (F-004). However, the solids-holding capacity of F-004 is limited and it should not be expected to remove large quantities of solids. Streams containing large amounts of coarse solids should be prescreened by the sites or treated with other technologies.

Mercury: Four of the six waste streams currently slated for PBR/SDP treatment, including both LANL wastes and two of the four PTX wastes, contain mercury (RCRA waste code D009). D009 is the only RCRA waste code assigned to PTX TG 1.3, a relatively small waste stream containing only $1.23 \mathrm{~m}^{3}$ or 325 gal. The pilot PBR/SDP unit has never been tested on mercury and the disposition of mercury in the process is uncertain. Vapor-phase mercury would condense in the offgas stream and would presumably deposit on equipment surfaces. Mercury oxides could conceivably pass through the PBR $(R-100)$ and SDP and would precipitate in the Acid-Gas Scrubber (S-300), if it is being used, or in the offgas piping.

Compatibility: The Waste Feed Tank $(T-010)$ has a working capacity of about 175 gal, or about three full 55-gal drums. To avoid operational problems and potential releases, it is important to avoid mixing incompatible wastes (e.g., water-reactive wastes with aqueous wastes) in T-010. The waste characterization process should include this consideration. 
Tritium: As detailed in Section 1.2, tritium will be converted into tritiated water in the PBR/SDP MTU. This conversion does not pose a problem for the technology; but, because most of the tritium will ultimately be vented to the atmosphere in the form of tritiated water, site permits need to address tritium emissions.

High-Viscosity Liquids: High-viscosity liquids have the potential to plug the atomizing nozzles or atomize poorly and unevenly into the bed (Section 3.0.). The design of the atomizing nozzles will include guidance as to the maximum viscosity that can be atomized. High-viscosity liquids would not necessarily be excluded from treatment with PBR/SDP if they can be pretreated (e.g., mixed with a solvent) to reduce the viscosity. However, such pretreatment would represent a process in itself and is outside the scope of this DDR, so no provisions for it have been made in the design. 


\subsection{Treatment Standards}

The goal of treatment of hazardous waste is to meet the specific treatment standards for the waste and thus allow final disposal of the waste and/or any treatment residuals. Treatment standards for hazardous wastes are specific requirements that must be met before a hazardous waste may be land disposed (40 CFR 268 Subpart D). The specific treatment requirements for a given waste are dependent on the nature of the waste and its RCRA hazardous-waste code. Specific treatment standards for RCRA hazardous wastes are identified as either numerical concentration limits for specific hazardous constituents or treatment with specific treatment technologies (40 CFR 268.40).

Treatment standards apply to the hazardous waste itself and to any solid or liquid residuals that result from treatment. With the PBR/SDP technology, the waste itself is consumed in the treatment. The residuals to which numerical waste treatment standards would apply are the scrubber blowdown liquid and the activated carbon. If these residuals do not meet the treatment standards, they would have to be further treated to meet the treatment standards before they could be land disposed.

Table $5-1$ is a list of the numerical treatment standards for the RCRA hazardous-waste codes identified in the seven waste streams currently slated for treatment with PBR/SDP (Section 1.4). The numerical standards differ depending on whether the residual is classified as a wastewater or a nonwastewater. To qualify as a wastewater, the residual must be a liquid containing less than 1 percent total organic carbon and less than 1 percent total suspended solids. On this basis, considering the high destruction efficiency of the PBR/SDP MTU, the fact that the SDP offgas is filtered upstream of the Acid-Gas Scrubber (S-300) to remove particulates, and that $S-300$ is designed to blow down before precipitation takes place, the scrubber blowdown from the PBR/SDP MTU would be expected to be classified as a RCRA wastewater, and would have to conform to the generally more stringent wastewater standards. The spent activated carbon, a solid, would be considered a nonwastewater. For RCRA waste codes D001 through D003, the treatment standard is deactivation (i.e., chemical removal of the hazardous characteristics, such as neutralization to remove the D002 corrosivity characteristic) with removal of underlying constituents. For Trypan Blue (RCRA waste code U236) and cyanogen bromide (RCRA waste code U246), the treatment standard is incineration.

Table 5-1. RCRA Hazardous-Waste Treatment Standards

\begin{tabular}{|c|l|c|c|}
\hline $\begin{array}{c}\text { RCRA } \\
\text { Waste Code }\end{array}$ & \multicolumn{1}{|c|}{ Constituent } & $\begin{array}{c}\text { Wastewater } \\
\text { Treatment } \\
\text { Standard } \\
\text { (mg/L) }\end{array}$ & $\begin{array}{c}\text { Nonwastewater } \\
\text { Treatment } \\
\text { Standard } \\
\text { (mg/kg) }\end{array}$ \\
\hline D001 & ignitability & Deactivation & Deactivation \\
\hline D002 & corrosivity & Deactivation & Deactivation \\
\hline D003 & reactivity & Deactivation & Deactivation \\
\hline D004 & arsenic & 5 & 5 \\
\hline D006 & cadmium & 1 & 1 \\
\hline D007 & chromium & 5 & 5 \\
\hline D008 & lead & 5 & 5 \\
\hline$D 009$ & mercury & 0.2 & \\
\hline$D 011$ & silver & 5 & 5 \\
\hline D018 & benzene & 0.14 & 10 \\
\hline D019 & carbon tetrachloride & 0.057 & 6 \\
\hline
\end{tabular}


Table 5-1 (continued). RCRA Hazardous-Waste Treatment Standards

\begin{tabular}{|c|c|c|c|}
\hline $\begin{array}{c}\text { RCRA } \\
\text { Waste Code } \\
\end{array}$ & Constituent & $\begin{array}{c}\text { Wastewater } \\
\text { Treatment } \\
\text { Standard } \\
\text { (mg/L) } \\
\end{array}$ & $\begin{array}{c}\text { Nonwastewater } \\
\text { Treatment } \\
\text { Standard } \\
(\mathrm{mg} / \mathrm{kg}) \\
\end{array}$ \\
\hline D022 & chloroform & 0.046 & 6 \\
\hline D028 & 1,2-dichloroethane & 0.21 & 6 \\
\hline $\mathrm{D} 029$ & 1,1-dichloroethylene & 0.025 & 6 \\
\hline D035 & methyl ethyl ketone & 0.28 & 36 \\
\hline $\mathrm{D} 038$ & pyridine & 0.014 & 16 \\
\hline D040 & trichloroethylene & 0.054 & 6 \\
\hline D043 & vinyl chloride & 0.27 & 6 \\
\hline \multirow{32}{*}{$\begin{array}{l}\text { F001 } \\
\text { F002 } \\
\text { F003 } \\
\text { F004 } \\
\text { F005 }\end{array}$} & acetone & 0.28 & 160 \\
\hline & benzene & 0.14 & 10 \\
\hline & n-butyl alcohol & 5.6 & 2.6 \\
\hline & carbon disulfide & 3.8 & $4.8^{b}$ \\
\hline & carbon tetrachloride & 0.057 & 6 \\
\hline & chlorobenzene & 0.057 & 6 \\
\hline & o-cresol & 0.11 & 5.6 \\
\hline & m-cresol & 0.77 & 5.6 \\
\hline & p-cresol & 0.77 & 5.6 \\
\hline & cresol - mixed & 0.88 & 11.2 \\
\hline & cyclohexanone & 0.36 & $0.75^{b}$ \\
\hline & o-dichlorobenzene & 0.088 & 6 \\
\hline & ethyl acetate & 0.34 & 33 \\
\hline & ethyl benzene & 0.057 & 10 \\
\hline & ethyl ether & 0.12 & 160 \\
\hline & isobutyl alcohol & 5.6 & 170 \\
\hline & methanol & 5.6 & $0.75^{b}$ \\
\hline & methylene chloride & 0.089 & 30 \\
\hline & methyl ethyl ketone & 0.28 & 36 \\
\hline & methyl isobutyl ketone & 0.14 & 33 \\
\hline & nitrobenzene & 0.068 & 14 \\
\hline & pyridine & 0.014 & 16 \\
\hline & tetrachloroethylene & 0.056 & 6 \\
\hline & toluene & 0.08 & 10 \\
\hline & 1,1,1-trichloroethane & 0.054 & 6 \\
\hline & 1,1,2-trichloroethane & 0.054 & 6 \\
\hline & 1,1,2-trichloro 1,2,2-trifluoroethane & 0.057 & 30 \\
\hline & trichloroethylene & 0.054 & 6 \\
\hline & trichloromonofluoromethane & 0.02 & 30 \\
\hline & xylenes & 0.32 & 30 \\
\hline & 2-nitropropane & Incineration & Incineration \\
\hline & 2-ethoxyethanol & Incineration & Incineration \\
\hline $\mathrm{U} 002$ & acetone & 0.28 & 160 \\
\hline U019 & benzene & 0.14 & 10 \\
\hline U077 & 1,2-dichloroethane & 0.21 & 6 \\
\hline
\end{tabular}


Table 5-1 (continued). RCRA Hazardous-Waste Treatment Standards

\begin{tabular}{||l|l|c|c|}
\hline $\begin{array}{c}\text { RCRA } \\
\text { Waste Code }\end{array}$ & \multicolumn{1}{|c|}{ Constituent } & $\begin{array}{c}\text { Wastewater } \\
\text { Treatment } \\
\text { Standard } \\
\text { (mg/L) }\end{array}$ & $\begin{array}{c}\text { Nonwastewater } \\
\text { Treatment } \\
\text { Standard } \\
\text { (mg/kg) }\end{array}$ \\
\hline U080 & methylene chloride & 0.089 & 30 \\
\hline U169 & nitrobenzene & 0.068 & 14 \\
\hline U188 & phenol & 0.039 & 6.2 \\
\hline U220 & toluene & 0.08 & 10 \\
\hline U226 & $1,1,1$-trichloroethane & 0.054 & 6 \\
\hline U227 & $1,1,2$-trichloroethane & 0.054 & 6 \\
\hline U228 & trichloroethylene & 0.054 & 6 \\
\hline U236 & Trypan Blue & Incineration & Incineration \\
\hline U246 & cyanogen bromide & Incineration & Incineration \\
\hline
\end{tabular}

"See RCRA regulations (40 CFR 268.40) for mercury treatment standards.

'Units are $\mathrm{mgl}$ L toxicity characteristic leachate process.

In those cases where the treatment standard for a particular hazardous constituent is incineration, the performance requirement for the treatment is based on destruction efficiency of the hazardous constituent. A destruction efficiency of either 99.99 percent or 99.9999 percent of the principal organic hazardous constituents (POHCs) is required by $40 \mathrm{CFR} 264.343$. The higher destruction efficiency, 99.9999 percent, is required for RCRA waste codes F020, F021, F022, F023, F026, and F027. None of the mixed-waste streams currently scheduled for PBR/SDP treatment carries any of these RCRA waste codes.

According to 40 CFR 264.342, the POHCs of interest for a particular site will be specified in the facility's permit. The RCRA regulations are unclear as to whether the specified POHCs must include only those constituents that do not have numerical treatment standards (e.g., Trypan Blue), or if all the hazardous constituents of the waste could be potentially POHCs even if they normally have numerical treatment standards. Interpretations to date suggest that if "incineration" and "nonincineration" wastes are mixed in a single stream, the most stringent treatment standard will apply, so that constituents with numerical treatment standards also may be designated as a POHC and the treatment standard will be the more stringent of either the numerical or the 99.99 percent destruction efficiency.

40 CFR 268.42(b) provides for using an "alternate treatment method" that can achieve "equivalent performance" to the specified technology, which in this case is incineration. Once it is decided to "operate in accordance with incineration standards," none of the numerical treatment standards of any constituent in the waste would be applicable, and the 99.99 percent standard would be applied across the board. Acceptance testing of the PBR/SDP MTU will have to show that the technology can qualify as an "alternate treatment method" to incineration under this definition.

Treatment of PCBs is regulated by TSCA instead of RCRA and the standards are based on incineration. 40 CFR 761.70 contains several criteria for incineration of PCBs. However, the U.S. Environmental Protection Agency (EPA) allows use of other technologies as long as the destruction efficiency of the PCBs is at least 99.9999 percent, which is one of the criteria for incineration of nonliquid PCB wastes specified by 40 CFR 761.70. The destruction efficiency of the PBR/SDP MTU is designed to be at least 99.9999 percent, which will be confirmed during acceptance testing. 
The largest "product" stream from treatment of most wastes in the PBR/SDP MTU is the Acid-Gas Scrubber (S-300) offgas stream, which is vented to the atmosphere. Gas-phase emissions are covered by the air-discharge permits of the individual sites, which limit total tons of emissions, rather than by concentration-based treatment standards. Potential environmental impacts of gas-phase emissions are discussed in Section 6.0. 


\subsection{Environmental Impacts}

\subsection{Byproducts}

The PBR/SDP process produces two byproduct streams in normal operation.

- Scrubber blowdown (Stream 16 on the material balances, Tables 1-1 through 1-3), a salt-water solution that is normally produced only when treating wastes containing halogens.

- Scrubber offgas (Stream 11 on the material balances), which is vented to the atmosphere.

The high destruction efficiency of the PBR/SDP MTU virtually ensures that releases of RCRA and TSCA compounds to the air from the offgas vent will be below regulatory limits. The Process Vent VOC Indicator (AI 320-3) in the offgas stream will provide on-line confirmation of volatile organic compound (VOC) concentrations. Radionuclides should be contained within the PBR (R-100) and the immediate downstream equipment by the use of the two SDP Inlet HEPA Filters (F-130A and F-130B) and should not be released to either of the byproduct streams.

\subsubsection{Scrubber Blowdown}

When nonhalogenated wastes are treated, there is no need to operate the Acid-Gas Scrubber (S-300) and, therefore, no liquid residual waste stream need be produced. During treatment of halogenated wastes, however, S-300 must be operated. Depending on the halogen concentration in the feed organics, the amount of scrubber blowdown can be significant. Table 6-1 shows the amount of scrubber blowdown produced, in units of pounds of blowdown per pound of organic feed, during treatment of a number of chlorinated organics, based on removal of a 20 -percent solution of sodium chloride from S-300. Myristyl chloride is the common name for 1-chlorotetradecane $\left(\mathrm{C}_{14} \mathrm{H}_{29} \mathrm{Cl}\right)$, a chlorinated aliphatic containing 15 percent chlorine by weight. Arachlor is a trade name for PCBs. The last two digits of the Arachlor number give the chlorine content by weight (e.g., Arachlor 1242 contains approximately 42 percent chlorine).

Depending on the chlorine content of the waste, the volume of scrubber blowdown produced from treatment of halogenated wastes can be quite high. For example, one of the most common halogenated solvents to be treated by PBR/SDP is TCE and, as shown in Table 6-1, treatment of TCE will produce over $7 \mathrm{lb}$ of scrubber blowdown for every pound of TCE treated. It is anticipated that all scrubber blowdown will be retained at the site for later volume reduction using the WWE. Even with the action of the WWE taking the residual waste from an initial concentration of 20 percent sodium chloride to a final concentration of 50 percent, the volume of byproduct produced from treatment of highly chlorinated wastes such as TCE still will be significant. However, because the concentration of hazardous constituents in the scrubber blowdown is expected to be well below RCRA standards and radionuclide concentrations are expected to be very low, scrubber blowdown should be disposable as a solidifed salt solution, rather than as a hazardous or mixed waste.

Tritium in the mixed-waste streams to be treated by PBR/SDP will be bound up either as tritiated water or as tritiated organic molecules, which will be converted into tritiated water in the PBR/SDP at very high yields and will thereafter behave like regular water. During treatment of nonhalogenated wastes, all water produced from waste treatment will be vented to the atmosphere as vapor. 
Table 6-1. Scrubber Blowdown from Treatment of Halogenated Organics

\begin{tabular}{||l|c||}
\hline \multicolumn{1}{|c|}{ Compound } & $\begin{array}{c}\text { Blowdown } \\
\text { (lb per lb waste) }\end{array}$ \\
\hline \hline Myristyl chloride & 1.25 \\
\hline Arachlor 1242 & 3.40 \\
\hline Arachlor 1248 & 4.00 \\
\hline Arachlor 1254 & 4.47 \\
\hline Arachlor 1260 & 5.07 \\
\hline 1.1,2-trichloroethane & 6.56 \\
\hline Methylene chloride & 6.87 \\
\hline Trichloroethylene & 7.27 \\
\hline Chloroform & 8.01 \\
\hline
\end{tabular}

When the Acid-Gas Scrubber (S-300) is used, a portion of the water will leave the process as scrubber blowdown and the rest will leave with the vent gases. The split of water between scrubber blowdown and vent gas is a function of the concentration of halogen in the waste. Table 6-2 shows the percentage of the total water produced during waste treatment that leaves the process as scrubber blowdown during treatment of various chlorinated organic compounds (the balance is vented as process vapor). Tritium will exist as tritiated water, so the split of tritium between scrubber blowdown and vent gas should be the same as for other forms of water.

Table 6-2. Percentage of Total Water Removed in Scrubber Blowdown

\begin{tabular}{|l|c|}
\hline \multicolumn{1}{|c|}{ Compound } & $\begin{array}{c}\text { Water in } \\
\text { Blowdown (\%) }\end{array}$ \\
\hline \hline Myristyl chloride & 34.8 \\
\hline Arachlor 1242 & 42.8 \\
\hline Arachlor 1248 & 47.0 \\
\hline Arachlor 1254 & 50.7 \\
\hline Arachlor 1260 & 55.3 \\
\hline 1,1,2-trichloroethane & 76.4 \\
\hline Methylene chloride & 76.3 \\
\hline Trichloroethylene & 83.2 \\
\hline Chloroform & $83.6 \%$ \\
\hline
\end{tabular}


A review of tritium capture requirements (DOE 1995) shows that tritium capture is not needed for the waste streams designated for the PBR/SDP MTU.

The "fate" of radionuclides other than tritium is not known at this point, since no mixed-waste streams have ever been tested in the pilot PBR/SDP units. This DDR assumes that most of the radionuclides will be retained on the packing in the PBR $(R-100)$ and will have to be removed periodically. Two mechanisms have been provided for removal of radionuclides from the bed.

- The "steaming out" process, described in Section 1.2, has been proven to be effective at removing numerous contaminants from the bed. Whether this process will also remove radionuclides remains to be seen. If the process is effective at doing so, the radionuclides would be withdrawn with the condensate at this point.

- If "steaming out" is not effective at removing all radionuclides, the remainder will have to be removed by dumping the bed. The design of $\mathrm{R}-100$ provides for dumping the bed either by unloading the contaminated packing, or by sealing up and removing R-100 entirely, including the alloy shell. In either case, the bed would then be suitable for disposal as radioactive (or potentially mixed if RCRA heavy metals are present) waste using the macroencapsulation process being developed by the DOE-AL Mixed-Waste Treatment Program.

Radionuclides not retained on the packing will be removed in the SDP Inlet HEPA Filters (F-130A and F-130B).

\subsubsection{Vent Emissions}

The chief pollutant of concern in the vent stream is carbon monoxide (CO). Table 6-3 gives the estimated pounds of $\mathrm{CO}$ that will be produced from treatment of each of the waste streams currently slated for PBR/SDP treatment. The waste quantity used for the calculations includes both the current inventory and the estimated 5-year generation. The calculation of $\mathrm{CO}$ that will be produced is based on the following assumptions.

- The specific gravity of halogenated wastes is 1.4 , while the specific gravity of nonhalogenated wastes is 0.8 .

- Halogenated wastes contain 80 percent carbon by weight, while nonhalogenated wastes contain 90 percent carbon.

- 99.9999 percent of the carbon in the waste is converted to carbon dioxide and the balance is converted to $\mathrm{CO}$.

A review of 40 CFR 52 reveals that LANL and SNL/NM are located within Federal Guideline Attainment Areas for all pollutants of concern. The emissions limit for prevention of significant deterioration of air quality for CO, as described in 40 CFR 52.21, is 100 tons per year (ton/yr) of CO. The estimated amount of CO that would be generated while treating the LANL waste streams is $0.22 \mathrm{lb}$, while treatment of the SNL/NM waste stream should generate about one-tenth of this amount. These CO quantities represent much less than 0.001 percent of a permitted $\mathrm{CO}$ source. Therefore, emissions control of the PBR/SDP MTU for control of $\mathrm{CO}$ at these locations is not required. 
Table 6-3. Carbon Monoxide Emissions from Operation of PBR/SDP MTU

\begin{tabular}{||l|r|r|r||}
\hline Waste Stream & $\begin{array}{c}\text { Quantity } \\
\left(\mathrm{m}^{3} \text { waste) }\right.\end{array}$ & $\begin{array}{c}\text { Quantity } \\
\text { (lb waste) }\end{array}$ & Total CO Produced (lb) \\
\hline LA-W 907 & 16.58 & 51,148 & 0.095 \\
\hline LA-W 908 & 14.34 & 25,279 & 0.053 \\
\hline Total LANL & & & 0.148 \\
\hline PTX-TG 1.1 & 0.74 & 1,305 & 0.002 \\
\hline PTX-TG 1.2 & 2.06 & 6.355 & 0.012 \\
\hline PTX-TG 1.3 & 1.55 & 2,732 & 0.006 \\
\hline PTX-TG 1.5 & 0.72 & 1,269 & 0.003 \\
\hline Total PTX & & & 0.023 \\
\hline SNLNM-TG 11 & 2.7 & 8,329 & 0.015 \\
\hline Total SNLNM & & & 0.015 \\
\hline
\end{tabular}

The area surrounding PTX is in a Federal Guideline Attainment Area for CO. The estimated amount of CO that would be generated while treating PTX waste streams is $0.045 \mathrm{lb}$, or about 0.00002 percent of the emissions limit. It is unclear whether or not PTX is within the attainment levels for particulate material less than 10 microns. The presence of the HEPA filter in the offgas line will limit particulate emissions to no more than 0.03 percent of particulates with a particle size of 0.3 microns or greater. Control of criteria pollutants from treatment of wastes with the PBR/SDP MTU at PTX therefore does not seem warranted.

\subsection{National Emission Standards for Hazardous Air Pollutants}

Because the mixed-waste feeds slated for treatment with the PBR/SDP MTU contain radionuclides, 40 CFR 61 Subchapter C, Subpart H, "National Emission Standards for Emissions of Radionuclides Other Than Radon From Department of Energy Facilities," was reviewed. This statute states that, "Emissions of radionuclides to the ambient air from DOE facilities shall not exceed those amounts that would cause any member of the public to receive in any year an effective dose equivalent of $10 \mathrm{mrem} / \mathrm{yr}$." To determine compliance, the facility must implement EPA-approved monitoring and test procedures and computer modeling. The PBR/SDP MTU will not include ventilation emission monitoring for radionuclides because the SDP Inlet HEPA Filters (F-130A and F-130B) will remove all radionuclides that are not trapped in the bed packing. It is assumed that the DOE facilities will monitor, test, and model emissions for radionuclides in accordance with 40 CFR 61.93. 


\subsection{Health and Safety}

When possible, engineering controls will be implemented to eliminate the need for special health and safety requirements. Multiple safety interlocks will be designed into the system to prevent unsafe conditions during operation of the unit. When necessary for specific tasks, appropriate personal protective equipment (PPE) will be specified.

\subsection{Ventilation}

Operation of the MTU poses three primary ventilation hazards.

- Normal operation generates scrubber offgas, a high-temperature $\left(120^{\circ} \mathrm{C}\right.$ nominal) vapor stream. This stream should contain air, carbon dioxide, and water vapor; concentrations of organics should be extremely low.

- During waste transfer from drums to the Waste Feed Tank ( $T-010)$, the drums of hazardous liquid are open and venting hazardous vapors.

- The Acid-Gas Scrubber (S-300) is blown down into an open drum. The hot salt solution will vent steam when it is exposed to the atmosphere.

The detailed design must address provisions for waste unloading, for containing chemical emissions, and for ventilation of the PBR/SDP MTU in a safe and controlled manner.

\subsection{Radioactive Hazards}

The suspected radioactive constituents of the waste streams to be treated with PBR/SDP MTU are uranium, plutonium, thorium, tritium, and cesium-137. Total quantities of radioactive material are unknown. It is expected that most of the radionuclides (with the exception of tritium) will be collected in the packed bed and that the packed bed will have to be cleaned before criticality limits are approached. If the bed packing is dumped from the bed (rather than the entire bed being removed and encapsulated), radioactive emission controls will be in effect during the work. The same will apply to any work on piping and equipment upstream of, and including, the SDP Inlet HEPA Filters (F-130A and F-130B).

Based on a preliminary discussion with Tom McLaughlin (LANL 1996b), the criticality specialist at LANL, criticality is not expected to be an issue with the PBR/SDP MTU. The waste to be treated with PBR/SDP is low-level by definition, so the level of radiological contamination in each drum will be well below the threshold of 200 grams of plutonium or uranium-235 at which criticality could become a concern. (Tritium and cesium do not pose a criticality concern at any concentration.) The final resolution of criticality issues should be confirmed during the detailed design process. Analysis of radiological concentrations in the waste drums will be required before treatment can begin.

\subsection{Chemical Hazards}

The wastes currently selected for treatment may contain acids, caustics, and heavy metals, including lead and mercury. They may also contain chlorinated and nonchlorinated solvents, including chloroform, methylene chloride, carbon tetrachloride, and benzene and other aromatics. (See the listing of possible hazardous constituents in Section 5.) Dedicated eyewash stations and safety showers will be placed within 
the distances required by the Occupational Safety and Health Administration (OSHA). Personnel exposure issues during waste transfer will be addressed during detailed design (see Section 3.0).

\subsection{Burn Hazards}

All hot surfaces will be insulated, as required by OSHA, to be no higher than $120^{\circ} \mathrm{F}$ on the exterior surface. The exception is the section of pipe between the PBR (R-100) and the Quench Chamber (E-110), which is uninsulated to reduce the requirement for quench water. Exterior burn protection will be provided for this section of piping.

\subsection{Fire Hazards}

A portable fire extinguishing system will be installed on each skid.

\subsection{Electrical Hazards}

All skid-mounted electrical components shall be installed in accordance with the applicable provisions of OSHA requirements contained in 29 CFR 1910, Subpart S, and the National Electrical Code to minimize personnel exposure to hazards.

\subsection{Spill Containment Concerns}

Each skid will be equipped with secondary containment for spill control in the form of a "sump" built into the bottom of each skid. The skid will have grating in the floor to allow liquids to fall through the bottom of the skid into the sump. The capacity of the sump on each skid will be equal to at least 110 percent of the total quantity of liquid in the largest vessel on that skid. For example, the feed preparation skid sump will be able to contain 193 gal, 110 percent of the 175-gal working volume of the feed tank, including all of the associated piping.

\subsection{Air Monitoring}

Continuous air monitors for organics and radioactive material will be used to alert workers of inadvertent releases. Operating personnel will be trained in the use of these monitors, or trained personnel will be provided for routine sampling and for such special sampling as may be deemed appropriate.

\subsection{HAZOP and Process Hazards Analysis}

The MTU will be designed to provide adequate protection for the health and safety of operators, collocated workers, and the public. Safety analysis of the MTU design will include two stages of review.

- A HAZOP analysis to determine risk factors and consequences related to the normal operation of the MTU, to determine causes of deviations from normal operation, identify the consequences of such deviations, and quantify the hazards so that mitigation can be done.

- A process hazards analysis (PHA) to determine the hazard classification of the MTU, quantify the materials at risk, and determine the maximum credible release scenario(s). The PHA uses the results of the HAZOP analysis, and the mitigation performed as a result of the HAZOP, as the basis for risk evaluation. 
Both of these analyses impact the MTU design, so both must be complete before the detailed MTU design can be completed.

A preliminary HAZOP analysis of the PBR portion of the MTU was performed during the preparation of this DDR. A report on the results of that analysis is presented in Appendix C. (The preliminary HAZOP did not cover the SDP unit, which is outside the scope of this DDR. A separate HAZOP must be performed on the SDP design.) The preliminary PBR HAZOP identified 148 "action items," design and/or procedural modifications that would mitigate potential hazard scenarios. Eighty-eight of the action items identified during the preliminary PBR HAZOP are addressed in this DDR. The remainder cannot be resolved at this stage, and must be addressed during the detailed design or during preparation of the standard operating procedures. Appendix $C$ also lists all HAZOP action items that remain to be addressed.

The PHA will be performed prior to completion of the detailed design, and the final PHA report will be issued at the same time as the detailed design package. 
This page intentionally blank 


\subsection{References}

American Institute of Steel Construction, Inc., 1989. Manual of Steel Construction-Allowable Stress Design, "Specifications for Structural Steel Buildings, Allowable Stress Design and Plastic Design," Chicago, Illinois.

American National Standards Institute: ANSI/ASME Standard B46.1, 1995. "Surface Texture."

ANSI/ASME Standard B31.3, 1993. "Chemical Plant and Petroleum Refinery Piping."

American Society of Mechanical Engineers, 1992. ASME Boiler and Pressure Vessel Code, Section VIII, "Rules for Construction of Pressure Vessels," New York, Nèw York.

Gullett, B.K., P.M. Lemieux, and J.E. Dunn, 1994. "The Role of Combustion and Sorbent Parameters in Prevention of Polychlorinated Dibenzo-p-Dioxin and Polychlorinated Dibenzofuran Formation During Waste Combustion," Environmental Science Technology, Volume 28(1):107-118.

Los Alamos National Laboratory, 1996a. Personal communication between John Coogan, Los Alamos National Laboratory, Los Alamos, New Mexico, and Randolph B. Richardson, Principal Engineer, Rust Geotech, Grand Junction, Colorado, January 4.

1996b. Personal communication between Tom McLaughlin, Criticality Specialist, Los Alamos National Laboratory, Los Alamos, New Mexico, and Randolph B. Richardson, Principal Engineer, Rust Geotech, Grand Junction, Colorado, March 1.

1994. A Two-Stage, Packed Bed/Silent Discharge Plasma Waste Treatment Test Bed, prepared by the Alternative Combustion Laboratory for the Los Alamos National Laboratory, Los Alamos, New Mexico.

\section{U.S. Code of Federal Regulations:}

Title 29, "Labor."

Title 40, "Protection of Environment."

Title 49, "Transportation."

Rust Geotech, 1994. Value Engineering Workshop for Packed-Bed Reactor and Silent-Discharge Plasma Treatment Technologies, unpublished letter of October 14, 1994, to Jolene Stelmach, U.S. Department of Energy Grand Junction Projects Office from John M. Waage, Rust Geotech, Grand Junction, Colorado.

U.S. Department of Energy, 1995. Needs Assessment: Use of Tritium Capture Technology to Mitigate Air Release of Tritium From Treatment Skids Deployed for the Albuquerque Operations Office Mixed-Waste Treatment Program, prepared by J.T. Gill, EG\&G Mound Applied Technologies, for the U.S. Department of Energy Miamisburg Area Office, Miamisburg, OH, November 2.

1994. AL Mixed-Waste Treatment Plan, prepared by the Treatment Selection Team for the Waste Management Division, U.S. Department of Energy, Albuquerque Operations Office, Albuquerque, New Mexico, March. 
This page intentionally blank 


\section{Appendix A}

\section{PBR/SDP}

Process and Instrumentation Diagrams and Electrical Distribution 
This page intentionally blank 




Figure A-1. PBR/SDP P\&ID Drawin! 
TYPICAL INSTRUMENT LINE IDENTIFICATION

\section{DIRECT CONNECTION TO PROCESS}

PNEUMATC SYMBOL

ELECTRIC SGNAL

CAPILLARY (FUUD FULE)

SOFTWARE LINK OR DATA LINK

\begin{tabular}{|c|c|}
\hline \multirow{2}{*}{$\begin{array}{l}\text { SMIBO DENOTES SIGNAL TRANSFER } \\
\text { THPE (OISTRIBUTED CONTROL SYSTEM) }\end{array}$} & IRANSDUCER DESICNATIONS \\
\hline & \multirow{2}{*}{$\begin{array}{l}\text { I/P - CURRENT-TO-PNEUMATC } \\
\text { P/ - PNEUMATC-TO-CURRENT }\end{array}$} \\
\hline \multirow{3}{*}{$\begin{array}{l}\text { SMIBOL DENOTES SIGNAL TRANSFER } \\
\text { TPEE (PROGRAMABLE LOGC } \\
\text { CONTROLIER) }\end{array}$} & \\
\hline & \multirow{3}{*}{$\begin{array}{l}\text { E/P - VOLTAGE-TO-PNEUMATIC } \\
\text { E/ - VOLTAGE-TO-CURRENT } \\
\text { I/A - CURRENT-TO-CURRENT }\end{array}$} \\
\hline & \\
\hline ANALOG INPUT & \\
\hline \multicolumn{2}{|l|}{ ANALOG OUTPUT } \\
\hline DIGTAL INPUT & 4-20MA (1/P PNEUMATC \\
\hline DIGTAL OUTPUT & OUTPUT \\
\hline PULSE INPUT & I/P TRANSOUCER \\
\hline PULSE OUIPUT & - TYPES OF POWER SUPPLY \\
\hline RTD INPUT & AS - AIR SUPPLY \\
\hline \multirow[t]{3}{*}{ THERMOCOUPLE INPUT } & IA - INSTRUMENT AIR \\
\hline & - ELECTRIC SUPPLY \\
\hline & GS - GAS SUPPLY \\
\hline \multirow{4}{*}{$\begin{array}{l}\text {-2 LETTER OESGGATIONS APPLY TO } \\
\text { PROGRAMUABLE LOGC CONTROLLERS. } \\
\text { I.E. }\end{array}$} & HS - HMDRAUUC SUPPLY \\
\hline & NS - NITROGEN SUPPLY \\
\hline & SS - STEAM SUPPLY \\
\hline & WS - WATER SUPPLY \\
\hline
\end{tabular}

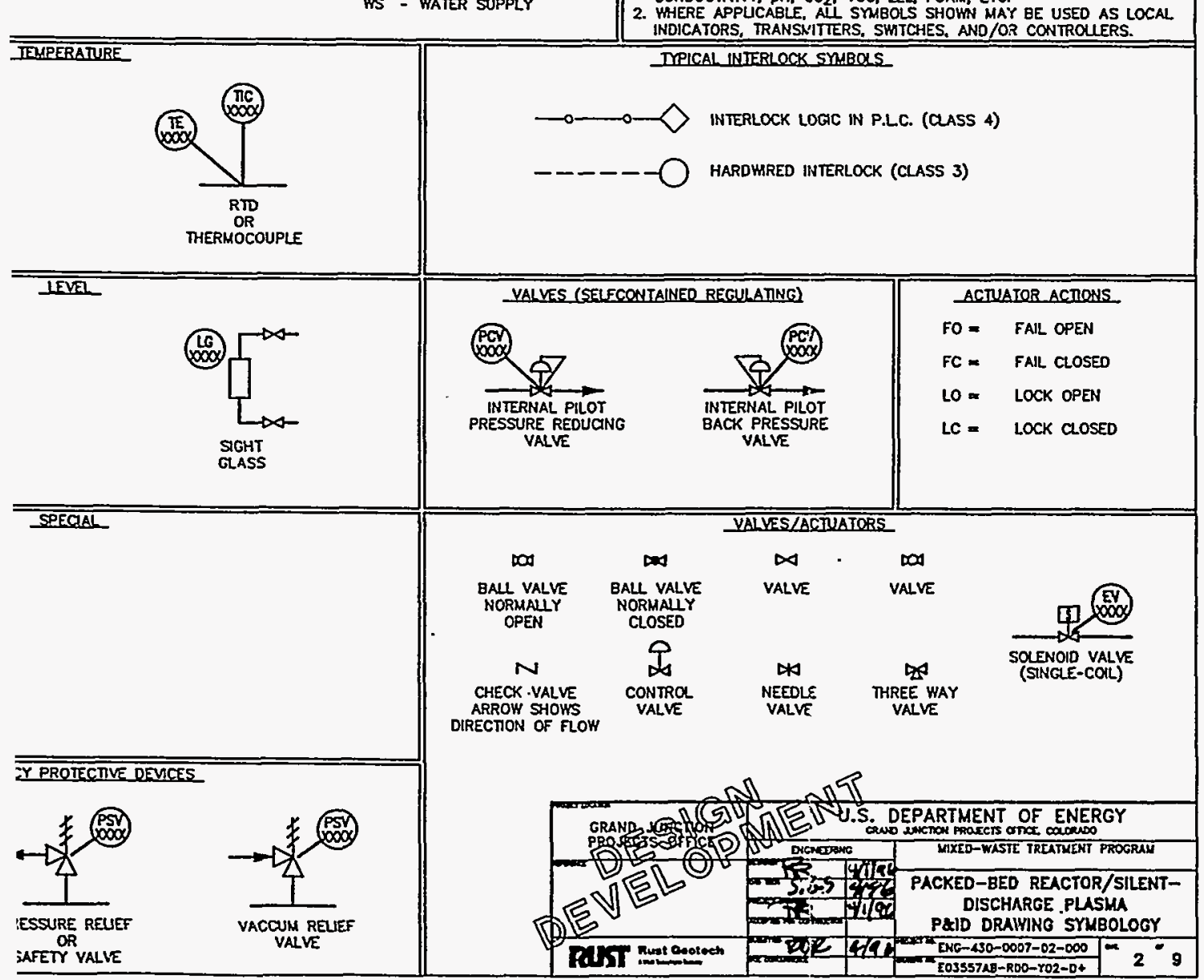

3ymbology (Drawing E03557) $A A-B B-C C C-D D$

AA - PIPE SIZE

CCC = ASSOCIATED EOURPMENT NO.

OD = UNIOUE LINE NO.

BB PIPE SPECIFICATION NO.

$26 A=$ NICKEL ALOY PIPE

$2.6 \mathrm{~B}=316$ SS PIPE

$2.6 \mathrm{C}=304$ SS TUBING
$2.60=$ COPPER TUBING

VALVE IDENTIFICATION:

1. TPE OF VALYE

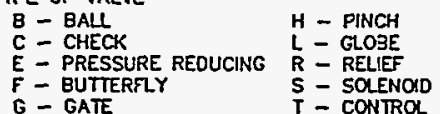

2. MATERIAL OF CONSTRUCTION OF BODY

0 - BRONZE 5 - ZINC

1 - CAST IRON/DUCTLE IRON 7 - STAINLESS STEEL

2 - ALUMINUMM

3. PRESSURE RATNG

$$
\begin{aligned}
& 1=150 \\
& 2=300 \\
& 3=300
\end{aligned}
$$

4. END CONNECTON

A - FLANGED D - THREADED

B - MECHAIIICAL MOINT F - HAFER
C - SOCKET WELD

5. VARIATION IN STME, IRIM, ACCESSORIES, ETC.

6. VALVE NUMBER: SEOUENTAL NUMBER FOR THE VALVE GROUP EXAMPLE:

G 4 (C.1) A $A-001$

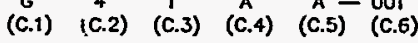

\section{NOTES:}

NOTES:

CONOUCTVTY, $\mathrm{OH}, \mathrm{CO}_{2}$, VOC, LEL, FOAM, ETC

DE USED AS LOCAL SWTCHES, AND/OR CONTROLLRS.

\section{TMICAL INEERLOCK SMBOS}

PROCESS FLOW STREAM IDENTIFIERS 


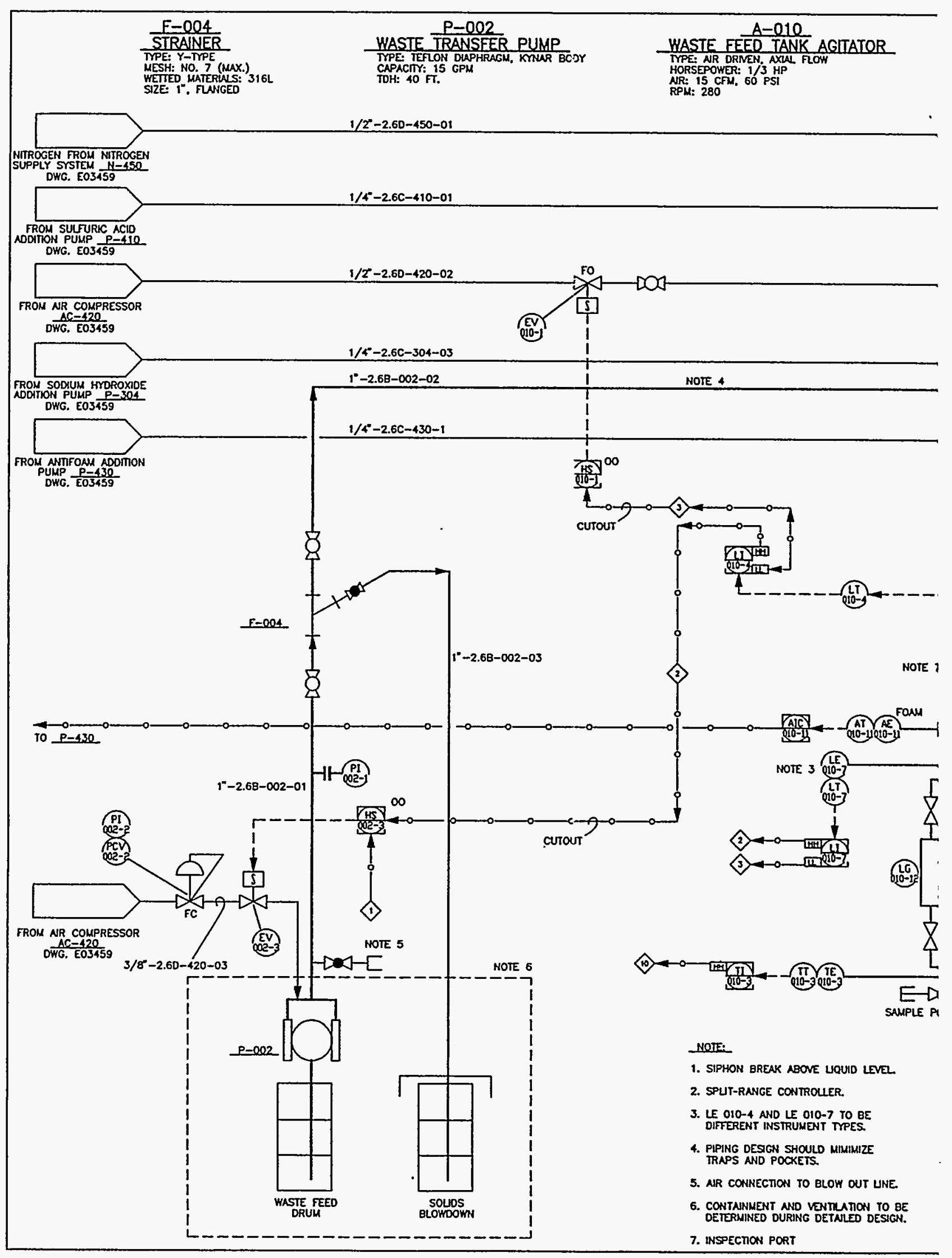

Figure A-2. PBR/SDP P\&ID Fe€ 


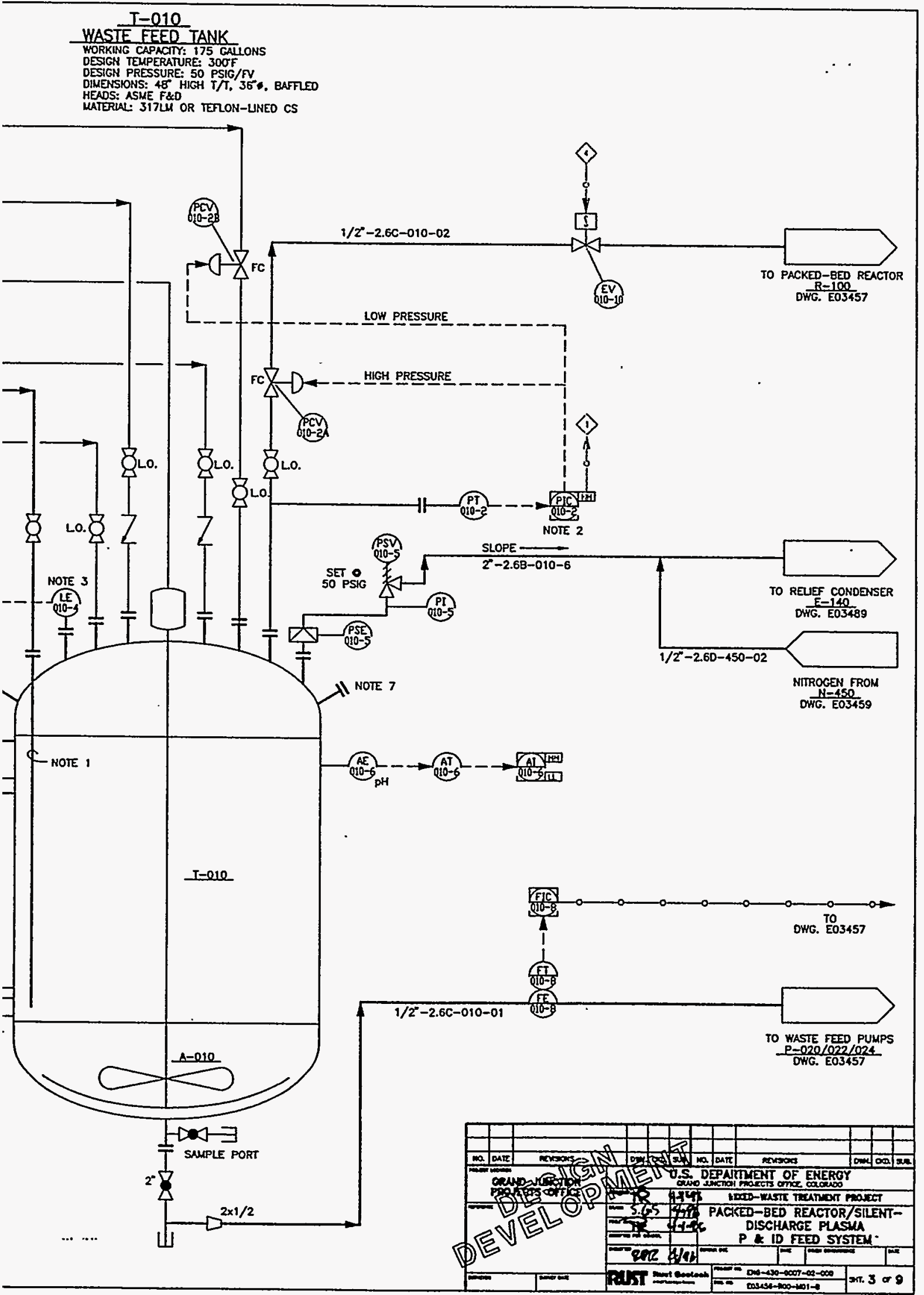




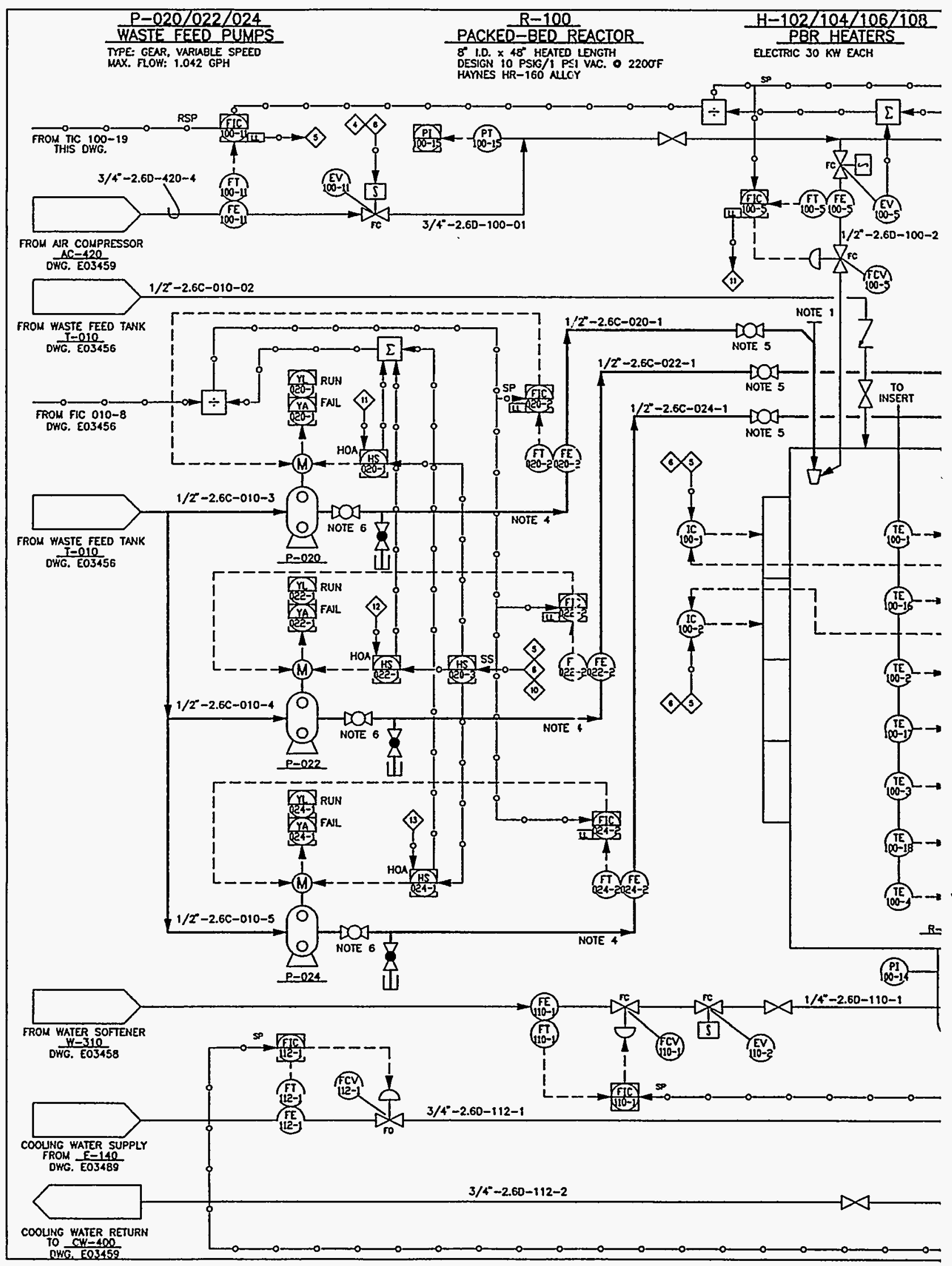

Figure A-3. PBR/SDP P\&ID Packe 


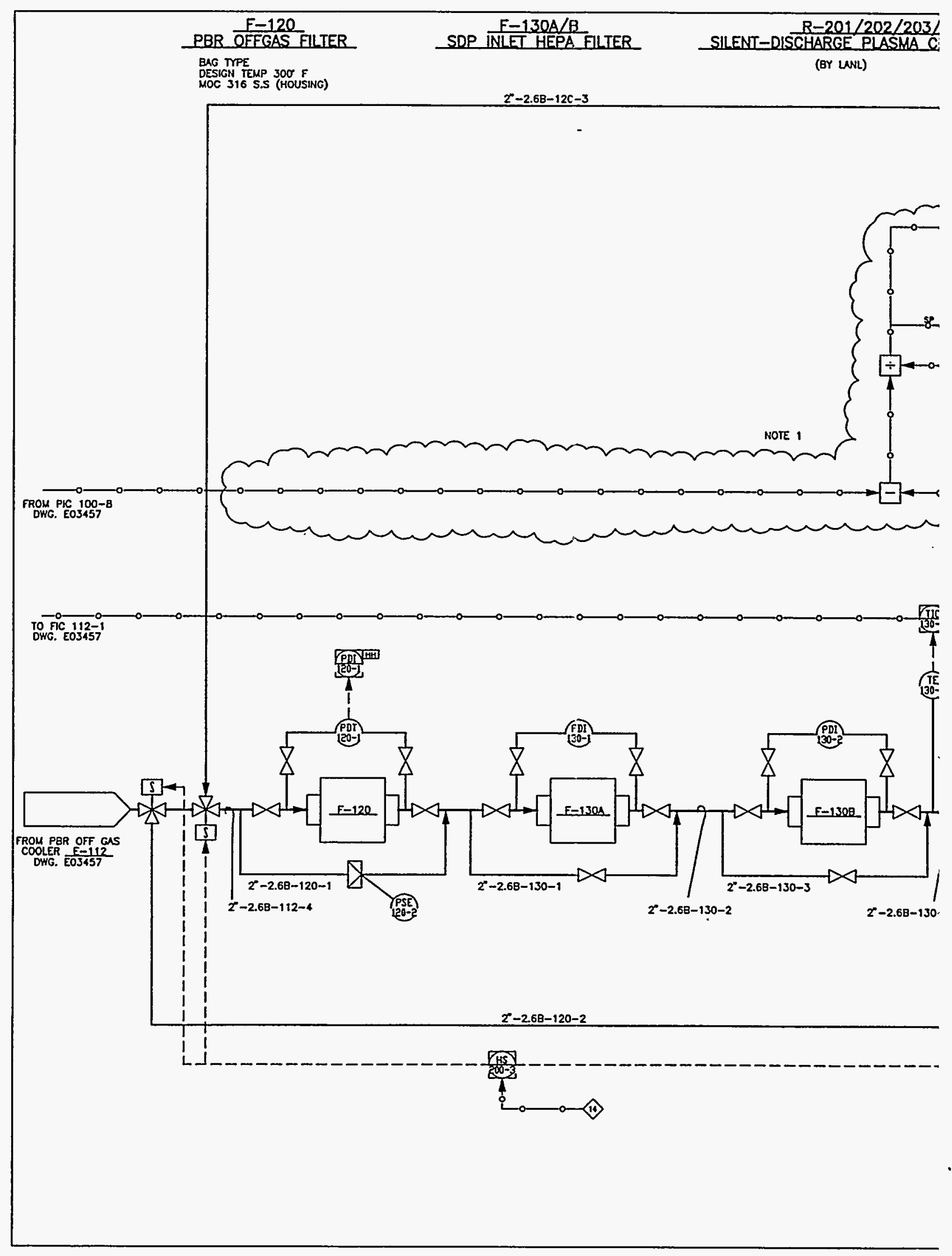

Figure A-4. PBR/SDP P\&ID Silent-Di 
4 BANKS 1-4

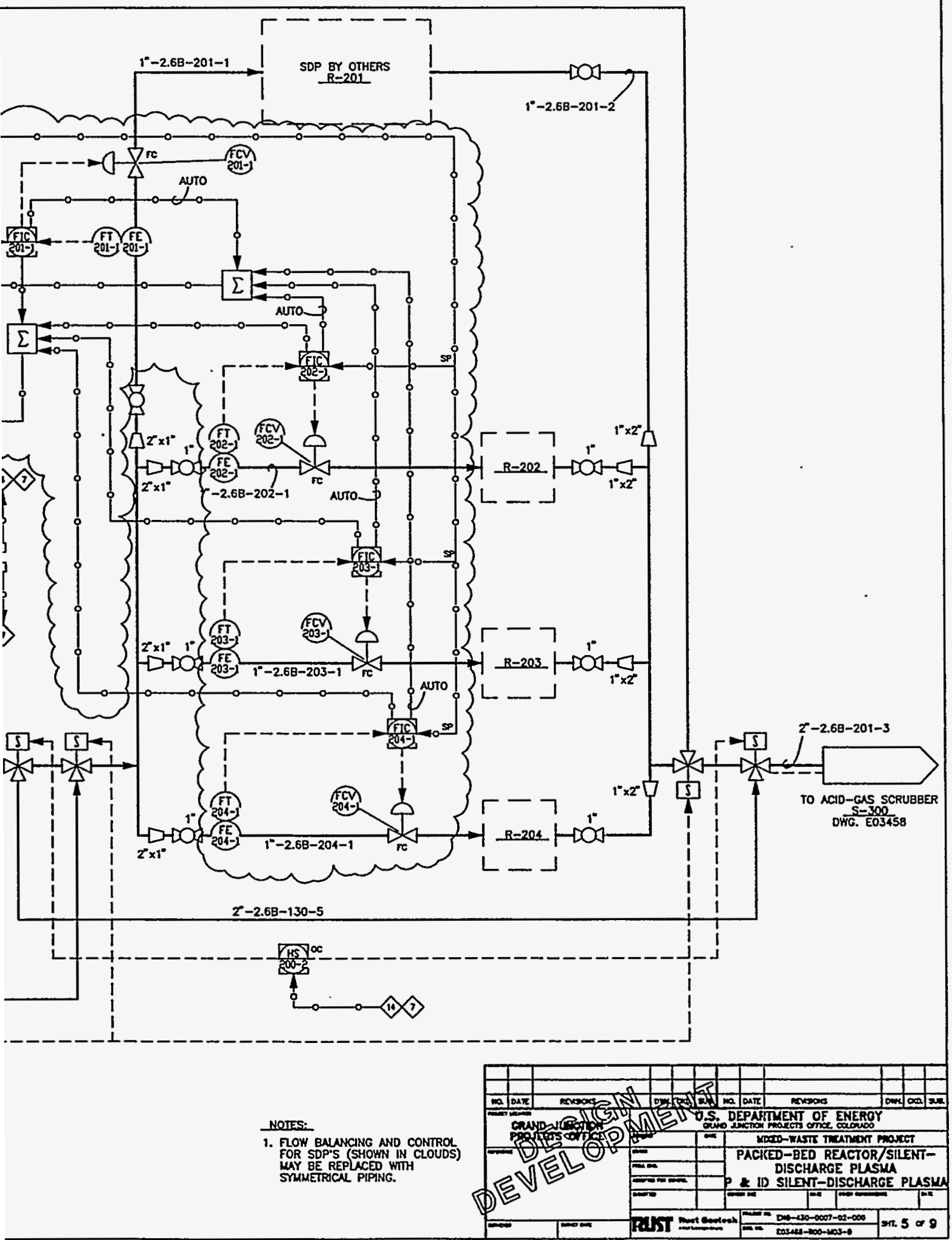




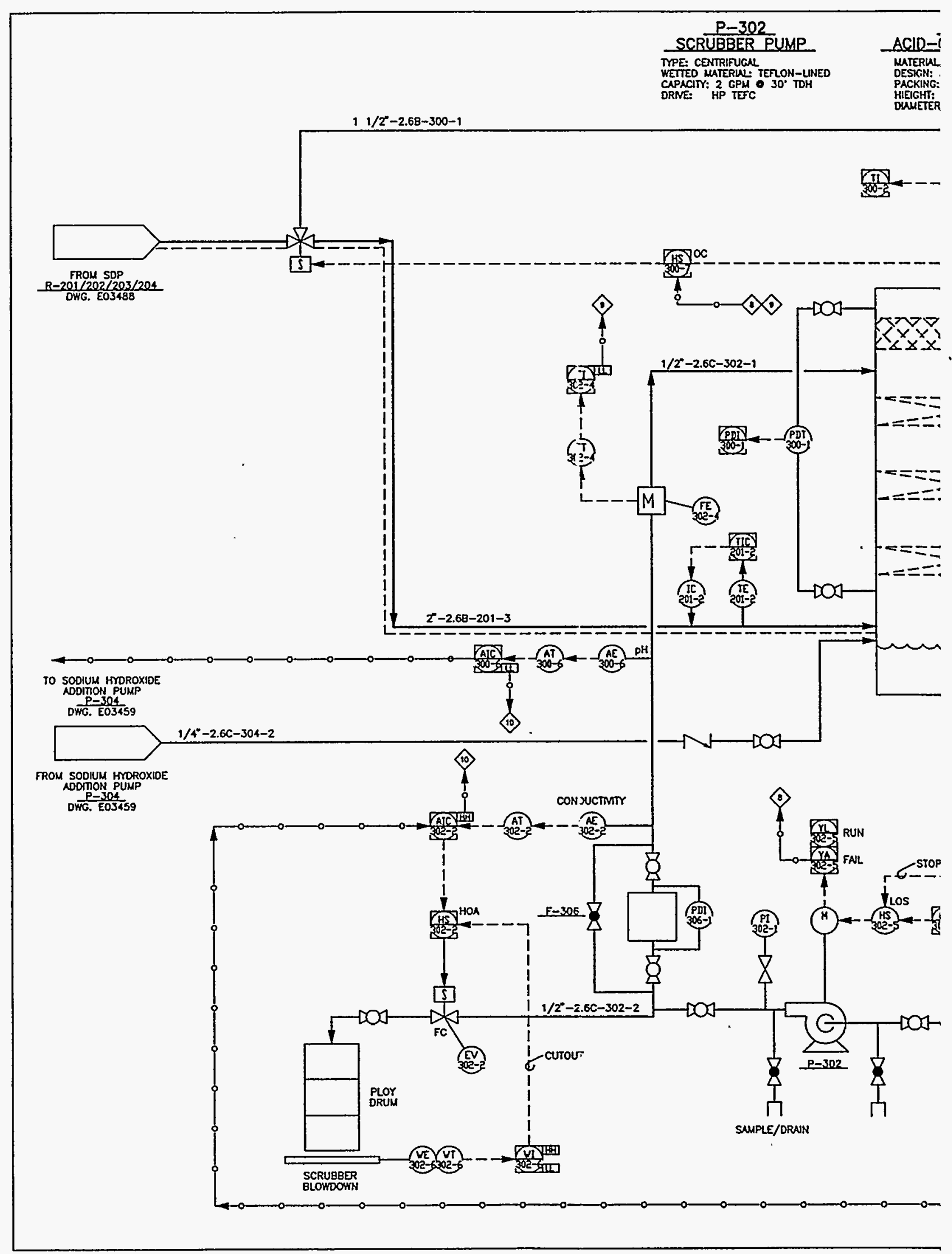

Figure A-5. PBR/SDP P\&ID Acid-C 
$-300$

¿ SCRUBBER.

sic 0 500 $F$

H RDOPAC TERLON OR FRP

WX.
1.D.

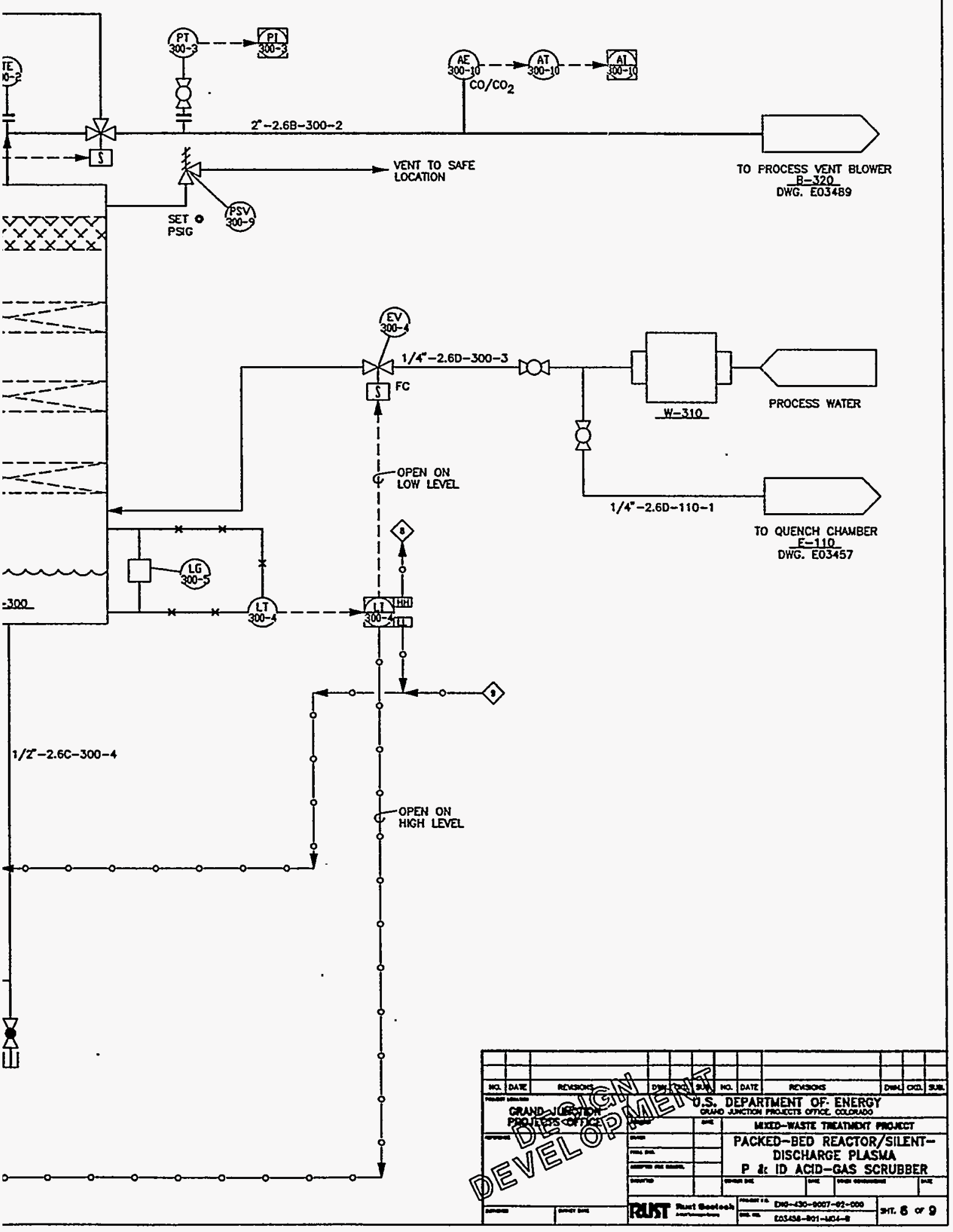




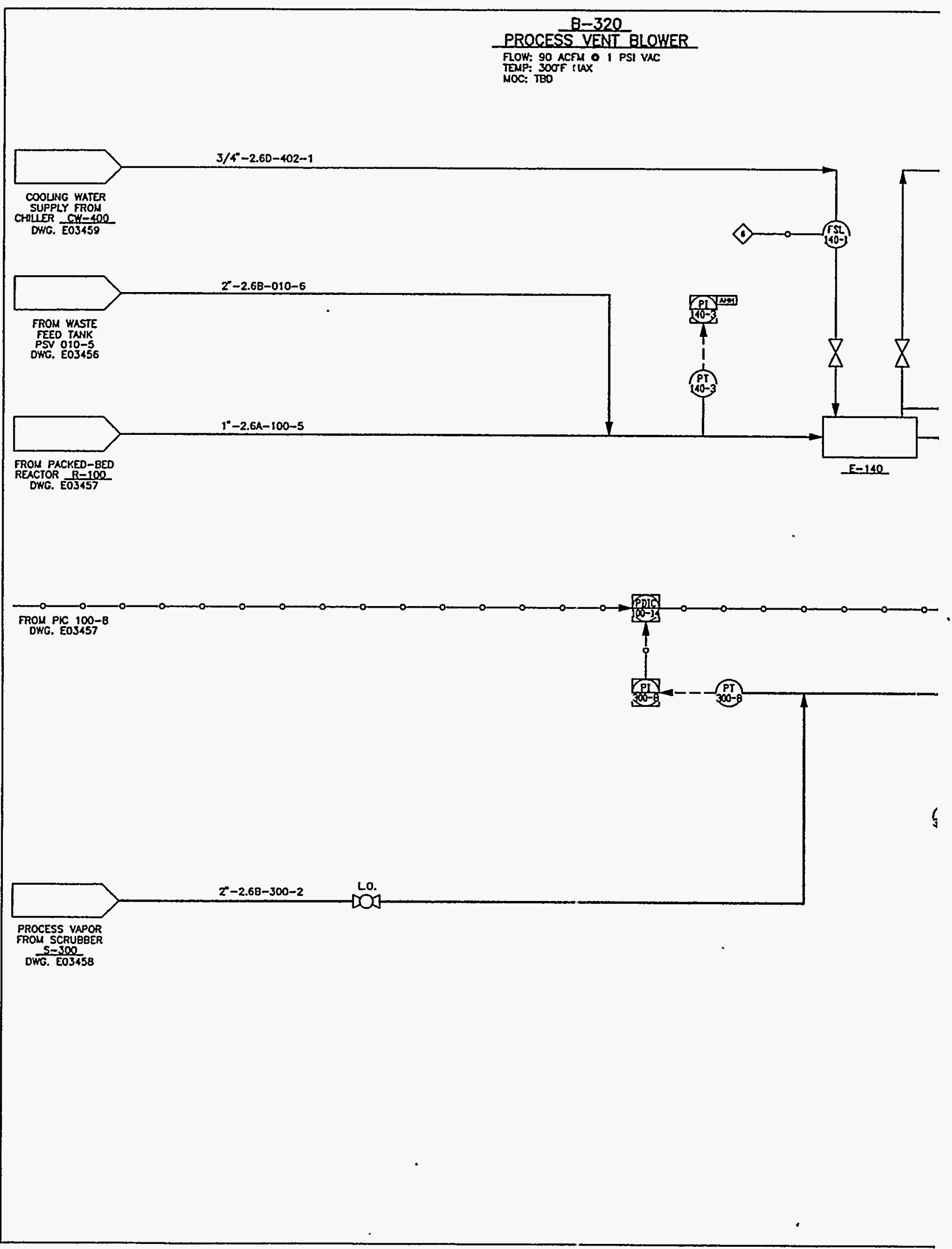

Figure A-6. PBR/SDP P\&ID Off-Gas f 


\begin{tabular}{|c|c|c|}
\hline $\begin{array}{l}\text { RELIEF CONDENSER } \\
\frac{E-140}{\text { DUM: TRD }} \\
\text { SHEI. TBD } \\
\text { THEES: TBD } \\
\text { MOC: TBD }\end{array}$ & $\begin{array}{l}\text { RELUEF DEMISIER } \\
\frac{T-142}{\text { SIEE: RRO }} \\
\text { MOC: IBO }\end{array}$ & 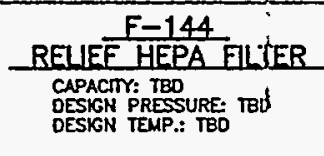 \\
\hline
\end{tabular}

$3 / 4^{-}-2.60-112-1$
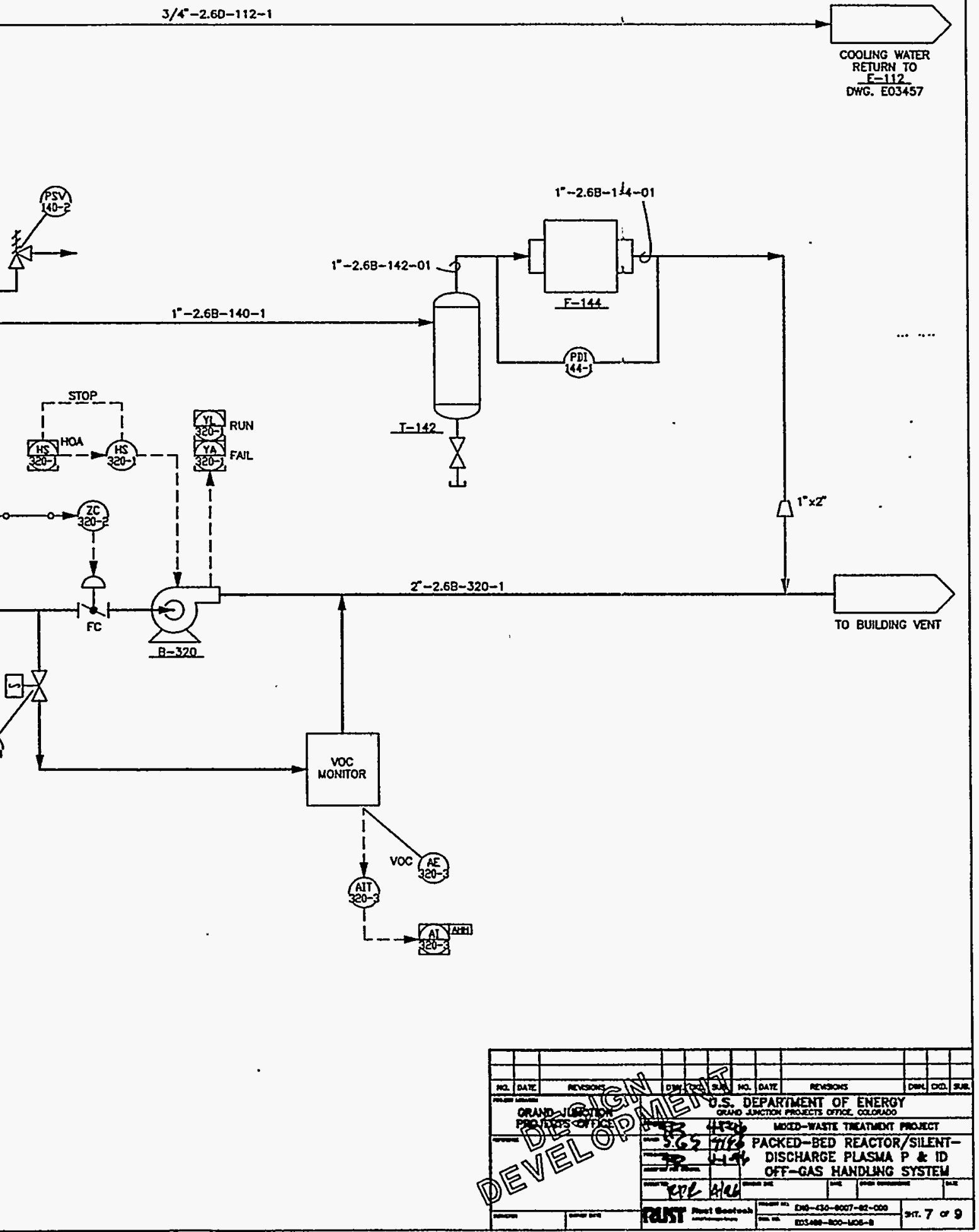

ndling System (Drawing E03489)

Packed-Bed Reactor/Silent-Discharge Plasma Design Data Report 


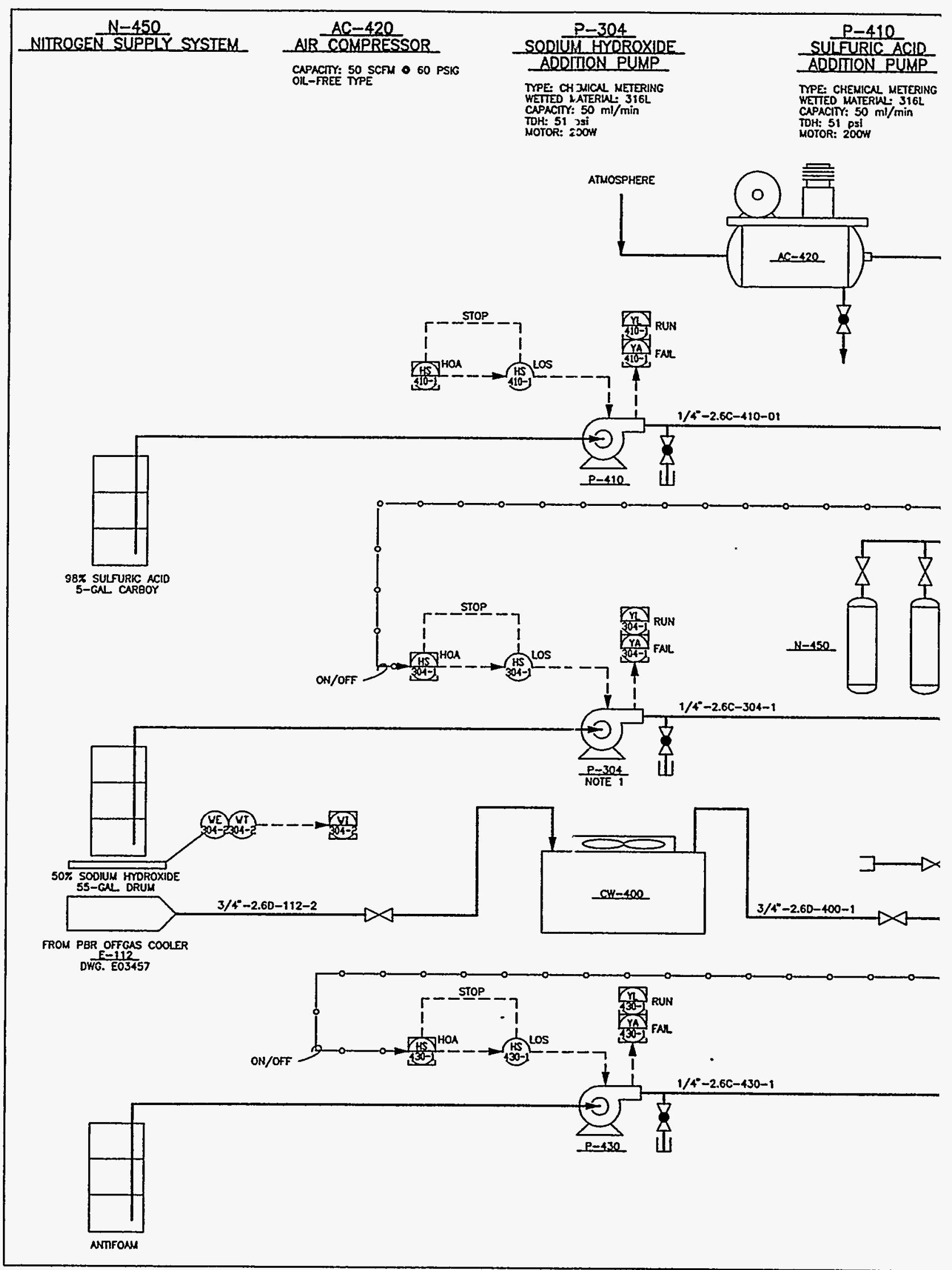

Figure A-7. PBR/SDP P\&ID Utility/Cl 


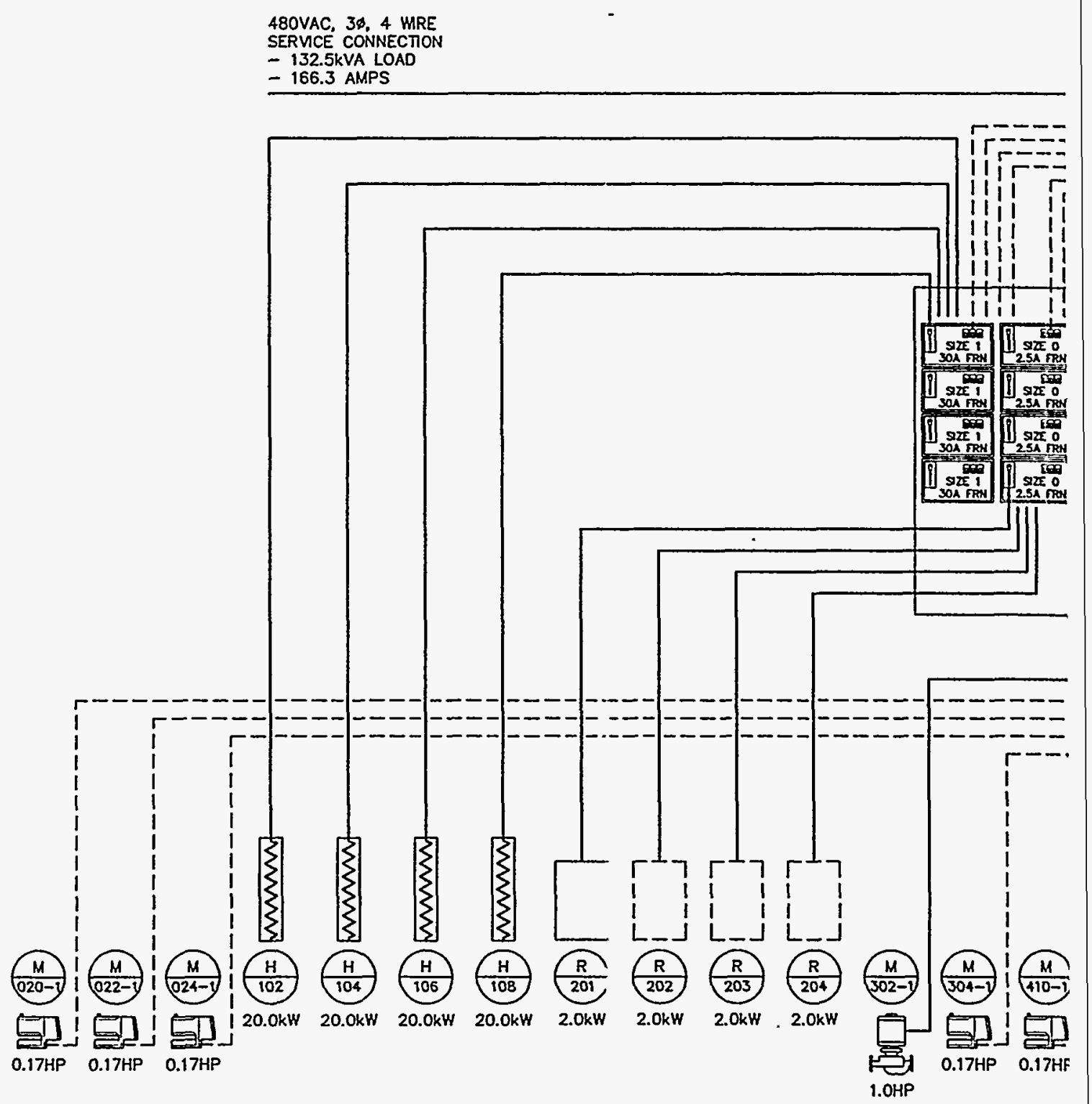

NOTES

1. ALL MOTORS SHALL BE RATED AT 1.15 SERVCE FACTOR OR CONTINUOUS DUTY AT 7,500 FEET ELEVATION.

2. THE ENTIRE INSTALLATION SHALL BE IN COMPUANCE MTH CLASS 1. DIVSION 2, REQUIREMENTS AS DEFINED IN NFPA 70, ARTICLE 501 . 


\section{Appendix B}

\section{PBR/SDP Technology}

Development Reports 
This page intentionally blank 


\section{PBR/SDP Technology Development Reports}

Eliasson, Baldur, and Ulrich Kogelschatz, 1991. "Nonequilibrium Volume Plasma Chemical Processing," IEEE Transactions on Plasma Science, Volume 19, Number 6, pp. 1063-1077, December.

Gill, J.T., 1995. Conceptual Design Product for Packed-Bed Reactor/Silent Discharge Plasma Waste Treatment Skid, prepared for EG\&G Mound Plant, Miamisburg, Ohio, March.

Gill, J.T., M.R. Cage, J.J. Coogan, R.A. Tennant, G.K. Anderson, M. Kang, R. Vargas, M.J. Brower, C.A. Schmidt, and I.A. Rosocha, 1994. "Destruction Efficiency Tests Using a Mixed Waste Surrogate, as Fed to a Packed Bed Reactor/Silent Discharge Plasma Apparatus," in Thermal Treatment of Radioactive, Hazardous Chemical, Mixed, Munitions, and Pharmaceutical Wastes, Proceedings of the 1994 International Incineration Conference, Houston, Texas, May 9-13.

Los Alamos National Laboratory, 1995. Preliminary Hazards Analysis for Alternative Combustion Laboratory $(A C L)$, prepared by the Alternative Combustion Laboratory for Los Alamos National Laboratory, Los Alamos, New Mexico, February 12.

1995. Conceptual Design Document for Packed-Bed Reactor (PBR)/ Silent Discharge Plasma (SDP) Unit for Mound Mixed Wastes: Silent Discharge Plasma Stage, prepared by the Alternative Combustion Laboratory for Los Alamos National Laboratory, Los Alamos, New Mexico, March 2.

1994. Packed-Bed Reactor/Silent Discharge Plasma Treatment System for Mixed Wastes-Report to EG\&G Mound Applied Technologies for FY 94 Tasks, prepared by the Alternative Combustion Laboratory for the Los Alamos National Laboratory, Los Alamos, New Mexico, June.

1993. Waste Delivery System Study for a Packed Bed Reactor, prepared by Andrew J. Krolnik, University of Minnesota, Twin Cities, as a U.S. Department of Energy Science and Engineering Research Semester project for Los Alamos National Laboratory, Los Alamos, New Mexico, December 9.

1993. Cold Plasma Destruction of Savannah River Off-Gas VOCs, Draft Test and Evaluation Report for TTP AL121109, Los Alamos National Laboratory, Los Alamos, New Mexico, October 29.

1993. PCB-Containing Mixed Wastes: Destruction Efficiency Tests Using a Kerosene/Dichlorobenzene Surrogate Mixture as Fed to a Packed Bed Reactor/Silent Discharge Plasma Apparatus at the Los Alamos National Laboratory, prepared for Los Alamos National Laboratory, Los Alamos, New Mexico, July 13.

1992. Draft Development and Testing of a Two-Stage Packed-Bed Reactor Silent Discharge Plasma Prototype, Final Report to Rocky Flats Plant for FY 92 Tasks Under TTP AL 121215, Los Alamos National Laboratory, Los Alamos, New Mexico, October 9.

Los Alamos National Laboratory, 1992. Treatment of Hazardous Organic Compounds in Gaseous and Combustible Liquid Waste Streams, Presentation to EG\&G/RFP, Los Alamos National Laboratory, Los Alamos, New Mexico, July 17. 
Rosocha, L.A., W.H. McCulla, G.K. Anderson, J.J. Coogan, M. Kang, R.A. Tennant, and P.J. Wantuck, 1992. "Nonthermal Plasma Alternative to the Incineration of Hazardous Organic Wastes," in Eleventh Annual International Incineration Conference, Albuquerque, New Mexico, May 11-15. 
Appendix C

\section{Resolution of PBR HAZOP}

Action Items 
This page intentionally blank 


\section{Resolution of PBR HAZOP Action Items}

This Appendix summarizes the actions identified during the preliminary packed-bed reactor (PBR) hazards and operations (HAZOP) analysis held on February 26-28, 1996. This preliminary HAZOP did not cover the silent-discharge plasma (SDP) unit, which is outside the scope of this design data report (DDR). The detailed results of the preliminary PBR HAZOP will be published separately. This Appendix documents changes made to the design as a result of the preliminary PBR HAZOP and the actions that remain to be addressed during the detailed design of the PBR/SDP mobile treatment unit (MTU) and the preparation of the operating procedures.

The HAZOP process is a highly structured analysis and review of hazards associated with the operation of a chemical facility. The process is divided into a number of small sections, or nodes, and the review is conducted one node at a time. The design intention for normal operation of each node is explained, and then a standard list of deviations from normal operation (e.g., high and/or low temperature, high and/or low pressure, high and/or low level, high and/or low/no flow) is applied to that node. Deviations that do not apply (e.g., high or low level for a line not containing any vessels) are removed from the list. Each remaining deviation is studied in terms of three factors.

1. All possible causes of the deviation (e.g., a plugged line for low/no flow). The causes are ranked according to their expected frequency, as defined in Table $\mathrm{C}-1$. (Because of the nature of the MTU and the waste streams that it treats, and the short expected lifetime of the MTU compared with a normal production facility, the standard frequency definitions have been modified to suit the program realities.)

2. The consequences, in terms of safety, environmental contamination, financial loss, and general (miscellaneous) consequences if the deviation occurs. The consequences are quantified according to the criteria given in Table $\mathrm{C}-2$.

3. Existing safeguards in the current design that tend to prevent the deviation from occurring.

The expected frequency of each deviation is combined with the consequence rating for the deviation in a "risk matrix" to generate an overall risk factor for the deviation. The risk matrix is given in Table C-3. The risk factors are then evaluated using the risk decision criteria in Table $\mathrm{C}-4$ to determine whether the design must be modified to provide additional mitigation.

Table C-1. Frequency Categories

\begin{tabular}{|c|l|}
\hline $\begin{array}{c}\text { Frequency } \\
\text { Rating }\end{array}$ & \multicolumn{1}{c|}{ Definition } \\
\hline \hline I & Likely during normal operation \\
\hline II & Once per waste stream \\
\hline III & Once per site \\
\hline IV & Once in the life of the MTU \\
\hline V & Not expected in the lifetime of the MTU \\
\hline
\end{tabular}


Table C-2. Consequence Categories

\begin{tabular}{||l|l|l|l|l||}
\hline & \multicolumn{1}{|c|}{ Safety } & Environment & \multicolumn{1}{|c|}{ Financial } & \multicolumn{1}{|c|}{ General } \\
\hline A - High & $\begin{array}{l}\text { Loss of worker } \\
\text { life or significant } \\
\text { public exposure }\end{array}$ & $\begin{array}{l}\text { Significant off- } \\
\text { site contamination. }\end{array}$ & Significant Costs & $\begin{array}{l}\text { Extended } \\
\text { production } \\
\text { shutdown }\end{array}$ \\
\hline B - Moderate & $\begin{array}{l}\text { Severe worker } \\
\text { injury with } \\
\text { disability, or } \\
\text { moderate public } \\
\text { exposure }\end{array}$ & $\begin{array}{l}\text { Significant off- } \\
\text { site contamination }\end{array}$ & Moderate Costs & $\begin{array}{l}\text { Short-term } \\
\text { production } \\
\text { shutdown }\end{array}$ \\
\hline C-Low & $\begin{array}{l}\text { Severe worker } \\
\text { injury without } \\
\text { disability, or } \\
\text { minor public } \\
\text { exposure }\end{array}$ & $\begin{array}{l}\text { Moderate off-site } \\
\text { contamination }\end{array}$ & Low Costs & $\begin{array}{l}\text { Loss of } \\
\text { production } \\
\text { efficiency } \\
\text { - }\end{array}$ \\
\hline D-Negligible & $\begin{array}{l}\text { Minor worker } \\
\text { injury, or public } \\
\text { exposure with no } \\
\text { health effects }\end{array}$ & $\begin{array}{l}\text { Negligible on-site } \\
\text { contamination }\end{array}$ & Negligible costs & $\begin{array}{l}\text { Minor production } \\
\text { delay for repair }\end{array}$ \\
\hline
\end{tabular}

Table C-3. Risk Matrix

\begin{tabular}{|c|c|c|c|c|c|}
\hline \multirow{2}{*}{$\begin{array}{c}\text { Consequence } \\
\text { Category }\end{array}$} & I & II & III & IV & V \\
\cline { 2 - 6 } & 1 & 1 & 1 & 2 & 3 \\
\hline \hline A & 1 & 1 & 2 & 3 & 4 \\
\hline B & 1 & 2 & 3 & 4 & 4 \\
\hline C & 2 & 2 & 4 & 4 & 4 \\
\hline D & 1 & & 4 & 4 & 4 \\
\hline
\end{tabular}

Table C-4. Risk Decision Criteria

\begin{tabular}{|c|l|}
\hline \hline Risk Number & \multicolumn{1}{|c|}{ Accepted Action } \\
\hline \hline 1 & Unacceptable Risk - Must be mitigated to Risk Number 3 or lower. \\
\hline 2 & $\begin{array}{l}\text { Undesirable Risk - Should be reduced to Risk Number } 3 \text { or lower with cost } \\
\text { enhancements. }\end{array}$ \\
\hline 3 & Acceptable With Control - Should evaluate cost effective enhancements. \\
\hline 4 & Acceptable As Is - No action necessary. \\
\hline
\end{tabular}


As the preliminary PBR HAZOP progressed, deviations and causes were identified, the consequences determined, and existing safeguards noted. The residual risk for each deviation was quantified as a risk number from Table $\mathrm{C}-3$, and the criteria in Table $\mathrm{C}-4$ were used to determine whether additional mitigative action will be required. Suggestions for possible additional mitigation are noted as "action items," which will be addressed after the PBR HAZOP review is complete.

Table $\mathrm{C}-5$ lists the total 148 action items identified during the preliminary PBR HAZOP. The actions are organized by Action Item Number and go as high as 152. A peculiarity in the HAZOP software used caused four items to be listed and numbered although no action item was identified and no safety consequence given; these were dropped from the list, but the remaining items were not renumbered. All of the action items were addressed and a recommendation for appropriate action was made.

1. Seventy-two items either were completed by accepting the HAZOP recommendation, or became moot when an alternative recommendation was accepted instead. The resolution has been added to the process and instrumentation diagrams (P\&IDs) and/or the text of the DDR as appropriate.

2. Sixteen items were reviewed with a recommendation that no action be taken. These included six items for which the hazard rating did not justify the expense of the proposed change (this applies only to items with a hazard rating of 3 or 4).

3. Forty-four items will be addressed during the detailed design. This includes 19 items relating to drum unloading, feed preparation, and waste transfer operations, which were major areas of concern during HAZOP. The DDR suggests that the detailed design may consider use of a glovebox similar to the feed preparation glovebox being incorporated into the design of the VAC*TRAX thermal desorption MTU.

4. Sixteen items will be addressed when the standard operating procedures (SOPs) are prepared.

Table $\mathrm{C}-5$ is organized with the 72 action items completed with an action taken listed first (this is why the list begins with item number 13), followed by the 16 items for which no action was taken, the 44 items that will be addressed during detailed design, and finally the 16 items that will be addressed when the SOPs are prepared. The following information is given in the action item list.

Item Number: Sequential, 1 through 152 (Numbers 38, 71, 123, and 132 were dropped).

Node: $\quad$ The description of the node (e.g., Waste Drum Feed Line) is given first, followed by the node number and deviation number in parentheses (e.g.. Node 1.6 is Node 1 , Deviation 6); a complete listing of all nodes will be given in the complete HAZOP report.

Deviation: The description of the deviation.

Risk Level: The quantified risk level, from the risk matrix in Table C-3, as determined by the HAZOP analysis for each of the four categories (safety, environmental, financial, or general) in which a risk was identified for the specific deviation.

Action Item: A description of the recommended action from the HAZOP analysis.

Resolution: The action taken to incorporate the HAZOP recommendation into the design. 
The information in Table $\mathrm{C}-5$ does not include the deviation causes identified during the HAZOP, or the expected frequency; this information will be available in the detailed HAZOP report. The risk level is given, along with the category(ies) to which it applies. For example, for the first item in Table C-5, Number 13:

The Node and Deviation was 1.6, high concentration of contaminants in the transfer line from the Waste Feed Drum to the Waste Feed Tank. The risk level was 3 for Safety, for which mitigation is recommended if cost effective. The recommended mitigation action was to avoid traps and pockets in the piping, which is simple and virtually cost-free to implement, so the recommendation was accepted and a note to avoid traps and pockets in that line was added to the P\&ID (Note 4 on drawing E03456). 


\section{Table C-5. Resolution of PBR HAZOP Action ltems}

\section{Complete Items - Action Taken or Moot}

Item Number: 13

Node: $\quad$ Waste Drum Feed Line (1.6)

Deviation: High concentration of contaminants

Risk Level: 3-Safety

Action Item: Piping design should minimize traps and low points.

Resolution: Added note to this effect to the P\&ID.

Item Number: No. 17

Node: $\quad$ Waste Drum Feed Line (1.8)

Deviation: Shutdown

Risk Level: 4-Safety, Environmental, General

Action Item: Consider blowing out feed line

Resolution: Added air connection and Note 5 to P\&ID for blowing out line.

Item Number: 22

Node: $\quad$ Sulfuric Acid Supply (2.5)

Deviation: Shutdown

Risk Level: $\quad 4-$ General

Action Item: Consider providing a means to flush out the line.

Resolution: Block and drain valves added to P\&ID. Simplest method to flush line is to disconnect the acid drum and hook up water in its place.

Item Number: 24

Node: $\quad$ Waste Feed Tank (4.1)

Deviation: High level

Risk Level: 2-Environmental

Action Item: Consider making the two level probes of different types.

Resolution: Note to this effect added to P\&ID.

Item Number: 25

Node: $\quad$ Waste Feed Tank (4.1)

Deviation: High level

Risk Level: 2-Environmental

Action Item: Consider adding a sight glass.

Resolution: Added LG 010-12.

Item Number: 26

Node: Waste Feed Tank (4.2)

Deviation: Low level

Risk Level: $\quad 3-$ General

Action Item: Consider impeller design to work/wipe bottom of tank.

Resolution: Revised representation on P\&ID and added requirement for wiping bottom of tank to description in DDR. 
Table C-5 (continued). Resolution of PBR HAZOP Action Items

\section{Complete Items - Action Taken or Moot (continued)}

Item Number: 28

Node: Waste Feed Tank (4.2)

Deviation: Low level

Risk Level: $\quad 3$-General

Action Item: Consider continuous circulation of liquids in tank.

Resolution: Revised agitator design (see No. 26) will handle this.

Item Number: 29

Node: $\quad$ Waste Feed Tank (4.9)

Deviation: Foam

Risk Level: $\quad 1$-General

Action Item: Consider adding antifoam.

Resolution: Added P-430 and antifoam carboy and piping.

Item Number: 30

Node: $\quad$ Waste Feed Tank (4.9)

Deviation: Foam

Risk Level: $\quad 1$-General

Action Item: Consider adding a foam sensor

Resolution: Added AIC 010-11.

Item Number: 36

Node: $\quad$ Waste Feed Tank (4.3)

Deviation: High temperature

Risk Level: 3-Safety

Action Item: Consider interlocking TI 010-3 with all feeds.

Resolution: $\quad$ Added to Interlock 10.

Item Number: 37

Node: $\quad$ Waste Feed Tank (4.3)

Deviation: High temperature

Risk Level: 3 -Safety

Action Item: Consider inerting the tank.

Resolution: PIC 010-2 and Nitrogen Addition System N-450 added.

Item Number: 39

Node: Waste Feed Tank (4.5)

Deviation: Low pressure

Risk Level: $\quad$ 2-General

Action Item: Consider adding inerts.

Resolution: Done; see \#37. 
Table C-5 (continued). Resolution of PBR HAZOP Action Items

Complete Items - Action Taken or Moot (continued)

Item Number: 40

Node: $\quad$ Waste Feed Tank (4.8)

Deviation: Shutdown

Risk Level: $\quad 3$-Financial

Action Item: Consider adding inspection ports on top of tank.

Resolution: Added ports to P\&ID.

Item Number: 41

Node: $\quad$ Waste Feed Tank (4.8)

Deviation: Shutdown

Risk Level: $\quad 3$-Financial

Action Item: Add flush connections at the bottom of tank.

Resolution: Added to P\&ID

Item Number: 42

Node: $\quad$ Waste Feed Tank (4.11)

Deviation: Inability to sample tank.

Risk Level: 3-Financial

Action Item: Consider adding sample ports to tank.

Resolution: Sample ports added.

Item Number: 43

Node: $\quad$ Waste Feed Tank Vent (5.2)

Deviation: Low/no flow

Risk Level: $\quad 4$-General

Action Item: Reroute vent line to top of reactor.

Resolution: Vent line moved.

Item Number: 44

Node: Waste Feed Tank Vent (5.2)

Deviation: Low/no flow

Risk Level: $\quad 4$-General

Action Item: Revisit pressure control scheme.

Resolution: Added PIC 010-2.

Item Number: 45

Node: $\quad$ Waste Feed Tank Vent (5.3)

Deviation: Reverse flow

Risk Level: $\quad 2-$ Safety

Action Item: Review inerting tank.

Resolution: Done; see \#37. 
Table C-5 (continued). Resolution of PBR HAZOP Action Items

\section{Complete Items - Action Taken or Moot (continued)}

Item Number: 46

Node: $\quad$ Waste Feed to PBR (6.1)

Deviation: High flow

Risk Level: $\quad 4$-Safety

Action Item: Consider tying bed temperature to air flow controller.

Resolution: Added RSP link from TIC 100-19 to FIC 100-5/6/7.

Item Number: 47

Node: $\quad$ Waste Feed to PBR (6.2)

Deviation: Low/no flow

Risk Level: 4 -Safety

Action Item: Consider pressure gauge on each line.

Resolution: Moot since each line will have flow measurement (see \#49).

Item Number: 48

Node: $\quad$ Waste Feed to PBR (6.2)

Deviation: Low/no flow

Risk Level: $\quad 4$-Safety

Action Item: Consider supplying same power to each pump (manual operation).

Resolution: Moot since each line will have flow measurement (see \#49).

Item Number: 49

Node: $\quad$ Waste Feed to PBR (6.2)

Deviation: Low/no flow

Risk Level: 4-Safety

Action Item: Consider flow measurement for each nozzle feed line.

Resolution: Added FI 020-3 and FI 022/024-2 on individual lines.

Item Number: 52

Node: $\quad$ Waste Feed to PBR (6.4)

Deviation: High pressure

Risk Level: 2-Safety

Action Item: Consider using larger line.

Resolution: Increased line size to $1 / 2 "$.

Item Number: 53

Node: $\quad$ Waste Feed to PBR (6.4)

Deviation: High pressure

Risk Level: 2-Safety

Action Item: Consider facilitating line clean-up.

Resolution: Added block and drain valves for each feed line. 
Table C-5 (continued). Resolution of PBR HAZOP Action Items

Complete Items - Action Taken or Moot (continued)

Item Number: 54

Node: $\quad$ Waste Feed to PBR (6.4)

Deviation: High pressure

Risk Level: 2-Safety

Action Item: Piping design should minimize or eliminate pockets.

Resolution: Note to this effect added to P\&ID.

Item Number: 57

Node: $\quad$ Waste Feed to PBR (6.7)

Deviation: Shutdown

Risk Level: 4-Safety

Action Item: Piping design should minimize elbows and traps.

Resolution: $\quad$ Note 4 added to P\&ID.

Item Number: 59

Node: $\quad$ Air Feed to PBR (7.1)

Deviation: High flow

Risk Level: $\quad 2-$-General

Action Item: Consider flow controls for individual nozzles.

Resolution: Added individual controllers FIC 100-5/6/7 for air flow.

Item Number: 60

Node: $\quad$ Air Feed to PBR (7.1)

Deviation: High flow

Risk Level: $\quad 2-$ General

Action Item: Consider limiting the capacity of the air compressor.

Resolution: Moot; see \#59.

Item Number: 61

Node: $\quad$ Air Feed to PBR (7.3)

Deviation: Misdirected flow

Risk Level: $\quad 3-$ General

Action Item: Software link to prevent waste flow to a nozzle that has no air flow.

Resolution: Added interlocks 11-13 to stop waste feed to individual nozzles on LL air flow to that nozzle.

Item Number: 62

Node: $\quad$ Air Feed to PBR (7.4)

Deviation: Low pressure

Risk Level: $\quad$ 3-General

Action Item: Run air supply on high pressure header.

Resolution: Low pressure header eliminated so all air users are on high pressure. 
Table C-5 (continued). Resolution of PBR HAZOP Action ltems

\section{Complete Items - Action Taken or Moot (continued)}

Item Number: 63

Node: $\quad$ Air Feed to PBR (7.4)

Deviation: Low pressure

Risk Level: $\quad 3-$ General

Action Item: Minimum line size of $1 / 2$ inch.

Resolution: Line size changed to $1 / 2$ " on P\&ID.

Item Number: 64

Node: $\quad$ Air Feed to PBR (7.5)

Deviation: High concentration of contaminants

Risk Level: $\quad 1$-Safety

Action Item: Specify oil less compressor or filters and separators.

Resolution: Specified oil-free compressor on P\&ID and in description in DDR.

Item Number: 65

Node: $\quad$ Air Feed to PBR (7.5)

Deviation: High concentration of contaminants

Risk Level: $1-$ Safety

Action Item: Interlock waste tank vent with PBR temperature.

Resolution: Interlock added to close vent valve on low bed temperature (TI 100-19).

Item Number: 66

Node: $\quad$ Air Feed to PBR (7.6)

Deviation: Shutdown

Risk Level: 3-Environmental

Action Item: $\quad$ Add $\mathrm{CO}_{2}$ monitor between E-112 and SDP.

Resolution: Added $\mathrm{CO}_{2}$ monitor AI 112-5.

Item Number: 68

Node: $\quad$ Air Feed to PBR (7.5)

Deviation: High concentration of contaminants

Risk Level: 1 -Safety

Action Item: Consider installing bleed to check for oil in line.

Resolution: Moot since oil-free compressor will be used (see \#64).

Item Number: 69

Node: $\quad$ Packed Bed Reactor (8.1)

Deviation: High temperature

Risk Level: $\quad 3$-Safety

Action Item: Consider adding more thermocouples.

Resolution: Added midzone thermocouples TI 100-16/17/18. 
Table C-5 (continued). Resolution of PBR HAZOP Action ltems

Complete Items - Action Taken or Moot (continued)

Item Number: 70

Node: $\quad$ Packed Bed Reactor (8.1)

Deviation: High temperature

Risk Level: $\quad 3-$ Safety

Action Item: High temperature fuel shutoff.

Resolution: Added TI 100-19 to Interlock 11.

Item Number: 74

Node: $\quad$ Packed Bed Reactor (8.1)

Deviation: High temperature

Risk Level: 3-Safety

Action Item: Consider extending packed bed below heating zone.

Resolution: $\quad$ Added to P\&ID.

Item Number: 77

Node: $\quad$ Packed Bed Reactor (8.10)

Deviation: Shutdown

Risk Level: $\quad$ 2-Environmental

Action Item: Add $\mathrm{CO} 2$ monitor to determine when residual organics in bed have been consumed.

Resolution: Done; see item \#66.

Item Number: 79

Node: $\quad$ PBR Discharge to Quench Chamber (9.1)

Deviation: High temperature

Risk Level: $\quad 3-E n v i r o n m e n t a l$

Action Item: Consider making Node 9 an integral part of the PBR.

Resolution: Modified P\&ID and description in DDR so that "uninsulated pipe" is the bottom section of the packed bed:

Item Number: 81

Node : PBR Discharge to Quench Chamber (9.2)

Deviation: Low temperature

Risk Level: $\quad 3-E n v i r o n m e n t a l$

Action Item: Consider coupling heat exchanger directly to PBR (as per Mound experimental configuration \#3).

Resolution: Quench needed per VE session; configuration \#3 not tested on PCB surrogates so no data on the effectiveness of this arrangement in suppressing PCDD/PCDF formation exists.

Item Number: 82

Node: $\quad$ PBR Discharge to Quench Chamber (9.3)

Deviation: High concentration of contaminants

Risk Level: 2-Safety

Action Item: MOC must be appropriate for high chloride environment.

Resolution: , Moot (see item \#79) 
Table C-5 (continued). Resolution of PBR HAZOP Action Items

Complete Items - Action Taken or Moot (continued)

Item Number: 88

Node: $\quad$ PBR Offgas Cooler (12.1)

Deviation: High temperature

Risk Level: 3-Environmental

Action Item: Consider activating Interlock 7 on TIC 112-2.

Resolution: Done.

Item Number: 92

Node: $\quad$ SDP (13.2)

Deviation: High temperature

Risk Level: $\quad 4$-Financial

Action Item: Consider bypassing SDP (Interlock 7) on high inlet temperature.

Resolution: $\quad$ Added TIC 112-2 HH to Interlock 7.

Item Number: 93

Node: $\quad$ SDP (13.3)

Deviation: Low temperature

Risk Level: 4-Financial

Action Item: Consider bypassing SDP (Interlock 7) on low inlet temperature.

Resolution: $\quad$ Added TIC 112-2 LL to Interlock 7.

Item Number: 103

Node: $\quad$ Waste Feed Tank Relief Line (25.1)

Deviation: Low/no flow

Risk Level: 3-Safety

Action Item: Consider nitrogen sweep on relief header

Resolution: Added line $1 / 2 "-2.6 \mathrm{D}-450-02$ for this purpose.

Item Number: 104

Node: $\quad$ Waste Feed Tank Relief Line (25.1)

Deviation: Low/no flow

Risk Level: 3-Safety

Action Item: Consider high-pressure alarm on relief header.

Resolution: Added PI 140-3 and $\mathrm{HH}$ on relief header.

Item Number: 107

Node: $\quad$ PBR Relief Line (23.2)

Deviation: Low/no flow

Risk Level: $\quad 3-$ Safety

Action Item: Add nitrogen sweep in the line.

Resolution: Done (see \#103). 
Table C-5 (continued). Resolution of PBR HAZOP Action Items

Complete Items - Action Taken or Moot (continued)

Item Number: 111

Node: $\quad$ Scrubber Inlet (15.1)

Deviation: Low/no flow

Risk Level: $\quad 4$-Safety

Action Item: Consider eliminating valves in this line.

Resolution: No block valves in line after HEPA filter moved and carbon canister deleted.

Item Number: 112

Node: $\quad$ Scrubber Inlet (15.1)

Deviation: Low/no flow

Risk Level: 4 -Safety

Action Item: Consider installing PSE on F-220 (changed to F-120) bypass.

Resolution: Bypass valve changed to PSE 120-2.

Item Number: 115

Node: $\quad$ Scrubber Inlet (15.4)

Deviation: Low temperature

Risk Level: 2-Financial

Action Item: Consider using heat tracing.

Resolution: Added heat tracing and TIC/IC 201-2.

Item Number: 118

Node: $\quad$ Acid-Gas Scrubber (17.5)

Deviation: High pressure

Risk Level: $\quad 4$-Environmental

Action Item: Consider pressure relief on S-300

Resolution: Added PSV 300-9; setpoint will have to be confirmed during detailed design.

Item Number: 121

Node: $\quad$ Acid-Gas Scrubber (17.7)

Deviation: High concentration of contaminants

Risk Level: $\quad 3-$ General

Action Item: Consider filter for removal of metal hydrides.

Resolution: Added Scrubber Filter F-306.

Item Number: 122

Node: $\quad$ Acid-Gas Scrubber (17.8)

Deviation: Startup

Risk Level: $\quad 3-$ General

Action Item: Consider heat tracing inlet lines.

Resolution: Done; see item \#115. 
Table C-5 (continued). Resolution of PBR HAZOP Action Items

\section{Complete Items - Action Taken or Moot (continued)}

Item Number: 124

Node: $\quad$ SDP (13.6)

Deviation: High concentration of contaminants

Risk Level: $\quad 2$-General

Action Item: Consider moving F-220 upstream of SDP.

Resolution: Filter moved and retagged as F-120.

Item Number: 125

Node: $\quad$ Acid-Gas Scrubber (17.7)

Deviation: High concentration of contaminants

Risk Level: $\quad 3-$ General

Action Item: Consider using softened water for makeup.

Resolution: Added scrubber water as inlet to water softener W-310.

Item Number: 127

Node: $\quad$ Acid-Gas Scrubber Pump (18.6)

Deviation: Shutdown

Risk Level: $\quad$ 3-General

Action Item: Consider drain valve for scrubber.

Resolution: $\quad$ Added drain to P\&ID.

Item Number: 128

Node: $\quad$ Acid-Gas Scrubber Pump (18.6)

Deviation: Shutdown

Risk Level: $\quad 3-$ General

Action Item: Consider block valve upstream of AE 302-2.

Resolution: Block valves added upstream and downstream of filter F-306 which is upstream of AE 302-2.

Item Number: 129

Node: $\quad \mathrm{NaOH}$ Feed to Scrubber (19.1)

Deviation: High flow

Risk Level: 4-Environmental

Action Item: Consider moving $\mathrm{pH}$ probe to circulating line if filter is installed.

Resolution: Filter has been added and probe has been moved.

Item Number: 130

Node: $\quad \mathrm{NaOH}$ Feed to Scrubber (19.2)

Deviation: Low/no flow

Risk Level: 4-Environmental, General

Action Item: Consider moving caustic addition above normal liquid level.

Resolution: Line moved on P\&ID. 
Table C-5 (continued). Resolution of PBR HAZOP Action ltems

\section{Complete Items - Action Taken or Moot (continued)}

Item Number: 132

Node: $\quad$ NaOH Feed to Scrubber (19.3)

Deviation: Reverse flow

Risk Level: 1-Environmental

Action Item: Consider moving caustic addition above normal liquid level.

Resolution: See \#130.

Item Number: 134

Node: $\quad$ NaOH Feed to Scrubber (19.7)

Deviation: Shutdown

Risk Level: 3-Safety

Action Item: Consider ways to flush lines and pump at end of run.

Resolution: Block and drain valves added to P\&ID. Simplest method to flush line is to disconnect the caustic drum and hook up water in its place.

Item Number: 135

Node: $\quad$ Process Water to Scrubber (20.3)

Deviation: High concentration of contaminants

Risk Level: 2-General

Action Item: Consider using softened water.

Resolution: Scrubber makeup water will be treated with water softener W-310.

Item Number: 136

Node: $\quad$ Scrubber Blowdown Line (21.3)

Deviation: Misdirected flow

Risk Level: 4-Environmental, General

Action Item: Consider not allowing blowdown when load cell indicates drum is full.

Resolution: Added LL in WI 302-6 for cutout of HS 302-2 to disable blowdown.

Item Number: 139

Node: $\quad$ Scrubber Blowdown Line (21.6)

Deviation: High concentration of contaminants

Risk Level: 3-Environmental

Action Item: Consider installation of HEPA upstream of scrubber.

Resolution: Added F-130A/B.

Item Number: 142

Node: $\quad$ Scrubber to Vent Heater (22.2)

Deviation: High temperature

Risk Level: $\quad 3-$ Safety

4-Environmental

Action Item: Consider eliminating carbon canister C-324.

Resolution: Carbon canister eliminated. 


\section{Table C-5 (continued). Resolution of PBR HAZOP Action Items}

\section{Complete Items - Action Taken or Moot (continued)}

Item Number: 143

Node: $\quad$ Scrubber to Vent Heater (22.4)

Deviation: Low pressure

Risk Level: $\quad 4$-General

Action Item: Confirm vacuum rating of C-324 and F-322 is higher than deadhead suction of blower.

Resolution: Moot; eliminated carbon drum and moved HEPA filter.

Item Number: 144

Node: $\quad$ Scrubber to Vent Heater (22.4)

Deviation: Low pressure

Risk Level: $\quad 4$-General

Action Item: Consider vacuum break system.

Resolution: $\quad$ Moot (see item \#143).

Item Number: 145

Node: $\quad$ Scrubber to Vent Heater (22.6)

Deviation: Maintenance/sampling

Risk Level: $\quad 2$-General

Action Item: Consider moving HEPA upstream of SDP.

Resolution: Added F-130A/B.

Item Number: 146

Node: $\quad$ Scrubber to Vent Heater (22.6)

Deviation: Maintenance/sampling

Risk Level: 2-General

Action Item: Make provisions for canister changeout without shutdown :

Resolution: Moot (see \#142).

Item Number: 147

Node: $\quad$ Relief Condenser/Demister (24.4)

Deviation: High concentration of contaminants

Risk Level: $\quad 4$-Safety

Action Item: Consider sloping piping to drain away from relief devices.

Resolution: Added notes on line slope to P\&ID.

Item Number: 151

Node: $\quad$ Caustic to Waste Feed Tank (3.5)

Deviation: Shutdown

Risk Level: $\quad 3$-Safety

Action Item: Consider providing a means to flush out the line.

Resolution: Block and drain valves added to P\&ID. Simplest method to flush line is to disconnect the caustic drum and hook up water in its place. 
Table C-5 (continued). Resolution of PBR HAZOP Action Items

\section{Complete Items - No Action Taken}

Item Number: 10

Node: $\quad$ Waste Drum Feed Line (1.2)

Deviation: Reverse flow

Risk Level: $\quad$ 2-Safety, Environmental

Action Item: Consider whether drum containment needs to hold entire volume of $T-010$.

Resolution: Not needed. The siphon break in T-010 and the block valves in the transfer line will provide adequate protection.

Item Number: 11

Node: $\quad$ Waste Drum Feed Line (1.3)

Deviation: Misdirected flow

Risk Level: $\quad 3$-Safety, Environmental

Action Item: Consider directing blowdown to waste drum when drum is not in use.

Resolution: Does not make sense. The drum will not normally be in place except when it is needed.

Item Number: 19

Node: $\quad$ Sulfuric Acid Supply (2.1)

Deviation: Low/no flow

Risk Level: $\quad 4$-General

Action Item: Consider using larger feed line

Resolution: Not desirable. Increasing the line size would increase the total inventory of acid in the system.

Item Number: 21

Node: $\quad$ Sulfuric Acid Supply (2.4)

Deviation: Loss of containment

Risk Level: $\quad 3-$ Safety

Action Item: Consider using an organic acid instead of sulfuric

Resolution: No change. Use of sulfuric will minimize secondary wastes because it can be added in more concentrated form than other acids and has higher activity. The acid addition is expected to be minimal in any case.

Item Number: 27

Node: $\quad$ Waste Feed Tank (4.2)

Deviation: Low level

Risk Level: $\quad 3$-General

Action Item: Consider high-energy mixing system

Resolution: Not desirable due to emulsification concerns.

Item Number: 56

Node: $\quad$ Waste Feed to PBR (6.7)

Deviation: Shutdown

Risk Level: $\quad 4-$ Safety

Action Item: . Consider adding solvent flush system.

Resolution: Not justified at this risk level. 


\section{Table C -5 (continued). Resolution of PBR HAZOP Action Items}

\section{Complete Items - No Action Taken (continued)}

Item Number: 58

Node: $\quad$ Waste Feed to PBR (6.7)

Deviation: Shutdown

Risk Level: $\quad 4$-Safety

Action Item: Consider using translucent tubing.

Resolution: Not justified at this risk level, possibly ineffective or counterproductive since plastic may cloud or degrade.

Item Number: 83

Node: $\quad$ Quench Chamber (11.2)

Deviation: High temperature

Risk Level: $\quad 3$-Environmental, Financial

Action Item: Consider redundant temperature measurement.

Resolution: Not justified at this risk level.

Item Number: 89

Node: $\quad$ PBR Offgas Cooler (12.2)

Deviation: Low temperature

Risk Level: $\quad 4$-Financial

Action Item: Consider heat trace on line.

Resolution: Not required. TE 112-2 will be located as close as possible to the SDP to give the most accurate control of the.SDP inlet temperature.

Item Number: 94

Node: $\quad$ SDP Bypass (13.3)

Deviation: Low temperature

Risk Level: $\quad 4$-Financial

Action Item: Consider installation of condensate trap.

Resolution: Not justified at this risk level.

Item Number: 113

Node:- $\quad$ Scrubber Inlet (15.4)

Deviation: Low temperature

Risk Level: $\quad$ 2-Financial

Action Item: Consider using plastics (at least for filter)

Resolution: Not desirable; \#115 (heat tracing) will eliminate condensation.

Item Number: 114

Node: $\quad$ Scrubber Inlet (15.4)

Deviation: Low temperature

Risk Level: 2-Financial

Action Item: Consider making line out of Hastalloy.

Resolution: Not justified; \#115 (heat tracing) will eliminate condensation. 
Table C-5 (continued). Resolution of PBR HAZOP Action Items

\section{Complete Items - No Action Taken (continued)}

Item Number: 131

Node: $\quad \mathrm{NaOH}$ Feed to Scrubber (19.2)

Deviation: Low/no flow

Risk Level: $\quad 1-$ Environmental

Action Item: Consider low flow switch in series with P-304 motor starter.

Resolution: Not required; reverse flow unlikely since $\mathrm{NaOH}$ will enter above scrubber liquid level (see \#130).

Item Number: 133

Node: $\quad \mathrm{NaOH}$ Feed to Scrubber (19.5)

Deviation: Loss of containment

Risk Level: $\quad 4$-Safety

Action Item: Consider using $20 \%$ caustic.

Resolution: Not required at this risk level (general level 4); use of $50 \%$ will minimize generation of secondary waste.

Item Number: 140

Node: $\quad$ Scrubber Blowdown Line (21.6)

Deviation: Loss of containment

Risk Level: 4-Environmental

Action Item: Consider method to determine when drum is full.

Resolution: Load cell will be adequate; filter will minimize chance of deviation in specific gravity due to solids in liquid.

Item Number: 148

Node: $\quad$ Caustic to Waste Feed Tank (3.1)

Deviation: Low/no flow

Risk Level: $\quad 3$-Safety

Action Item: Consider using larger caustic line.

Resolution: Not justified; larger line would increase volume of caustic in system and increase risk if containment is lost.

\section{Detail Design Items}

Item Number: 1

Node: $\quad$ Waste Drum Feed Line (1.1)

Deviation: Low/no flow

Risk Level: $\quad 4$-Safety, General

Action Item: Consider coarse strainer in waste drum.

Comment: This item, and the following four items, have been deferred for detail design when the unloading requirements (e.g. glovebox) will be examined. (See \#6.) 
Table C-5 (continued). Resolution of PBR HAZOP Action Items

Detail Design Items (continued)

Item Number: 2

Node: $\quad$ Waste Drum Feed Line (1.1)

Deviation: Low/no flow

Risk Level: $\quad 4-$ Safety, General

Action Item: Consider blowback system for coarse strainer.

Comment: $\quad$ See \#1.

Item Number: 3

Node: Waste Drum Feed Line (1.1)

Deviation: Low/no flow

Risk Level: 4 -Safety, General

Action Item: Define blowback for F-004.

Comment: See \#1.

Item Number: 4

Node: $\quad$ Waste Drum Feed Line (1.1)

Deviation: Low/no flow

Risk Level: $\quad 4$-Safety, General

Action Item: Consider waste feed drum mixer.

Comment: See \#1.

Item Number: 5

Node: $\quad$ Waste Drum Feed Line (1.1)

Deviation: Low/no flow

Risk Level: $\quad 4$-Safety, General

Action Item: Consider installation of F-004B.

Comment: $\quad$ See \#1.

Item Number: 6

Node: $\quad$ Waste Drum Feed Line (1.1)

Deviation: Low/no flow

Risk Level: $\quad 4$-Safety, General

Action Item: Consider whether drum unloading will be glovebox operation.

Comment: This possibility is discussed in the DDR.

Item Number: 7

Node: $\quad$ Waste Drum Feed Line (1.1)

Deviation: Low/no flow

Risk Level: $\quad$ 4-Safety, General

Action Item: Determine viscosity limit of pump.

Comment: After pump data is available. 
Table C-5 (continued). Resolution of PBR HAZOP Action Items

\section{Detail Design Items (continued)}

Item Number: 8

Node: $\quad$ Waste Drum Feed Line (1.1)

Deviation: Low/no flow

Risk Level: 4-Safety, General

Action Item: Determine maximum particle size of pump

Comment: After pump data is available.

Item Number: 12

Node: $\quad$ Waste Drum Feed Line (1.6)

Deviation: High concentration of contaminants

Risk Level: $\quad 4$-Safety, Environmental

Action Item: Consider sampling drums prior to acceptance.

Comment: $\quad$ See \#1 and \#100.

Item Number: 14

Node: $\quad$ Waste Drum Feed Line (1.6)

Deviation: High concentration of contaminants

Risk Level: 4 -Safety, Environmental

Action Item: Consider using a plastic system and a metal system for unloading.

Comment: Deferred until more information on waste is available.

Item Number: 18

Node: $\quad$ Waste Drum Feed Line (1.9)

Deviation: 'Maintenance/sampling

Risk Level: · 4-Safety, General

Action Item: Consider how sampling will be done.

Comment: $\quad$ See \#1.

Item Number: 23

Node: $\quad$ Sulfuric Acid Supply (2.6)

Deviation: Maintenance/sampling

Risk Level: $\quad 3$-Safety, General

Action Item: Evaluate servicing requirements of the pump.

Comment: $\quad$ After pump data is available.

Item Number: 31

Node: Waste Feed Tank (4.10)

Deviation: High viscósity

Risk Level: $\quad 4$-General

Action Item: Define viscosity limit

Comment: After detailed information on agitator and feed pumps is available. 
Detail Design Items (continued)

Item Number: 32

Node: $\quad$ Waste Feed Tank (4.10)

Deviation: High viscosity

Risk Level: $\quad 4$-General

Action Item: Waste Acceptance Criteria to set upper limit.

Comment: See \#31.

Item Number: 33

Node: $\quad$ Waste Feed Tank (4.10)

Deviation: High viscosity

Risk Level: 4 -General

Action Item: Consider solvent addition to waste feed tank.

Comment: See \#1; solvent addition would be part of the overall feed preparation and pretreatment process.

Item Number: 34

Node: $\quad$ Waste Feed Tank (4.10)

Deviation: High viscosity

Risk Level: $\quad 4$-General

Action Item: Make drum mixer same type as tank agitator.

Comment: Detail design to evaluate drum mixer requirements (see \#4).

Item Number: 35

Node: $\quad$ Waste Feed Tank (4.10)

Deviation: High viscosity

Risk Level: 4 -General

Action Item: Make waste transfer pump equal to the viscosity limit of the waste.

Comment: $\quad$ After feed preparation/pretreatment is resolved; see \#1.

Item Number: 50

Node: $\quad$ Waste Feed to PBR (6.2)

Deviation: Low/no flow

Risk Level: $\quad 4$-Safety

Action Item: Consider putting in a finer strainer ( $\mathrm{F}-004)$.

Comment: $\quad$ Deferred as part of feed preparation/pretreatment; see \#1.

Item Number: 51

Node: $\quad$ Waste Feed to PBR (6.4)

Deviation: High pressure

Risk Level: 2-Safety

Action Item: Pump selection - pump shutoff or internal relief pressure must be lower than line pressure.

Comment: Address during pump selection process. 


\section{Table C-5 (continued). Resolution of PBR HAZOP Action Items}

\section{Detail Design Items (continued)}

Item Number: 72

Node: $\quad$ Packed Bed Reactor (8.7)

Deviation: High pressure

Risk Level: $\quad 4$-Environmental

Action Item: Consider increasing PBR design pressure.

Comment: Preliminary calculations indicate that a maximum pressure rating of $10 \mathrm{psig}$ can be obtained with a wall thickness of $1 / 2 "$. The P\&ID and description in the DDR have been changed to show a pressure rating of $10 \mathrm{psig}$, but detailed design should obtain more information on maximum allowable stress for $\mathrm{HR}-160$ at $2200^{\circ} \mathrm{F}$ to confirm that this design rating is possible.

Item Number: 73

Node: $\quad$ Packed Bed Reactor (8.3)

Deviation: High temperature

Risk Level: $\quad 3$-Safety

Action Item: Consider adding a fan for top of reactor.

Comment: Concern is high temperature on the exterior of the reactor.

Item Number: 75

Node: $\quad$ Packed Bed Reactor (8.8)

Deviation: High concentration of contaminants

Risk Level: $\quad 3-$ Safety 4-Environmental, Financial

Action Item: Analyze waste drum contents for radionuclides.

Comment: Deferred as part of feed preparation/pretreatment (see \#1); added suggestion to DDR.

Item Number: 76

Node: $\quad$ Packed Bed Reactor (8.8)

Deviation: High concentration of contaminants

Risk Level: $\quad 3-$ Safety

4-Environmental, Financial

Action Item: Initial review by Health Physicist (HP).

Comment: $\quad$ HP will review final design package.

Item Number: 80

Node: $\quad$ PBR Discharge to Quench Chamber (9.2)

Deviation: Low temperature

Risk Level: $\quad 3$-Environmental

Action Item: Design to allow bed height adjustment during setup.

Comment: The need is mentioned in the DDR for incorporation in the final design. 
Table C-5 (continued). Resolution of PBR HAZOP Action Items

Detail Design Items (continued)

Item Number: 84

Node: $\quad$ Quench Chamber (11.5)

Deviation: High concentration of contaminants

Risk Level: $\quad 3-F i n a n c i a l$, General 4-Safety

Action Item: Better define the compounds and their impact.

Comment: $\quad$ Deferred as part of feed preparation/pretreatment; see \#1.

Item Number: 90

Node: $\quad$ PBR Offgas Cooler (12.3)

Deviation: Tube leak or rupture.

Risk Level: $\quad 4-F i n a n c i a l$

Action Item: Put E-112 in a low spot

Comment: May not be desirable but will be evaluated during detailed design..

Item Number: 91

Node: $\quad$ PBR Offgas Cooler (12.3)

Deviation: Tube leak or rupture.

Risk Level: $\quad 4$-Financial

Action Item: Consider some way to detect pinhole leaks.

Item Number: 96

Node: $\quad$ Waste Feed Drum (26.1)

Deviation: High pressure

Risk Level: 3-Safety

Action Item: Detail design to address this issue.

Comment: $\quad$ Part of feed preparation/pretreatment; see \#1.

Item Number: 97

Node: $\quad$ Waste Feed Drum (26.2)

Deviation: High concentration of contaminants

Risk Level: $\quad 3-$ General

4 -Safety, Environmental

Action Item: Consider addition of solvent to drum.

Comment: See \#1; solvent addition would be part of the overall feed preparation and pretreatment process.

Item Number: 98

Node: $\quad$ Waste Feed Drum (26.2)

Deviation: High concentration of contaminants

Risk Level: 3-General

4-Safety, Environmental

Action Item: Consider opening and sampling drum under containment.

Comment: $\quad$ Part of feed preparation/pretreatment; see \#1. 


\section{Table C-5 (continued). Resolution of PBR HAZOP Action Items}

\section{Detail Design Items (continued)}

Item Number: 99

Node: $\quad$ Waste Feed Drum (26.4)

Deviation: Maintenance/sampling

Risk Level: 2-Safety

Action Item: Consider use of mobile laboratory.

Comment: $\quad$ Part of feed preparation/pretreatment; see \#1.

Item Number: 100

Node: $\quad$ Waste Feed Drum (26.4)

Deviation: Maintenance/sampling

Risk Level: 2-Safety

Action Item: Consider whether sites will be required to characterize wastes.

Comment: Discussed in DDR but will be part of overall feed preparation/pretreatment; see \#1.

Item Number: 101

Node: $\quad$ Waste Feed Tank Relief Line (25.2)

Deviation: Low/no flow

Risk Level: 3-Safety

Action Item: Confirm that the MOC of relief devices are adequate.

Comment: Pipe spec is a good general MOC guideline, although sometimes relief devices may have to be better material than the piping because of their stagnant installation and critical availability requirement.

Item Number: 102

Node: $\quad$ Waste Feed Tank Relief Line (25.2)

Deviation: Low/no flow

Risk Level: $\quad 3$-Safety

Action Item: Confirm that the rupture disk has vacuum support.

Comment: $\quad$ Add to specification of PSE.

Item Number: 106

Node: $\quad$ PBR Relief Line (23.1)

Deviation: High flow

Risk Level: $\quad 4$-Environmental

Action Item: Consider making rupture disk out of Tantalum.

Comment: $\quad$ Tantalum is ideal MOC for chloride resistance; see \#101.

Item Number: 108

Node: $\quad$ PBR Relief Line (23.2)

Deviation: Low/no flow

Risk Level: $\quad 3-$ Safety

Action Item: MOC of rupture disk.

Comment: $\quad$ See \#106. 
Table C-5 (continued). Resolution of PBR HAZOP Action ltems

\section{Detail Design Items (continued)}

Item Number: 109

Node:

PBR Relief Line (23.3)

Deviation: Reverse flow

Risk Level: 4 Safety

Action Item: PSE 100-10 should have vacuum support.

Comment: Add to specification of PSE.

Item Number: 116

Node: $\quad$ Acid-Gas Scrubber (17.1)

Deviation: High flow

Risk Level: $\quad 4$-Environmental, General

Action Item: Confirm capacity of AC-420 is less than flooding velocity in scrubber.

Comment: Resolve when detailed data is available.

Item Number: 117

Node: $\quad$ Acid-Gas Scrubber (17.5)

Deviation: High pressure

Risk Level: $\quad 4$-Environmental, General

Action Item: Consider increasing pressure rating of S-300.

Comment: Review with scrubber vendors to see what design pressure is practical.

Item Number: 119

Node: $\quad$ Acid-Gas Scrubber (17.5)

Deviation: High pressure

Risk Level: $\quad 4$-Environmental, General

Action Item: Consider vacuum relief on S-300.

Comment: If required.

Item Number: 120

Node: $\quad$ Acid-Gas Scrubber (17.6)

Deviation: Low pressure

Risk Level: 4-Environmental, General

Action Item: Confirm vacuum rating of S-300 is greater than maximum suction of B-320.

Comment: $\quad$ After info on blower and scrubber available; addition of vacuum breaker (see \#119) may be required if satisfactory resolution of this item is not possible.

Item Number: 126

Node: $\quad$ Acid-Gas Scrubber Pump (18.5)

Deviation: Startup

Risk Level: 4 -General

Action Item: Determine initial scrubber liquid level required for pump operation.

Comment: Need pump NPSH requirement and liquid holdup in packing. 


\section{Detail Design Items (continued)}

Item Number: 141

Node: $\quad$ Scrubber Blowdown Line (21.6)

Deviation: High concentration of contaminants

Risk Level: 3-General

Action Item: Evaluate sampling for rad and metals.

Item Number: 152

Node: $\quad$ Caustic to Waste Feed Tank (3.6)

Deviation: Maintenance/sampling

Risk Level: 3-Safety

Action Item: Evaluate servicing requirements of pump.

Comment: After pump info is available.

\section{SOP Items}

Item Number: 9

Node: Waste Drum Feed Line (1.2)

Deviation: Reverse flow

Risk Level: 2-Safety, Environmental

Action Item: SOPs specify one valve to be closed until pump starts.

Item Number: 15

Node: $\quad$ Waste Drum Feed Line (1.7)

Deviation: Loss of containment

Risk Level: $\quad 4$-Safety, Environmental

Action Item: Requirement to pressure-test line after maintenance.

Item Number: 16

Node: $\quad$ Waste Drum Feed Line (1.7)

Deviation: Loss of containment

Risk Level: $\quad 4-$ Safety, Environmental

Action Item: Evaluate PPE requirements.

Comment: Will be part of overall feed preparation/pretreatment; see \#1.

Item Number: 20

Node: $\quad$ Sulfuric Acid Supply Line (2.4)

Deviation: Loss of containment

Risk Level: 3-Safety

Action Item: Consider hooking up acid only when needed (do not leave it hooked up when not in use). 
Table C-5 (continued). Resolution of PBR H,4ZOP Action Items

SOP Items (continued)

Item Number: 55

Node: $\quad$ Waste Feed to PBR (6.2)

Deviation: Low/no flow

Risk Level: 4-Safety

Action Item: Consider using single nozzle for high-energy (exothermic) wastes

Comment: This would apply if such wastes were to be fed at a rate less than $15 \mathrm{gal} / \mathrm{d}$ so that atomization might not be adequate if the flow is split among all three nozzles; the control system is designed to allow this (see \#49 and \#59).

Item Number: 67

Node: $\quad$ Air Feed to PBR (7.6)

Deviation: Shutdown

Risk Level: $\quad 3$-Environmental

Action Item: SOP to provide for gradual reduction of air flow when PBR is being shut down.

Item Number: 78

Node: $\quad$ Packed Bed Reactor (8.10)

Deviation: Shutdown

Risk Level: 2-Environmental

Action Item: SOPs to specify feeding air until $\mathrm{CO} 2$ goes to acceptable minimum.

Comment: $\quad \mathrm{CO} 2$ analyzer has been added; "acceptable minimum" needs to be defined.

Item Number: 85

Node: $\quad$ Quench Chamber (11.6)

Deviation: Startup

Risk Level: $\quad 2-$ General

Action Item: SOP should provide for gradual introduction of waste feed.

Item Number: 86

Node: $\quad$ Quench Chamber (11.6)

Deviation: Startup

Risk Level: $\quad 2-$ General

Action Item: Verify that the startup procedure is valid.

Item Number: 87

Node: $\quad$ Quench Chamber (11.7)

Deviation: Shutdown

Risk Level: $\quad 2-$ General

Action Item: SOP includes continuing to feed air for some period after stopping waste feed,

Item Number: 95

Node: $\quad$ SDP Bypass (14.1)

Deviation: High flow

Risk Level: 3-Environmental

Action Items: Consider administrative controls on activation of bypass line. 
Table C-5 (continued). Resolution of PBR HAZOP Action Items

SOP Items (continued)

Item Number: 105

Node: $\quad$ Waste Feed Tank Relief Line (25.2)

Deviation: Low/no flow

Risk Level: 3-Safety

Action Item: Consider testing relief devices each time the MTU is set up at a new site.

Item Number: 110

Node: . PBR Relief Line (23.4)

Deviation: High concentration of contaminants

Risk Level: $\quad 4-$ Safety

Action Item: Inspect PSE inlet line each time the MTU is set up at a new site.

Item Number: 137

Node: $\quad$ Scrubber Blowdown Line (21.4)

Deviation: High temperature

Risk Level: 4-Environmental

Action Item: SOPs to specify use of only drums rated for $212^{\circ} \mathrm{F}$ or higher.

Item Number: 138

Node: $\quad$ Scrubber Blowdown Line (21.5)

Deviation: Low pressure

Risk Level: 3-Environmental

Action Item: SOPs to specify that drum will be allowed to cool prior to being sealed.

Item Number: 149

Node: $\quad$ Caustic to Waste Feed Tank (3.4)

Deviation: Loss of containment

Risk Level: $\quad 3-$ Safety

Action Item: Consider hooking up caustic only when needed (do not leave it hooked up when not in use). 
This page intentionally blank

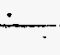


Appendix D

Stream Sheets 
This page intentionally blank 


\section{Stream Sheets}

This Appendix contains stream sheets that give mass and volumetric flow rates, temperatures, and pressures for the PBR/SDP MTU. Data are supplied for all three of the design cases (see Tables 1-1 through 1-3) upon which the design is based. Stream sheets are supplied for all lines shown on the P\&IDs (Appendix A) except those that do not normally have flow. Table D-1 lists the lines that normally have a zero flow.

Table D-1. Zero Flow Lines

\begin{tabular}{||l|l||}
\hline \multicolumn{1}{|c|}{ Line No. } & \multicolumn{1}{|c|}{ Description } \\
\hline \hline 1 1"-2.6B-002-3 & Waste Transfer Blowdown Line \\
\hline 2"-2.6B-016-6 & T-010 Pressure Relief Line \\
\hline $1 "-2.6 A-100-5$ & R-100 Pressure Relief Line \\
\hline $1 "-2.6 B-140-1$ & E-140 Outlet to T-142 \\
\hline 1"-2.6B-142-1 & T-142 Outlet to F-144 \\
\hline $1 "-2.6 B-144-1$ & F-144 Outlet to Vent \\
\hline $1 / 4 "-2.6 C-304-3$ & Sodium Hydroxide Supply to T-010 \\
\hline $1 / 4 "-2.6 C-410-1$ & Sulfuric Acid Supply to T-010 \\
\hline $1 / 4 "-2.6 C-430-1$ & Antifoam Supply to T-010 \\
\hline \hline
\end{tabular}


This page intentionally blank 
Table D-2. Stream Sheets

\begin{tabular}{|c|c|c|c|c|c|}
\hline \multirow[t]{2}{*}{ PROCESS STREAM SHEET } & \multicolumn{3}{|c|}{ Line No. $1 "-2.6 B-002-01 / 02$} & & \\
\hline & Revision & Approval & & & \multirow[b]{2}{*}{ PBR/SDP } \\
\hline \multirow{6}{*}{$\begin{array}{l}\text { NOTES: } \\
\text { Waste Unloading Line to Waste } \\
\text { Feed Tank }\end{array}$} & & & & PROJECT: & \\
\hline & & & & PREPARER: & $R R$ \\
\hline & & & & DATE: & $2 / 13 / 96$ \\
\hline & \multicolumn{3}{|c|}{ Drawing No. E03456 } & & \\
\hline & System: & Waste Feed & & Line Size: & 1 \\
\hline & & \multicolumn{3}{|c|}{ CASE NAME } & \\
\hline COMPOSITION & UNITS & Case 1 & Case 2 & Case 3 & \\
\hline $\mathrm{C}_{20} \mathrm{H}_{42} \mathrm{Oil}$ & $\mathrm{lb} / \mathrm{h}$ & 6,257 & 0 & of & \\
\hline PCB 1242 & $\mathrm{Ib} / \mathrm{h}$ & 0 & 10,410 & 0 & \\
\hline Water & $\mathrm{lb} / \mathrm{h}$ & 0 & of & 7,512 & \\
\hline TOTAL & $\mathrm{lb} / \mathrm{h}$ & 6,257 & 10,410 & 7,512 & \\
\hline & & & & & \\
\hline PROPERTIES & & & & & \\
\hline Temperature & ${ }^{\circ} \mathrm{F}$ & 70 & 70 & 70 & \\
\hline Pressure & psia & 25 & 25 & 25 & \\
\hline Density & $\mathrm{lb} / \mathrm{ft}^{3}$ & 52.00 & 86.52 & 62.43 & \\
\hline Molecular Weight & $\mathrm{lb} / \mathrm{lb}$-mole & 282.55 & 291.99 & 18.015 & \\
\hline Viscosity & $\mathrm{cP}$ & 0.650 & & & \\
\hline & & & & & \\
\hline FLOWS & & & & & \\
\hline Mass Flow & $\mathrm{lb} / \mathrm{h}$ & 6,257 & 10,410 & 7,512 & \\
\hline Volumetric - Actual (liquid) & $\mathrm{gal} / \mathrm{min}$ & 15.00 & 15.00 & 15.00 & \\
\hline Fluid Velocity & $\mathrm{t} / \mathrm{s}$ & 6.1 & 6.1 & 6.1 & \\
\hline
\end{tabular}


Table D-2 (continued). Stream Sheets

\begin{tabular}{|c|c|c|c|c|c|}
\hline \multirow[t]{2}{*}{ PROCESS STREAM SHEET } & \multicolumn{3}{|c|}{ Line No. $1 / 2^{\prime \prime}-2.6 C-010-01$} & & \\
\hline & Revision & Approval & & & \\
\hline \multirow{6}{*}{$\begin{array}{l}\text { NOTES: } \\
\text { Waste Feed Header to PBR }\end{array}$} & & & & PROJECT: & PBR/SDP \\
\hline & & & & PREPARER: & $\mathrm{RR}$ \\
\hline & & & & DATE: & 2/13/96 \\
\hline & \multicolumn{3}{|c|}{ Drawing No. E03456 } & & \\
\hline & \multirow[t]{2}{*}{ System: . } & \multicolumn{2}{|l|}{ Waste Feed } & Line Size: & 0.5 \\
\hline & & \multicolumn{3}{|c|}{ CASE NAME } & \\
\hline COMPOSITION & UNITS & Case 1 & Case 2 & Case 3 & \\
\hline $\mathrm{C}_{20} \mathrm{H}_{42} \mathrm{Oil}$ & $\mathrm{lb} / \mathrm{h}$ & 4.34 & 0 & 0 & \\
\hline PCB 1242 & $\mathrm{lb} / \mathrm{h}$ & 0 & 7.22 & 0 & \\
\hline Water & $\mathrm{lb} / \mathrm{h}$ & 0 & 0 & 26.05 & \\
\hline TOTAL & $\mathrm{lb} / \mathrm{h}$ & 4.34 & 7.22 & 26.05 & \\
\hline & & & & & \\
\hline \multicolumn{6}{|l|}{ PROPERTIES } \\
\hline Temperature & ${ }^{\circ} \mathrm{F}$ & 70 & 70 & 70 & \\
\hline Pressure & psia & 25 & 25 & 25 & \\
\hline Density & $\mathrm{Ib} / \mathrm{ft}^{3}$ & 52 & 86.52 & 62.43 & \\
\hline Molecular Weight & $\mathrm{lb} / \mathrm{lb}$-mole & 282.55 & 291.99 & 18.02 & \\
\hline Viscosity & $\mathrm{cP}$ & 0.65 & 0 & 0 & \\
\hline \multicolumn{6}{|l|}{ FLOWS } \\
\hline Mass Flow & $\mathrm{lb} / \mathrm{h}$ & 4.34 & 7.22 & 26.05 & \\
\hline Volumetric - Actual (liquid) & $\mathrm{gal} / \mathrm{d}$ & 15.00 & 15.00 & 75.00 & \\
\hline Fluid Velocity & $\mathrm{ft} / \mathrm{s}$ & 0.02 & 0.02 & 0.09 & \\
\hline
\end{tabular}


Table D-2 (continued). Stream Sheets

\begin{tabular}{|c|c|c|c|c|c|}
\hline \multirow[t]{2}{*}{ PROCESS STREAM SHEET } & \multicolumn{3}{|c|}{ Line No. $1 / 2^{\prime \prime}-2.6 \mathrm{C}-010-02$} & & \\
\hline & Revision & Approval & & & \\
\hline \multirow{6}{*}{$\begin{array}{l}\text { NOTES: } \\
\text { Waste Feed Tank Vent Line }\end{array}$} & & & & PROJECT: & PBR/SDP \\
\hline & & & & PREPARER: & $\mathrm{RR}$ \\
\hline & & & & DATE: & $2 / 13 / 96$ \\
\hline & \multicolumn{3}{|c|}{ Drawing No. E03456, E03457 } & & \\
\hline & \multirow[t]{2}{*}{ System: } & \multicolumn{2}{|c|}{ Waste Feed Tank } & Line Size: & 0.5 \\
\hline & & \multicolumn{3}{|c|}{ CASE NAME } & \\
\hline COMPOSITION & UNITS & Case 1 & Case 2 & Case 3 & \\
\hline Air & $\mathrm{lb} / \mathrm{h}$ & 19.20 & 19.20 & 19.20 & \\
\hline & & & & & \\
\hline TOTAL & $\mathrm{lb} / \mathrm{h}$ & 19.20 & 19.20 & 19.20 & \\
\hline & & & & & \\
\hline \multicolumn{6}{|l|}{ PROPERTIES } \\
\hline Temperature & ${ }^{\circ} \mathrm{F}$ & 70 & 70 & 70 & \\
\hline Pressure & psia & 31.3 & 31.3 & 31.3 & \\
\hline Density & $\mathrm{lb} / \mathrm{ft}^{3}$ & 0.160 & 0.160 & 0.160 & \\
\hline Molecular Weight & lb/h-mole & 29 & 29 & 29 & \\
\hline Viscosity & $\mathrm{CP}$ & 0.018 & 0.018 & 0.018 & \\
\hline \multirow{2}{*}{\multicolumn{6}{|c|}{ FLOWS }} \\
\hline & & & & & \\
\hline Mass Flow & $\mathrm{Ib} / \mathrm{h}$ & 19.20 & 19.20 & 19.20 & \\
\hline Volumetric - Actual (vapor) & acfm & 2.01 & 2.01 & 2.01 & \\
\hline Volumetric - Standard & scfm & .4 .19 & 4.19 & 4.19 & \\
\hline Fluid Velocity & $\mathrm{ft} / \mathrm{s}$ & 24.5 & 24.5 & 24.5 & \\
\hline
\end{tabular}


Table D-2 (continued). Stream Sheets

\begin{tabular}{|c|c|c|c|c|c|}
\hline \multirow[t]{2}{*}{ PROCESS STREAM SHEET } & \multicolumn{3}{|c|}{ Line No. $1 / 2 "-2.6 C-010-03 / 04 / 05$} & & \\
\hline & Revision & Approval & & & \\
\hline \multirow{6}{*}{$\begin{array}{l}\text { NOTES: } \\
\text { Waste Feed to P-020/022/024 } \\
\text { Properties are the same for lines } \\
1 / 2^{\prime \prime}-2.6 C-020 / 022 / 024-01\end{array}$} & & & & PROJECT: & PBR/SDP \\
\hline & & & & PREPARER: & RR \\
\hline & & & & DATE: & $2 / 13 / 96$ \\
\hline & \multicolumn{3}{|c|}{ Drawing No. E03457 } & & \\
\hline & \multicolumn{3}{|c|}{ System: - Waste Feed } & Line Size: & 0.5 \\
\hline & & \multicolumn{3}{|c|}{ CASE NAME } & \\
\hline COMPOSITION & UNITS & Case 1 & Case 2 & Case 3 & \\
\hline $\mathrm{C}_{20} \mathrm{H}_{42} \mathrm{Oil}$ & $\mathrm{lb} / \mathrm{h}$ & 1.45 & 0 & 0 & \\
\hline PCB 1242 & $\mathrm{lb} / \mathrm{h}$ & 0 & 2.41 & 0 & \\
\hline Water & $\mathrm{lb} / \mathrm{h}$ & 0 & 0 & 8.68 & \\
\hline TOTAL & $\mathrm{Ib} / \mathrm{h}$ & 1.45 & 2.41 & 8.68 & \\
\hline \multirow{2}{*}{\multicolumn{6}{|c|}{ PROPERTIES }} \\
\hline & & & & & \\
\hline Temperature & ${ }^{\circ} \mathrm{F}$ & 70 & 70 & 70 & \\
\hline Pressure & psia & 25 & 25 & 25 & \\
\hline Density & $\mathrm{lb} / \mathrm{ft}^{3}$ & 52 & 86.52 & 62.43 & \\
\hline Molecular Weight & $\mathrm{lb} / \mathrm{bb}$-mole & 282.55 & 291.99 & 18.02 & \\
\hline Viscosity & $\mathrm{cP}$ & 0.65 & 0 & 0 & \\
\hline \multicolumn{6}{|l|}{ FLOWS } \\
\hline Mass Flow & $\mathrm{lb} / \mathrm{h}$ & 1.45 & 2.41 & 8.68 & \\
\hline Volumetric - Actual (liquid) & gal/d & 5.00 & 5.00 & 25.00 & \\
\hline Fluid Velocity & $\mathrm{ft} / \mathrm{s}$ & 0.01 & 0.01 & 0.03 & \\
\hline
\end{tabular}


Table D-2 (continued). Stream Sheets

\begin{tabular}{|c|c|c|c|c|c|}
\hline \multirow[t]{2}{*}{ PROCESS STREAM SHEET } & \multirow{2}{*}{$\frac{\text { Line No. }}{\text { Revision }}$} & \multicolumn{2}{|c|}{$3 / 4^{4}-2.6 \mathrm{D}-100-01$} & & \\
\hline & & Approval & & & \\
\hline \multirow{6}{*}{$\begin{array}{l}\text { NOTES: } \\
\text { Atomizing Air to PBR R-100 } \\
\text { Same properties apply to line } \\
3 / 4^{\prime \prime}-2.6 \mathrm{D}-420-04\end{array}$} & & & & PROJECT: & PBR/SDP \\
\hline & & & & PREPARER: & RR \\
\hline & & & & DATE: & $3 / 8 / 96$ \\
\hline & \multicolumn{3}{|c|}{ Drawing No. E03457, E03459 } & & \\
\hline & \multirow[t]{2}{*}{ System: } & \multicolumn{2}{|c|}{ PBR } & Line Size: & 0.75 \\
\hline & & \multicolumn{3}{|c|}{ CASE NAME } & \\
\hline COMPOSITION & UNITS & Case 1 & Case 2 & Case 3 & \\
\hline Air & $\mathrm{lb} / \mathrm{h}$ & 183.35 & 183.35 & 183.35 & \\
\hline TOTAL & $\mathrm{lb} / \mathrm{h}$ & 183.35 & 183.35 & 183.35 & \\
\hline \multicolumn{6}{|l|}{ PROPERTIES } \\
\hline Temperature & ${ }^{\circ} \mathrm{F}$ & 70 & 70 & 70 & \\
\hline Pressure & psia & 71.3 & 71.3 & 71.3 & \\
\hline Density & $\mathrm{lb} / \mathrm{ft}^{3}$ & 0.364 & 0.364 & 0.364 & \\
\hline Molecular Weight & $\mathrm{lb} / \mathrm{b}$-mole & 29 & 29 & 29 & \\
\hline Viscosity & $\mathbf{c P}$ & 0.018 & 0.018 & 0.018 & \\
\hline \multicolumn{6}{|l|}{ FLOWS } \\
\hline Mass Flow & $\mathrm{lb} / \mathrm{h}$ & 183.35 & 183.35 & 183.35 & \\
\hline Volumetric - Actual (vapor) & acfm & 8.40 & 8.40 & 8.40 & \\
\hline Volumetric - Standard & scfm & 40.00 & 40.00 & 40.00 & \\
\hline Fluid Velocity & $\mathrm{ft} / \mathrm{s}$ & 45.7 & 45.7 & 45.7 & \\
\hline
\end{tabular}


Table D-2 (continued). Stream Sheets

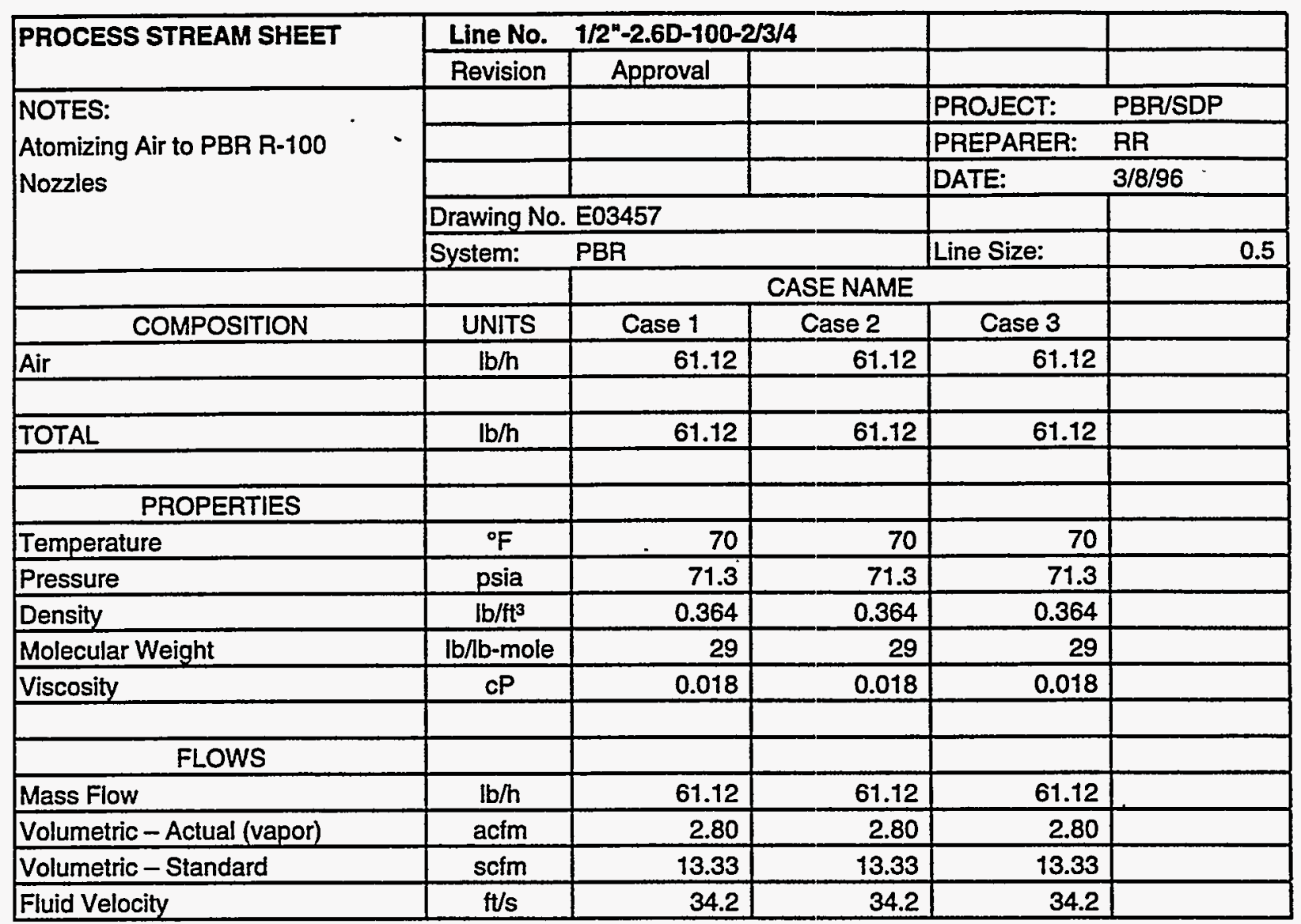


Table D-2 (continued). Stream Sheets

\begin{tabular}{|c|c|c|c|c|c|}
\hline \multirow[t]{2}{*}{ PROCESS STREAM SHEET } & \multicolumn{3}{|c|}{ Line No. $1 / 4^{\prime \prime}-2.6 \mathrm{D}-110-1$} & & \\
\hline & Revision & Approval & & & \\
\hline \multirow{6}{*}{$\begin{array}{l}\text { NOTES: } \\
\text { Quench Water Supply to E-110 }\end{array}$} & & & & PROJECT: & PBR/SDP \\
\hline & & & & PREPARER: & RR \\
\hline & & & & DATE: & $3 / 8 / 96$ \\
\hline & \multicolumn{3}{|c|}{ Drawing No. E03457, E03458 } & & \\
\hline & \multicolumn{3}{|c|}{ System: $\quad$ PBR Quench } & & 0.25 \\
\hline & & & & & \\
\hline COMPOSITION & UNITS & Case 1 & Case 2 & Case 3 & \\
\hline Water & $\mathrm{lb} / \mathrm{h}$ & 0 & 17.5 & 0 & \\
\hline TOTAL & $\mathrm{lb} / \mathrm{h}$ & 0 & 17.5 & 0 & \\
\hline & & & & & \\
\hline \multicolumn{6}{|l|}{ PAOPERTIES } \\
\hline Temperature & ${ }^{\circ} \mathrm{F}$ & 70 & 70 & 70 & \\
\hline Pressure & psia & 25 & 25 & 25 & \\
\hline Density & $\mathrm{lb} / \mathrm{ft}^{3}$ & 62.43 & 62.43 & 62.43 & \\
\hline Molecular Weight & $\mathrm{lb} / \mathrm{lb}-\mathrm{mole}$ & 18.015 & 18.015 & 18.015 & \\
\hline Viscosity & $\mathrm{CP}$ & & & & \\
\hline \multicolumn{6}{|l|}{ FLOWS: } \\
\hline Mass Flow & $\mathrm{Ib} / \mathrm{h}$ & 0 & 17.5 & 0 & \\
\hline Volumetric - Actual (liquid) & $\mathrm{gal} / \mathrm{min}$ & 0.00 & 0.035 & 0.00 & \\
\hline Fluid Velocity & $\mathrm{ft} / \mathrm{s}$ & 0.0 & 0.2 & 0.0 & \\
\hline
\end{tabular}


Table D-2 (continued). Stream Sheets

\begin{tabular}{|c|c|c|c|c|c|}
\hline \multirow[t]{2}{*}{ PROCESS STREAM SHEET } & \multicolumn{3}{|c|}{ Line No. $3^{\prime \prime}-2.6 A-110-2$} & & \\
\hline & Revision & Approval & & & \\
\hline \multirow{6}{*}{$\begin{array}{l}\text { NOTES: } \\
\text { Quench Chamber E-110 to PBR } \\
\text { Offgas Cooler E-112 }\end{array}$} & & & : & PROJECT: & PBR/SDP \\
\hline & & & & PREPARER: & RR \\
\hline & & & & DATE: & 2/13/96 \\
\hline & \multicolumn{3}{|c|}{ Drawing No. E03457 } & & \\
\hline & \multicolumn{3}{|c|}{ System: . PBR } & Line Size: & 3 \\
\hline & \multicolumn{4}{|c|}{ CASE NAME } & \\
\hline COMPOSITION & UNITS & Case 1 & Case 2 & Case 3 & \\
\hline Nitrogen & $\mathrm{lb} / \mathrm{h}$ & 139.89 & 139.89 & 139.89 & \\
\hline Oxygen & $\mathrm{lb} / \mathrm{h}$ & 27.47 & 30.8 & 42.48 & \\
\hline Carbon Dioxide & $\mathrm{lb} / \mathrm{h}$ & 13.53 & 14.82 & 0 & \\
\hline Water & $\mathrm{lb} / \mathrm{h}$ & 5.82 & 18.51 & 26.08 & \\
\hline Hydrogen Chloride & $\mathrm{Ib} / \mathrm{h}$ & & 3.07 & & \\
\hline TOTAL & $\mathrm{lb} / \mathrm{h}$ & 186.71 & 207.09 & 208.45 & \\
\hline \multicolumn{6}{|l|}{ PROPERTIES } \\
\hline Temperature & ${ }^{\circ} \mathrm{F}$ & 932 & 482 & 932 & \\
\hline Pressure & psia & 10.85 & 10.85 & 10.85 & \\
\hline Density & $\mathrm{lb} / \mathrm{ft}^{3}$ & 0.021 & 0.030 & 0.019 & \\
\hline Molecular Weight & $\mathrm{lb} / \mathrm{lb}-\mathrm{mole}$ & 28.800 & 27.968 & 26.831 & \\
\hline Viscosity & $\mathrm{cP}$ & 0.0341 & 0.025 & 0.034 & \\
\hline \multicolumn{6}{|l|}{ FLOWS } \\
\hline Mass Flow & $\mathrm{lb} / \mathrm{h}$ & 186.71 & 207.09 & 208.45 & \\
\hline Volumetric - Actual (vapor) & $\mathrm{acfm}$ & 148.74 & 114.97 & 178.25 & \\
\hline Volumetric - Standard & scfm & 41.01 & 46.84 & 49.15 & \\
\hline Fluid Velocity & $\mathrm{ft} / \mathrm{s}$ & 50.5 & 39.0 & 60.5 & \\
\hline
\end{tabular}


Table D-2 (continued). Stream Sheets

\begin{tabular}{|c|c|c|c|c|c|}
\hline \multirow[t]{2}{*}{ PROCESS STREAM SHEET } & \multicolumn{3}{|c|}{ Line No. 3/4"-2.6D-112-1 } & & \\
\hline & Revision & Approval & & & \\
\hline \multirow{5}{*}{$\begin{array}{l}\text { NOTES: } \\
\text { Cooling Water Supply to E-112 } \\
\text { Properties are the same for lines } \\
3 / 4^{\prime \prime}-2.6 D-400-1 \\
3 / 4^{\prime \prime}-2.6 D-402-1\end{array}$} & & & & PROJECT: & PBR/SDP \\
\hline & & & & PREPARER: & $\mathrm{RR}$ \\
\hline & & & & DATE: & $3 / 8 / 96$ \\
\hline & \multicolumn{3}{|c|}{ Drawing No. E03457, E03489 } & & \\
\hline & \multirow[t]{2}{*}{ System: } & \multicolumn{2}{|l|}{ PBR Offgas } & Line Size: & 0.75 \\
\hline & & \multicolumn{3}{|c|}{ CASE NAME } & \\
\hline COMPOSITION & UNITS & Case 1 & Case 2 & Case 3 & \\
\hline Water & $\mathrm{Ib} / \mathrm{h}$ & 1,667 & 643 & 2,006 & \\
\hline TOTAL & $\mathrm{lb} / \mathrm{h}$ & 1,667 & 643 & 2,006 & \\
\hline PROPERTIES & & & & & - \\
\hline Temperature & ${ }^{\circ} \mathrm{F}$ & 95 & 95 & 95 & \\
\hline Pressure & psia & 25 & 25 & 25 & \\
\hline Density & $\mathrm{lb} / \mathrm{ft}^{3}$ & 62.06 & 62.06 & 62.06 & \\
\hline Molecular Weight & $\mathrm{lb} / \mathrm{lb}$-mole & 18.015 & 18.015 & 18.015 & \\
\hline Viscosity & $\mathrm{CP}$ & & & & \\
\hline FLOWS & & & & & \\
\hline Mass Flow & $\mathrm{Ib} / \mathrm{h}$ & 1,667 & 643 & 2,006 & \\
\hline Volumetric - Actual (liquid) & $\mathrm{gal} / \mathrm{min}$ & 3.35 & 1.292 & 4.03 & \\
\hline Fluid Velocity & $\mathrm{ft} / \mathrm{s}$ & $\therefore 2.4$ & 0.9 & 2.9 & \\
\hline
\end{tabular}


Table D-2 (continued). Stream Sheets

\begin{tabular}{|c|c|c|c|c|c|}
\hline \multirow[t]{2}{*}{ PROCESS STREAM SHEET } & \multicolumn{3}{|c|}{ Line No. $3 / 4^{\prime \prime}-2.6 \mathrm{D}-112-2$} & & \\
\hline & Revision & Approval & & & \multirow[b]{2}{*}{ PBR/SDP } \\
\hline \multirow{6}{*}{$\begin{array}{l}\text { NOTES: } \\
\text { Cooling Water Return from E-112 }\end{array}$} & & & & PROJECT: & \\
\hline & & & & PREPARER: & RR \\
\hline & & & & DATE: & $3 / 8 / 96$ \\
\hline & \multicolumn{3}{|c|}{ Drawing No. E03457, E03459 } & \multirow[b]{2}{*}{ Line Size: } & \multirow[b]{2}{*}{0.75} \\
\hline & \multicolumn{3}{|c|}{ System: · PBR Offgas } & & \\
\hline & \multicolumn{4}{|c|}{ CASE NAME } & \\
\hline \multirow[t]{2}{*}{ COMPOSITION } & UNITS & Case 1 & Case 2 & Case 3 & \\
\hline & $\mathrm{lb} / \mathrm{h}$ & 1,667 & 643 & 2,006 & \\
\hline TOTAL & $\mathrm{lb} / \mathrm{h}$ & 1,667 & 643 & 2,006 & \\
\hline \multicolumn{6}{|l|}{$\begin{array}{r}\text { PROPERTIES } \\
\end{array}$} \\
\hline Temperature & ${ }^{\circ} \mathrm{F}$ & 115 & 115 & 115 & \\
\hline Pressure & psia & 25 & 25 & 25 & \\
\hline Density & $\mathrm{lb} / \mathrm{ft}^{3}$ & 61.78 & 61.78 & 61.78 & \\
\hline Molecular Weight & $\mathrm{lb} / \mathrm{lb}$-mole & 18.015 & 18.015 & 18.015 & \\
\hline Viscosity & $\mathrm{cP}$ & & & +2 & \\
\hline \multicolumn{6}{|l|}{ FLOWS } \\
\hline Mass Flow & $\mathrm{lb} / \mathrm{h}$ & 1,667 & 643 & 2,006 & \\
\hline Volumetric - Actual (liquid) & $\mathrm{gal} / \mathrm{min}$ & 3.36 & 1.298 & 4.05 & \\
\hline Fluid Velocity & $\mathrm{ft} / \mathrm{s}$ & 2.4 & 0.9 & 2.9 & \\
\hline
\end{tabular}


Table D-2 (continued). Stream Sheets

\begin{tabular}{|c|c|c|c|c|c|}
\hline \multirow[t]{2}{*}{ PROCESS STREAM SHEET } & \multicolumn{3}{|c|}{ Line No. $2^{n}-2.6 \mathrm{~B}-112-3$} & & \\
\hline & Revision & Approval & & & \multirow[b]{2}{*}{ PBR/SDP } \\
\hline \multirow{7}{*}{$\begin{array}{l}\text { NOTES: } \\
\text { PBR Offgas Cooler E-112 to SDP } \\
\text { Properties are the same for lines: } \\
2^{4}-2.6 \mathrm{~B}-130-02 / 04 \\
2 "-2.6 \mathrm{~B}-120-01 \text { (when in use) } \\
2^{\prime \prime}-2.6 \mathrm{~B}-130-01 / 03 \text { (when in use) }\end{array}$} & & & & PROJECT: & \\
\hline & & & & PREPARER: & $\frac{\text { PBR/SDP }}{\text { RR }}$ \\
\hline & & & & DATE: & $2 / 13 / 96$ \\
\hline & \multicolumn{3}{|c|}{ Drawing No. E03457, E03488 } & & \\
\hline & \multicolumn{3}{|c|}{ System: $\quad$ PBR } & Line Size: & 2 \\
\hline & & & & & \\
\hline & & \multicolumn{3}{|c|}{ CASE NAME } & \\
\hline COMPOSITION & UNITS & Case 1 & Case 2 & Case 3 & \\
\hline Nitrogen & $\mathrm{lb} / \mathrm{h}$ & 139.89 & 139.89 & 139.89 & \\
\hline Oxygen & $\mathrm{lb} / \mathrm{h}$ & 27.47 & 30.8 & 42.48 & \\
\hline Carbon Dioxide & $\mathrm{lb} / \mathrm{h}$ & 13.53 & 14.82 & 0 & \\
\hline Water & $\mathrm{lb} / \mathrm{h}$ & 5.82 & 18.51 & 26.08 & \\
\hline Hydrogen Chloride & $\mathrm{lb} / \mathrm{h}$ & 0 & 3.07 & 0 & \\
\hline TOTAL & $\mathrm{lb} / \mathrm{h}$ & 186.71 & 207.09 & 208.45 & \\
\hline \multirow{2}{*}{\multicolumn{6}{|c|}{ PROPERTIES }} \\
\hline & & & & & \\
\hline Temperature & $\stackrel{\circ F}{P}$ & 248 & 248 & 248 & \\
\hline Pressure & psia & 10.79 & 10.79 & 10.79 & \\
\hline Density & $\mathrm{lb} / \mathrm{ft}^{3}$ & 0.041 & 0.040 & 0.038 & \\
\hline Molecular Weight & $\mathrm{lb} / \mathrm{lb}$-mole & 28.800 & 27.968 & 26.831 & \\
\hline Viscosity & $\mathrm{CP}$ & 0.02 & 0.019 & 0.020 & \\
\hline \multicolumn{6}{|l|}{ FLOWS } \\
\hline Mass Flow & $\mathrm{lb} / \mathrm{h}$ & 186.71 & 207.09 & 208.45 & \\
\hline Volumetric - Actual (vapor) & $\mathrm{acfm}$ & 76.07 & 86.89 & 91.16 & \\
\hline Volumetric - Standard & scfm & 41.01 & 46.84 & 49.15 & \\
\hline Fluid Velocity & $\mathrm{ft} / \mathrm{s}$ & 58.1 & 66.4 & 69.6 & \\
\hline
\end{tabular}


Table D-2 (continued). Stream Sheets

\begin{tabular}{|c|c|c|c|c|c|}
\hline \multirow[t]{2}{*}{ PROCESS STREAM SHEET } & \multicolumn{3}{|c|}{ Line No. $1 "-2.6 B-201 / 202 / 203 / 204-1$} & & \\
\hline & Revision & Approval & & & \\
\hline \multirow{6}{*}{$\begin{array}{l}\text { NOTES: } \\
\text { SDP Cell Inlet Line } \\
\text { Properties are the same for outlet } \\
1^{\prime \prime}-2.6 \mathrm{~B}-201 / 202 / 203 / 204-2\end{array}$} & & & & PROJECT: & PBR/SDP \\
\hline & & & & PREPARER: & $\mathrm{RR}$ \\
\hline & & & & DATE: & $2 / 13 / 96$ \\
\hline & \multicolumn{3}{|c|}{ Drawing No. E03488 } & & \\
\hline & System: & SDP & & Line Size: & 1 \\
\hline & \multicolumn{4}{|c|}{ CASE NAME } & \\
\hline COMPOSITION & UNITS & Case 1 & Case 2 & Case 3 & \\
\hline Nitrogen & $\mathrm{lb} / \mathrm{h}$ & 34.97 & 34.97 & 34.97 & \\
\hline Oxygen & $\mathrm{lb} / \mathrm{h}$ & 6.87 & 7.70 & 10.62 & \\
\hline Carbon Dioxide & $\mathrm{lb} / \mathrm{h}$ & 3.38 & 3.71 & 0 & \\
\hline Water & $\mathrm{lb} / \mathrm{h}$ & 1.46 & 4.63 & 6.52 & \\
\hline Hydrogen Chloride & $\mathrm{lb} / \mathrm{h}$ & 0 & 0.77 & 0 & \\
\hline TOTAL & $\mathrm{lb} / \mathrm{h}$ & 46.68 & 51.77 & 52.11 & \\
\hline & & & & & \\
\hline \multicolumn{6}{|l|}{ PROPERTIES } \\
\hline Temperature & ${ }^{\circ} \mathrm{F}$ & 248 & 248 & 248 & \\
\hline Pressure & psia & 10.79 & 10.79 & 10.79 & \\
\hline Density & $\mathrm{lb} / \mathrm{ft}^{3}$ & 0.041 & 0.040 & 0.038 & \\
\hline Molecular Weight & $\mathrm{lb} / \mathrm{b}$-mole & 28.800 & 27.968 & 26.831 & \\
\hline Viscosity & $\mathrm{cP}$ & 0.02 & 0.019 & 0.020 & \\
\hline \multicolumn{6}{|l|}{ FLOWS } \\
\hline Mass Flow & $\mathrm{lb} / \mathrm{h}$ & 46.68 & 51.77 & 52.11 & \\
\hline Volumetric - Actual (vapor) & acfm & 19.02 & 21.72 & 22.79 & \\
\hline Volumetric - Standard & scfm & 10.25 & 11.71 & 12.29 & \\
\hline Fluid Velocity & $\mathrm{ft} / \mathrm{s}$ & 58.1 & 66.4 & 69.6 & \\
\hline
\end{tabular}


Table D-2 (continued). Stream Sheets

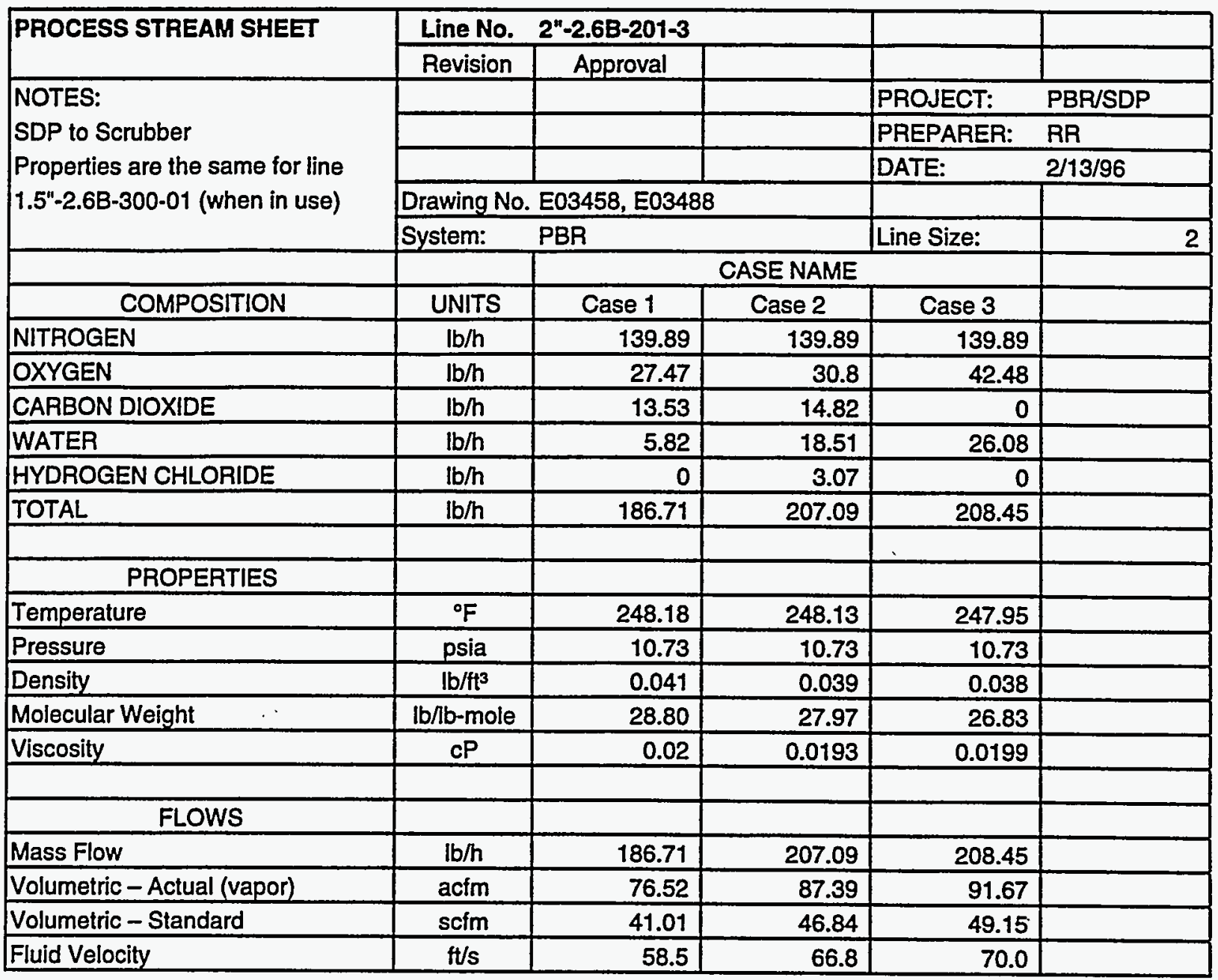


Table D-2 (continued). Stream Sheets

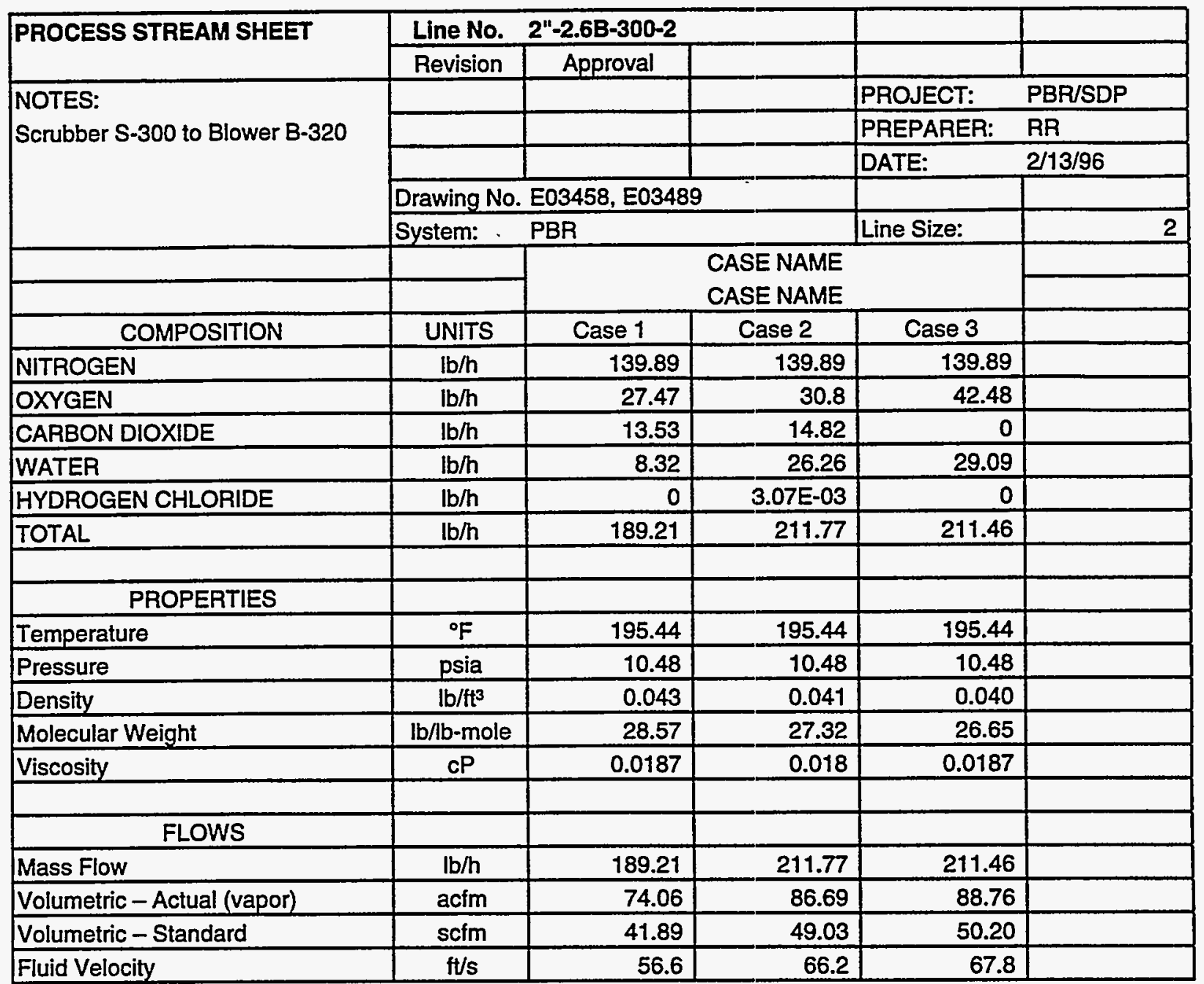


Table D-2 (continued). Stream Sheets

\begin{tabular}{|c|c|c|c|c|c|}
\hline \multirow[t]{2}{*}{ PROCESS STREAM SHEET } & \multicolumn{3}{|c|}{ Line No. $1 / 4^{\prime \prime}-2.6 \mathrm{D}-300-3$} & & \\
\hline & Revision & Approval & & & \multirow[b]{2}{*}{ PBR/SDP } \\
\hline \multirow{6}{*}{$\begin{array}{l}\text { NOTES: } \\
\text { Process Water to Scrubber } 5-300\end{array}$} & & & & PROJECT: & \\
\hline & & & & PREPARER: & RR \\
\hline & & & & DATE: & $3 / 8 / 96$ \\
\hline & \multicolumn{3}{|c|}{ Drawing No. E03458 } & \multirow{3}{*}{ Line Size: } & \\
\hline & \multirow[t]{2}{*}{ System: } & \multicolumn{2}{|l|}{ Scrubber } & & 0.25 \\
\hline & & \multicolumn{2}{|c|}{ CASE NAME } & & \\
\hline COMPOSITION & UNITS & Case 1 & Case 2 & Case 3 & \\
\hline Water & $\mathrm{lb} / \mathrm{h}$ & 2.51 & 22.53 & 3 & \\
\hline TOTAL & $\mathrm{lb} / \mathrm{h}$ & 2.51 & 22.53 & 3.01 & \\
\hline \multicolumn{6}{|l|}{$\begin{array}{r}\text { PROPERTIES } \\
\end{array}$} \\
\hline Temperature & ${ }^{\circ} \mathrm{F}$ & 77 & 77 & 77 & \\
\hline Pressure & psia & 25 & 25 & 25 & \\
\hline Density & $\mathrm{lb} / \mathrm{ft}^{3}$ & 62.25 & 62.25 & 62.25 & \\
\hline Molecular Weight & $\mathrm{lb} / \mathrm{lb}$-mole & 18.015 & 18.015 & 18.015 & \\
\hline Viscosity & $\mathrm{CP}$ & & & & \\
\hline \multicolumn{6}{|l|}{ FLOWS } \\
\hline Mass Flow & $\mathrm{lb} / \mathrm{h}$ & 3 & 22.53 & 3 & \\
\hline Volumetric - Actual (liquid) & $\mathrm{gal} / \mathrm{min}$ & 0.01 & 0.045 & 0.01 & \\
\hline Fluid Velocity & $\mathrm{ft} / \mathrm{s}$ & $=0.0$ & 0.3 & 0.0 & \\
\hline
\end{tabular}


Table D-2 (continued). Stream Sheets

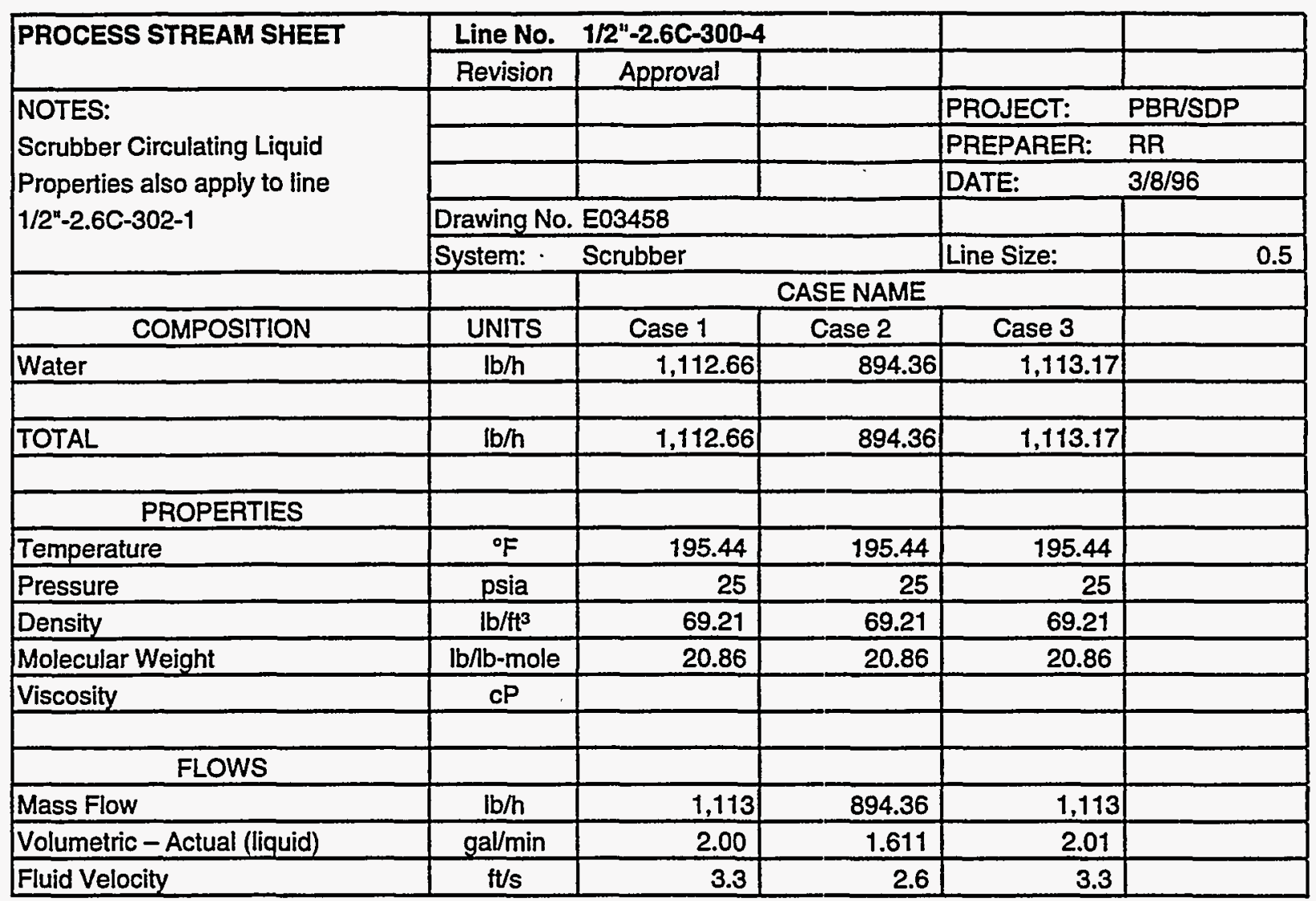


Table D-2 (continued). Stream Sheets

\begin{tabular}{|c|c|c|c|c|c|}
\hline \multirow[t]{2}{*}{ PROCESS STREAM SHEET } & \multicolumn{3}{|c|}{ Line No. $\quad 1 / 2^{\prime \prime}-2.6 \mathrm{C}-302-2$} & & \\
\hline & Revision & Approval & & & \\
\hline \multirow{6}{*}{$\begin{array}{l}\text { NOTES: } \\
\text { Scrubber Blowdown }\end{array}$} & & & & PROJECT: & PBR/SDP \\
\hline & & & & PREPARER: & RR \\
\hline & & & & DATE: & $3 / 8 / 96$ \\
\hline & \multicolumn{3}{|c|}{ Drawing No. EO3458 } & & \\
\hline & \multirow[t]{2}{*}{ System: } & \multicolumn{2}{|l|}{ Scrubber } & Line Size: & 0.5 \\
\hline & & \multicolumn{3}{|c|}{ CASE NAME } & \\
\hline COMPOSITION & UNITS & Case 1 & Case 2 & Case 3 & \\
\hline Water & $\mathrm{lb} / \mathrm{h}$ & 0 & 19.67 & 0 & \\
\hline & & & & & \\
\hline TOTAL & $\mathrm{lb} / \mathrm{h}$ & 0 & 19.67 & 0 & \\
\hline \multicolumn{6}{|l|}{ PROPERTIES } \\
\hline Temperature & ${ }^{\circ} \mathrm{F}$ & 195.44 & 195.44 & 195.44 & \\
\hline Pressure & psia & 25 & 25 & 25 & \\
\hline Density & $\mathrm{lb} / \mathrm{ft}^{3}$ & 69.21 & 69.21 & 69.21 & \\
\hline Molecular Weight & $\mathrm{lb} / \mathrm{lb}$-mole & 20.90 & 20.90 & 20.90 & \\
\hline Viscosity & $\mathrm{cP}$ & & & & \\
\hline & & & & & \\
\hline \multicolumn{6}{|l|}{ FLOWS } \\
\hline Mass Flow & $\mathrm{lb} / \mathrm{h}$ & 0 & 19.67 & 0 & \\
\hline Volumetric - Actual (liquid) & $\mathrm{gal} / \mathrm{min}$ & 0.00 & 0.035 & 0.00 & \\
\hline Fluid Velocity & $\mathrm{ft} / \mathrm{s}$ & 0.0 & 0.1 & 0.0 & \\
\hline
\end{tabular}


Table D-2 (continued). Stream Sheets

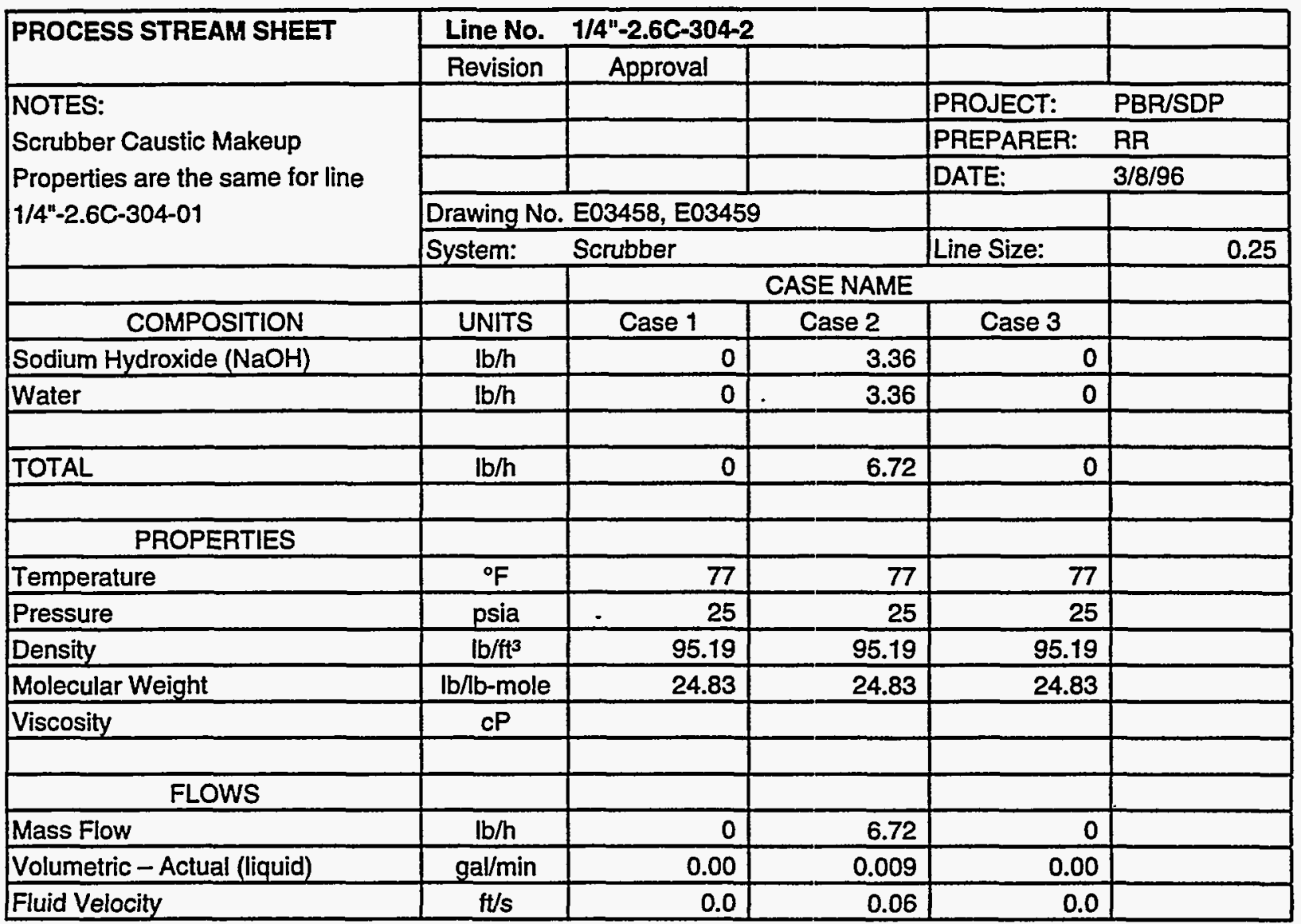


Table D-2 (continued). Stream Sheets

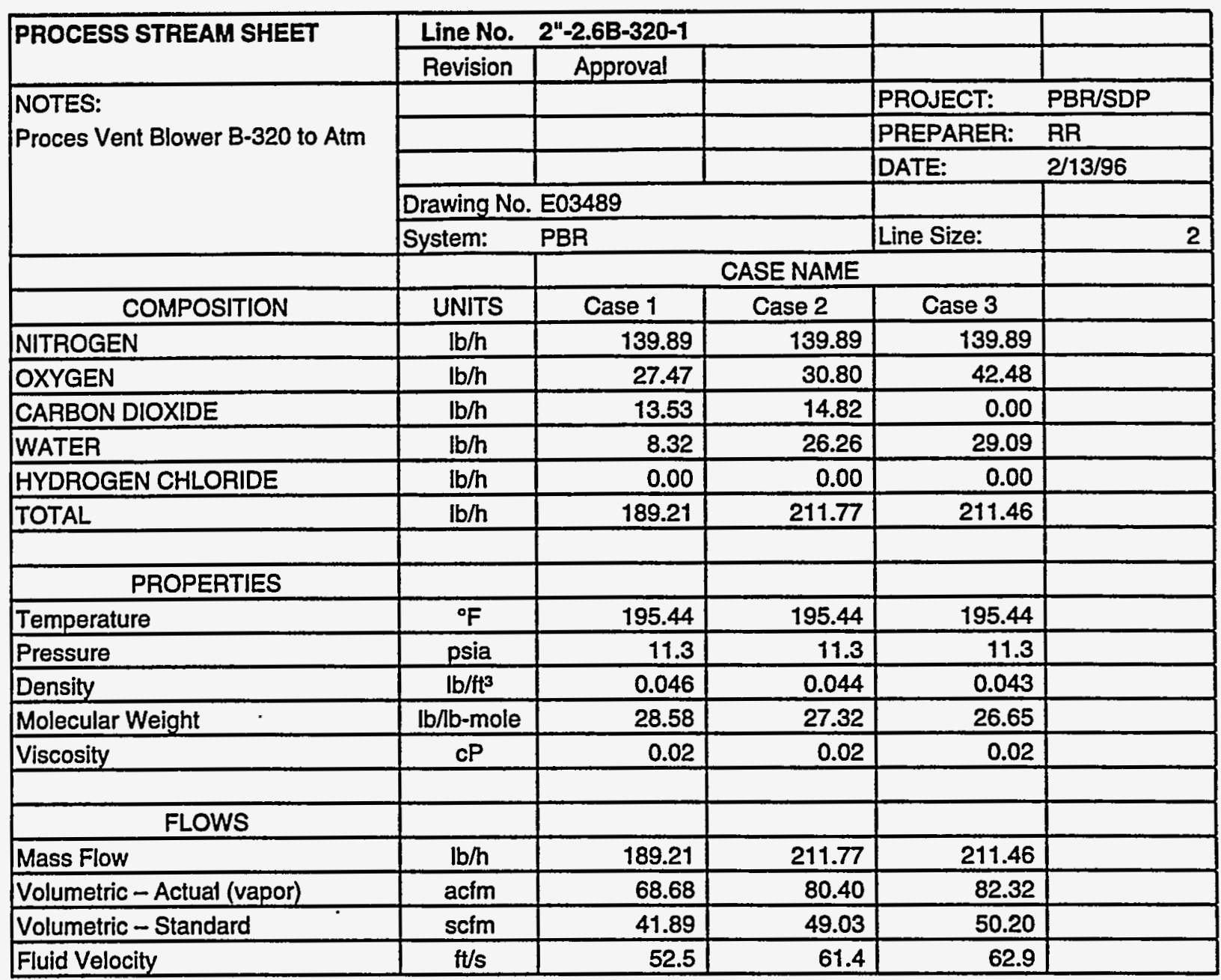


Table D-2 (continued). Stream Sheets

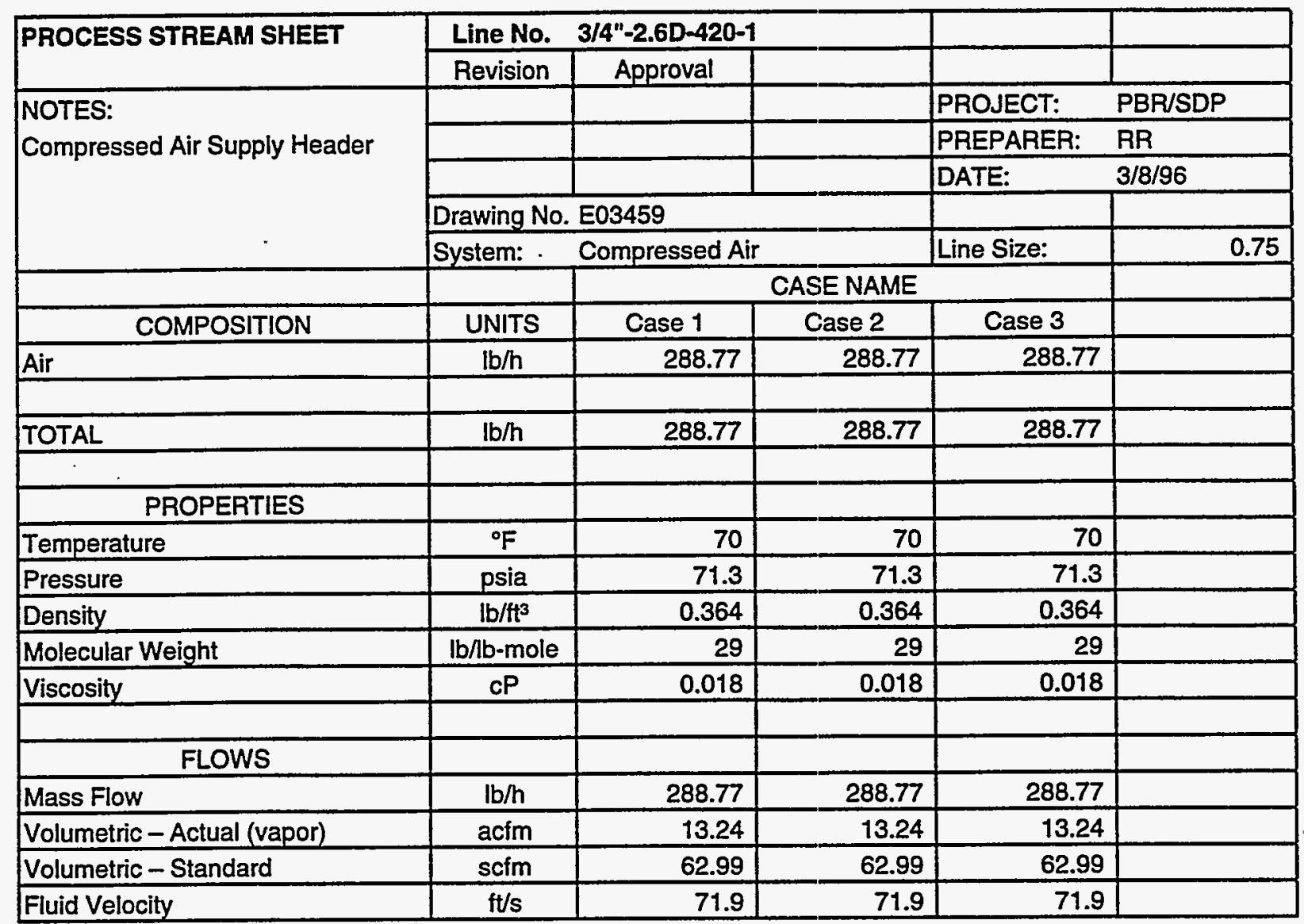


Table D-2 (continued). Stream Sheets

\begin{tabular}{|c|c|c|c|c|c|}
\hline \multirow[t]{2}{*}{ PROCESS STREAM SHEET } & \multicolumn{3}{|c|}{ Line No. 1/2"-2.6D-420-02 } & & \\
\hline & Revision & \begin{tabular}{|l|} 
Approval \\
\end{tabular} & & & \\
\hline \multirow{6}{*}{$\begin{array}{l}\text { NOTES: } \\
\text { Air to Agitator A-010 }\end{array}$} & & & & PROJECT: & PBR/SDP \\
\hline & & & & PREPARER: & $\mathrm{RR}$ \\
\hline & & & & DATE: & $3 / 8 / 96$ \\
\hline & \multicolumn{3}{|c|}{ Drawing No. E03456, E03459 } & & \\
\hline & System: & \multicolumn{2}{|c|}{ Waste Feed Tank } & Line Size: & 0.5 \\
\hline & $\cdot$ & \multicolumn{3}{|c|}{ CASE NAME } & \\
\hline COMPOSITION & UNITS & Case 1 & Case 2 & Case 3 & \\
\hline Air & $\mathrm{lb} / \mathrm{h}$ & 68.75 & 68.75 & 68.75 & \\
\hline TOTAL & $\mathrm{lb} / \mathrm{h}$ & 68.75 & 68.75 & 68.75 & \\
\hline \multirow{2}{*}{\multicolumn{6}{|c|}{ PROPERTIES }} \\
\hline & & & & & \\
\hline Temperature & ${ }^{\circ} \mathrm{F}$ & 70 & 70 & 70 & \\
\hline Pressure & psia & 71.3 & 71.3 & 71.3 & \\
\hline Density & $\mathrm{lb} / \mathrm{ft}^{3}$ & 0.364 & 0.364 & 0.364 & \\
\hline Molecular Weight & $\mathrm{lb} / \mathrm{lb}-\mathrm{mole}$ & 29 & 29 & 29 & \\
\hline Viscosity & $\mathrm{cP}$ & 0.018 & 0.018 & 0.018 & \\
\hline \multicolumn{6}{|l|}{ FLOWS } \\
\hline Mass Flow & $\mathrm{lb} / \mathrm{h}$ & 68.75 & 68.75 & 68.75 & \\
\hline Volumetric - Actual (vapor) & acfm & 3.15 & 3.15 & 3.15 & \\
\hline Volumetric - Standard & scfm & 15.00 & 15.00 & 15.00 & \\
\hline Fluid Velocity & $\mathrm{ft} / \mathrm{s}$ & 38.5 & 38.5 & 38.5 & \\
\hline
\end{tabular}


Table D-2 (continued). Stream Sheets

\begin{tabular}{|c|c|c|c|c|c|}
\hline \multirow[t]{2}{*}{ PROCESS STREAM SHEET } & \multicolumn{3}{|c|}{ Line No. $\quad 3 / 8 "-2.6 D-420-03$} & & \\
\hline & Revision & Approval & & & \\
\hline \multirow{6}{*}{$\begin{array}{l}\text { NOTES: } \\
\text { Air to Waste Transfer Pump } \\
\text { P-002 }\end{array}$} & & & & PROJECT: & PBR/SDP \\
\hline & & & & PREPARER: & RR \\
\hline & & & & DATE: & $3 / 8 / 96$ \\
\hline & \multicolumn{3}{|c|}{ Drawing No. E03456, E03459 } & & \\
\hline & \multirow[t]{2}{*}{ System: - } & \multicolumn{2}{|c|}{ Waste Feed Tank } & Line Size: & 0.375 \\
\hline & & \multicolumn{3}{|c|}{ CASE NAME } & \\
\hline COMPOSITION & UNITS & Case 1 & Case 2 & Case 3 & \\
\hline Air & $\mathrm{lb} / \mathrm{h}$ & 36.67 & 36.67 & 36.67 & \\
\hline TOTAL & $\mathrm{lb} / \mathrm{h}$ & 36.67 & 36.67 & 36.67 & \\
\hline & & & & & \\
\hline \multicolumn{6}{|l|}{ PROPERTIES } \\
\hline Temperature & ${ }^{\circ} \mathrm{F}$ & 70 & 70 & 70 & \\
\hline Pressure & psia & 71.3 & 71.3 & 71.3 & \\
\hline Density & $\mathrm{lb} / \mathrm{ft}^{3}$ & 0.364 & 0.364 & 0.364 & \\
\hline Molecular Weight & $\mathrm{lb} / \mathrm{b}$-mole & 29 & 29 & 29 & \\
\hline Viscosity & $\mathrm{CP}$ & 0.018 & 0.018 & 0.018 & \\
\hline & & & & & \\
\hline \multicolumn{6}{|l|}{ FLOWS } \\
\hline Mass Flow & $\mathrm{lb} / \mathrm{h}$ & 36.67 & 36.67 & 36.67 & \\
\hline Volumetric - Actual (vapor) & acim & 1.68 & 1.68 & 1.68 & \\
\hline Volumetric - Standard & scfm & 8.00 & 8.00 & 8.00 & \\
\hline Fluid Velocity & $\mathrm{ft} / \mathrm{s}$ & 20.5 & 20.5 & 20.5 & \\
\hline
\end{tabular}




\begin{tabular}{|c|c|c|c|c|c|}
\hline \multirow[t]{2}{*}{ PROCESS STREAM SHEET } & \multicolumn{3}{|c|}{ Line No. $\quad 1 / 2^{\prime \prime}-2.6 \mathrm{D}-450-1$} & & \\
\hline & Revision & Approval & & & \multirow[b]{2}{*}{ PBR/SDP } \\
\hline \multirow{6}{*}{$\begin{array}{l}\text { NOTES: } \\
\text { Nitrogen Pad to T-010 } \\
\text { Based on } 15 \mathrm{gal} / \mathrm{d} \text { for Case } 1 \text { and } 2 \\
75 \mathrm{gal} / \mathrm{d} \text { for Case } 3\end{array}$} & & & & PROJECT: & \\
\hline & & & & PREPARER: & RR \\
\hline & & & & DATE: & $3 / 8 / 96$ \\
\hline & \multicolumn{3}{|c|}{ Drawing No. E03456, E03459 } & & \\
\hline & System: & Nitrogen & & Line Size: & 0.5 \\
\hline & \multicolumn{4}{|c|}{ CASE NAME } & \\
\hline \multirow{2}{*}{\begin{tabular}{|l} 
COMPOSITION \\
Nitrogen
\end{tabular}} & UNITS & Case 1 & Case 2 & Case 3 & \\
\hline & $\mathrm{lb} / \mathrm{h}$ & 0.006 & 0.006 & 0.030 & \\
\hline \multirow[t]{2}{*}{ TOTAL } & $\mathrm{lb} / \mathrm{h}$ & 0.006 & 0.006 & \multirow[t]{2}{*}{0.030} & \\
\hline & & & & & \\
\hline \multicolumn{6}{|l|}{ PROPERTIES } \\
\hline Temperature & ${ }^{\circ} \mathrm{F}$ & 70 & 70 & 70 & \\
\hline Pressure & psia & 71.3 & 71.3 & \multirow{2}{*}{$\begin{array}{r}71.3 \\
0351\end{array}$} & \\
\hline Density & $\mathrm{lb} / \mathrm{ft}^{3}$ & 0.351 & 0.351 & & \\
\hline Molecular Weight & lb/lb-mole & 28.013 & 28.013 & $\begin{array}{r}0.351 \\
28.013\end{array}$ & \\
\hline Viscosity & cP & 0.018 & 0.018 & $\frac{20.010}{0.018}$ & \\
\hline \multicolumn{5}{|l|}{ FLOWS } & \\
\hline Mass Flow & $\mathrm{lb} / \mathrm{h}$ & 0.0060 & 0.0060 & 0.0302 & \\
\hline Volumetric - Actual (vapor) & acfm & 0.0003 & 0.0003 & 0.0014 & \\
\hline Volumetric - Standard & scfm & 0.0014 & 0.0014 & 0.0070 & \\
\hline Fluid Velocity & $\mathrm{ft} / \mathrm{s}$ & 0.0035 & 0.0035 & 0.0175 & \\
\hline
\end{tabular}




\begin{tabular}{|c|c|c|c|c|c|}
\hline \multirow[t]{2}{*}{ PROCESS STREAM SHEET } & \multicolumn{3}{|c|}{ Line No. $1 / 2 "-2.6 D-450-2$} & & \\
\hline & Revision & Approval & & & \\
\hline \multirow{6}{*}{$\begin{array}{l}\text { NOTES: } \\
\text { Nitrogen Sweep to Relief Header } \\
\text { Based on } 1 \mathrm{scfm}\end{array}$} & & & & PROJECT: & PBR/SDP \\
\hline & & & & PREPARER: & $\mathrm{RA}$ \\
\hline & & & & DATE: & $3 / 8 / 96$ \\
\hline & \multicolumn{3}{|c|}{ Drawing No. E03456, E03459 } & & \\
\hline & System: & Nitrogen & & Line Size: & 0.5 \\
\hline & & \multicolumn{3}{|c|}{ CASE NAME } & \\
\hline COMPOSITION & UNITS & Case 1 & Case 2 & Case 3 & \\
\hline \multirow[t]{2}{*}{ Nitrogen } & $\mathrm{lb} / \mathrm{h}$ & 4.345 & 4.345 & 4.345 & \\
\hline & & \pm & & & \\
\hline \multirow[t]{2}{*}{ TOTAL } & $\mathrm{lb} / \mathrm{h}$ & 4.345 & 4.345 & 4.345 & \\
\hline & & & & & \\
\hline \multicolumn{6}{|l|}{\begin{tabular}{|l} 
PROPERTIES \\
\end{tabular}} \\
\hline Temperature & ${ }^{\circ} \mathrm{F}$ & 70 & 70 & 70 & \\
\hline Pressure & psia & 71.3 & 71.3 & 71.3 & \\
\hline Density & $\mathrm{lb} / \mathrm{tt}^{3}$ & 0.351 & 0.351 & 0.351 & \\
\hline Molecular Weight & $\mathrm{lb} / \mathrm{b}$-mole & 28.013 & 28.013 & 28.013 & \\
\hline Viscosity & $C P$ & 0.018 & 0.018 & 0.018 & \\
\hline \multicolumn{6}{|l|}{ FLOWS } \\
\hline Mass Flow & $\mathrm{lb} / \mathrm{h}$ & 4.345 & 4.345 & 4.345 & \\
\hline Volumetric - Actual (vapor) & $\mathrm{acfm}$ & 0.206 & 0.206 & 0.206 & \\
\hline Volumetric - Standard & scfm & 1 & 1 & 1 & \\
\hline Fluid Velocity & $\mathrm{ft} / \mathrm{s}$ & 2.520 & 2.520 & 2.520 & \\
\hline
\end{tabular}

\section{DISCLAIMER}

This report was prepared as an account of work sponsored by an agency of the United States Government. Neither the United States Government nor any agency thereof, nor any of their employees, makes any warranty, express or implied, or assumes any legal liability or responsibility for the accuracy, completeness, or usefulness of any information, apparatus, product, or process disclosed, or represents that its use would not infringe privately owned rights. Reference herein to any specific commercial product, process, or service by trade name, trademark, manufacturer, or otherwise does not necessarily constitute or imply its endorsement, recommendation, or favoring by the United States Government or any agency thereof. The views and opinions of authors expressed herein do not necessarily state or reflect those of the United States Government or any agency thereof.- 